\title{
TOXECONTM RETROFIT FOR MERCURY AND MULTI-POLLUTANT CONTROL ON THREE 90-MW COAL-FIRED BOILERS
}

Quarterly Technical Progress Report

Reporting Period: January 1, 2006 - March 31, 2006

Report No. 41766R08

\author{
Prepared by \\ Steven T. Derenne \\ Wisconsin Electric Power Company \\ 333 West Everett Street \\ Milwaukee, WI 53203
}

April 28, 2006

DOE Cooperative Agreement No. DE-FC26-04NT41766

Theodore J. McMahon

USDOE Contracting Officer's Representative 


\section{DISCLAIMER}

This report was prepared as an account of work sponsored by an agency of the United States Government. Neither the United States Government nor any agency thereof, nor any of their employees, makes any warranty, express or implied, or assumes any legal liability or responsibility for the accuracy, completeness, or usefulness of any information, apparatus, product, or process disclosed, or represents that its use would not infringe privately owned rights. Reference herein to any specific commercial product, process, or service by trade name trademark, manufacturer, or otherwise does not necessarily constitute or imply its endorsement, recommendation, or favoring by the United States Government or any agency thereof. The views and opinions of authors expressed herein do not necessarily state or reflect those of the United States Government or any agency thereof. 


\section{ABSTRACT}

With the Nation's coal-burning utilities facing tighter controls on mercury pollutants, the U.S. Department of Energy is supporting projects that could offer power plant operators better ways to reduce these emissions at much lower costs. Sorbent injection technology represents one of the simplest and most mature approaches to controlling mercury emissions from coalfired boilers. It involves injecting a solid material such as powdered activated carbon into the flue gas. The gas-phase mercury in the flue gas contacts the sorbent and attaches to its surface. The sorbent with the mercury attached is then collected by a particulate control device along with the other solid material, primarily fly ash.

We Energies has over 3,200 MW of coal-fired generating capacity and supports an integrated multi-emission control strategy for $\mathrm{SO}_{2}, \mathrm{NO}_{\mathrm{x}}$, and mercury emissions while maintaining a varied fuel mix for electric supply. The primary goal of this project is to reduce mercury emissions from three 90-MW units that burn Powder River Basin coal at the We Energies Presque Isle Power Plant. Additional goals are to reduce nitrogen oxide $\left(\mathrm{NO}_{\mathrm{x}}\right)$, sulfur dioxide $\left(\mathrm{SO}_{2}\right)$, and particulate matter (PM) emissions, allow for reuse and sale of fly ash, demonstrate a reliable mercury continuous emission monitor (CEM) suitable for use in the power plant environment, and demonstrate a process to recover mercury captured in the sorbent. To achieve these goals, We Energies (the Participant) will design, install, and operate a TOXECON ${ }^{\mathrm{TM}}$ system designed to clean the combined flue gases of Units 7, 8, and 9 at the Presque Isle Power Plant.

TOXECON ${ }^{\mathrm{TM}}$ is a patented process in which a fabric filter system (baghouse) installed downstream of an existing particle control device is used in conjunction with sorbent injection for removal of pollutants from combustion flue gas. For this project, the flue gas emissions will be controlled from the three units using a single baghouse. Mercury will be controlled by injection of activated carbon or other novel sorbents, while $\mathrm{NO}_{\mathrm{x}}$ and $\mathrm{SO}_{2}$ will be controlled by injection of sodium-based or other novel sorbents. Addition of the TOXECONTM baghouse will provide enhanced particulate control. Sorbents will be injected downstream of the existing particle collection device to allow for continued sale and reuse of captured fly ash from the existing particulate control device, uncontaminated by activated carbon or sodium sorbents.

Methods for sorbent regeneration, i.e., mercury recovery from the sorbent, will be explored and evaluated. For mercury concentration monitoring in the flue gas streams, components available for use will be evaluated and the best available will be integrated into a mercury CEM suitable for use in the power plant environment. This project will provide for the use of a control system to reduce emissions of mercury while minimizing waste from a coal-fired power generation system. 


\section{TABLE OF CONTENTS}

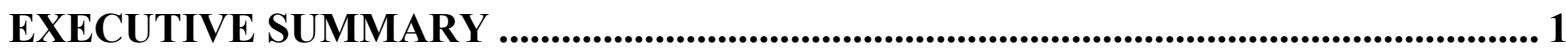

INTRODUCTION............................................................................................................ 2

Project Objectives ......................................................................................................................... 2

Scope of Project....................................................................................................................... 2

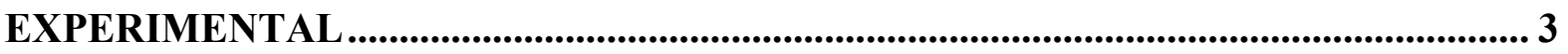

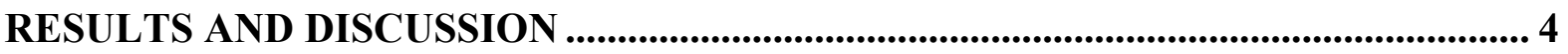

Task 1 - Design Review Meeting ........................................................................................... 4

Task 2 - Project Management Plan ............................................................................................ 4

Task 3 - Provide NEPA Documentation, Environmental Approvals

Documentation, and Regulatory Approval Documentation ................................. 4

Task 4 - Balance of Plant (BOP) Engineering .................................................................. 4

Task 5 - Process Equipment Design and Major Equipment Procurement................... 4

Task 6 - Prepare Construction Plan ...................................................................................... 4

Task 7 - Procure Mercury Continuous Emission Monitor (CEM) Package and Perform Engineering and Performance Assessment..................................... 4

CEM Update .......................................................................................................................5

Site Progress ..................................................................................................................................

Task 8 - Mobilize Contractors..................................................................................... 6

Task 9 - Foundation Erection.............................................................................................. 6

Task 10 - Erect Structural Steel, Baghouse and Ductwork............................................. 6

Task 11 - Balance of Plant Mechanical and Civil/Structural Installations.................. 6

Task 12 - Balance of Plant Electrical Installations........................................................ 6

Task 13 - Equipment Pre-Operational Testing ....................................................................... 7

Task 14 - Start-Up and Operator Training ...................................................................... 7

PAC System Checkout.......................................................................................................

Task 15 - Operate, Test, Data Analysis and Optimize TOXECON'M for

Mercury Control ......................................................................................................... 9

Baseline Tests (February 13 - February 16) …………………………………………....10

Parametric Testing (February 20 - March 1) .............................................................15

Overheating of PAC/Ash in Baghouse Hoppers ...........................................................21

Mercury Quality Index Test ............................................................................................34

Task 16 - Operate, Test, Data Analysis and Optimize TOXECON'M for $\mathrm{NO}_{\mathrm{x}}$

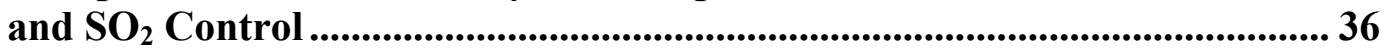

Task 17 - Carbon - Ash Management System.................................................................... 36

Task 18 - Revise Design Specifications, Prepare O\&M Manuals................................... 36

Task 19 - Reporting, Management, Subcontracts, Technology Transfer ................... 36

Activity during the Quarter ...........................................................................................36

CONCLUSION _.................................................................................................................................. 37

DOE Report No. 41766R08 $\quad$ iii 


\section{List of Figures}

Figure 1. Sketch of Mercury CEM Integration into DAS and DCS. ..............................5

Figure 2. Inlet and outlet mercury concentrations and baghouse pressure drop, January

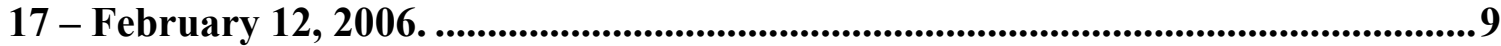

Figure 3. Baghouse Temperature Profile...........................................................................10

Figure 4. Thermo CEM and Ontario Hydro Measurements .............................................. 12

Figure 5. Inlet and outlet mercury concentrations and baghouse pressure and

temperature, February 13 - February 17, 2006......................................................... 14

Figure 6. Inlet and outlet mercury concentrations and baghouse pressure drop,

February 16 - February 21, 2006.

Figure 7. Inlet and outlet mercury concentrations, carbon injection concentration, baghouse pressure drop, inlet temperature and removal February 20 - March 1, 2006.

Figure 8. Linear regression showing relationship between inlet temperature and mercury removal efficiency and +/- $5 \%$ band.......................................................19

Figure 9. Inlet Temperature and Outlet Mercury Concentration. ...................................20

Figure 10. Combustion Temperature Comparison of PAC and PAC/ash ........................23

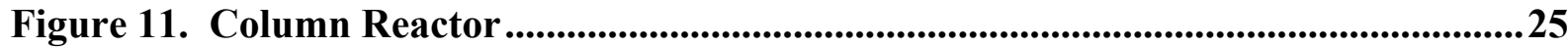

Figure 12. Column Test - PAC with Air at Ambient Temperature. ..................................26

Figure 13. Column Test - PAC with Air at Flue Gas Temperature................................27

Figure 14. Column Test - PAC with Simulated Flue Gas ................................................27

Figure 15. Baghouse Temperature Comparison ...................................................................28

Figure 16. Precipitate in Compartment \#1 .....................................................................30

Figure 17. Close-up of Precipitate from Compartment \#1 .....................................................31

Figure 18. Interior Wall j-tubes in Compartment \#1 .........................................................31

Figure 19. Thermocouples for PAC Bed ..............................................................................32

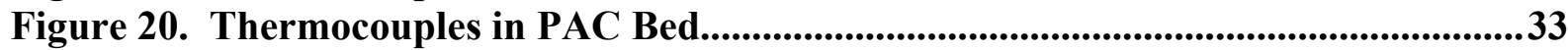

Figure 21. PAC Hopper Test - Inside Wall Temperatures ..............................................33

Figure 22. PAC Hopper Test - PAC Bed Temperatures ...........................................................34

Figure 23. Mercury Quality Index Test Apparatus..............................................................35

DOE Report No. 41766R08 iv 


\section{List of Tables}

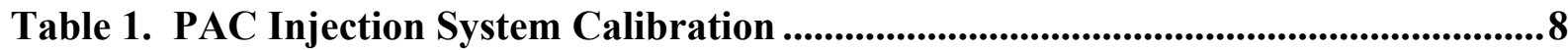

Table 2. Flue Gas Temperature Comparison..................................................................11

Table 3. Particulate Removal across the Baghouse ...................................................11

Table 4. Hydrogen Halide and Halogen Measurements..................................................11

Table 5. Comparison of Thermo CEM and Ontario Hydro Data ......................................... 12

Table 6. Method 324 Results ................................................................................................13

Table 7. Coal and Ash Sampling Schedule - Baseline ............................................................. 14

Table 8. Coal and Ash Analysis Schedule - Baseline ................................................15

Table 9. Coal and Ash Results - Baseline ..........................................................................15

Table 10. Parametric Test Conditions with DARCO Hg .......................................................16

Table 11. Operation Log During Parametric Tests ........................................................17

Table 12. Results from Parametric Tests with DARCO Hg .......................................20

Table 13. Coal and Ash Sampling Schedule - Parametric....................................................21

Table 14. Temperature Comparisons on PAC and PAC/ash Mixtures ...........................24

Table 15. Column Reactor Tests.....................................................................................26

Table 16. Simulated Flue Gas Composition ..........................................................................26

Table 17. Comparison of Presque Isle and Plant Gaston............................................29

DOE Report No. 41766R08 $\quad$ v 


\section{EXECUTIVE SUMMARY}

Wisconsin Electric Power Company (We Energies) signed a Cooperative Agreement with the U.S. Department of Energy (DOE) in March 2004 to fully demonstrate TOXECON ${ }^{\mathrm{TM}}$ for mercury control at the We Energies Presque Isle Power Plant. The primary goal of this project is to reduce mercury emissions from three 90-MW units (Units 7, 8, and 9) that burn Powder River Basin (PRB) coal. Additional goals are to reduce nitrogen oxide $\left(\mathrm{NO}_{\mathrm{x}}\right)$, sulfur dioxide $\left(\mathrm{SO}_{2}\right)$, and particulate matter (PM) emissions, allow for reuse and sale of fly ash, demonstrate a reliable mercury continuous emission monitor (CEM) suitable for use in the power plant environment, and demonstrate a process to recover mercury captured in the sorbent.

We Energies has teamed with ADA-ES, Inc., (ADA-ES) and Cummins \& Barnard, Inc., $(\mathrm{C} \& \mathrm{~B})$ to execute this project. ADA-ES is providing engineering and management on the mercury measurement and control systems. Cummins \& Barnard is the engineer of record and will be responsible for construction, management, and start-up of the TOXECONTM equipment.

This project was selected for negotiating an award in January 2003. Preliminary activities covered under the "Pre-Award" provision in the Cooperative Agreement began in March 2003. This quarterly report summarizes progress made on the project from January 1, 2006, through March 31, 2006. During this reporting period, work was conducted on the following tasks:

Task 7. Procure Mercury Continuous Emissions Monitor (CEM) Package and Perform Engineering and Performance Assessment.

Task 10. Erect Structural Steel, Baghouse, and Ductwork.

Task 13. Equipment Pre-Operational Testing.

Task 14. Start Up and Operator Training.

Task 15. Operate, Test, Data Analysis, and Optimize TOXECONTM for Mercury Control.

Task 19. Reporting, Management, Subcontracts, Technology Transfer. 


\section{INTRODUCTION}

DOE awarded Cooperative Agreement No. DE-FC26-04NT41766 to We Energies to demonstrate TOXECON ${ }^{\mathrm{TM}}$ for mercury and multi-pollutant control, a reliable mercury continuous emission monitor (CEM), and a process to recover mercury captured in the sorbent. Under this agreement, We Energies is working in partnership with the DOE.

Quarterly reports will provide project progress, results from technology demonstrations, and technology transfer information.

\section{Project Objectives}

The specific objectives of this project are to demonstrate the operation of the TOXECONTM multi-pollutant control system and accessories, and

- Achieve $90 \%$ mercury removal from flue gas through activated carbon injection

- Evaluate the potential for $70 \% \mathrm{SO}_{2}$ control and trim control of $\mathrm{NO}_{\mathrm{x}}$ from flue gas through sodium-based or other novel sorbent injection

- Reduce PM emission through collection by the TOXECONTM baghouse

- Recover $90 \%$ of the mercury captured in the sorbent

- Utilize $100 \%$ of fly ash collected in the existing electrostatic precipitator

- Demonstrate a reliable, accurate mercury CEM suitable for use in the power plant environment

- Successfully integrate and optimize TOXECON ${ }^{\mathrm{TM}}$ system operation for mercury and multi-pollutant control

\section{Scope of Project}

The "TOXECON" Retrofit for Mercury and Multi-Pollutant Control on Three 90-MW CoalFired Boilers" project will be completed in two Budget Periods. These two Budget Periods are:

Budget Period 1: Project Definition, Design and Engineering, Prototype Testing, Major Equipment Procurement, and Foundation Installation. Budget Period 1 initiated the project with project definition activities including NEPA, followed by design, which included specification and procurement of long lead-time major equipment, and installation of foundations. In addition, testing of prototype mercury CEMs was conducted. Activities under Budget Period 1 were completed during 1Q05.

Budget Period 2: CEM Demonstration, TOXECON ${ }^{\mathrm{TM}}$ Erection, TOXECONTM Operation, and Carbon Ash Management Demonstration. In Budget Period 2, the TOXECON ${ }^{\mathrm{TM}}$ system will be constructed and operated. Operation will include optimization for mercury control, parametric testing for $\mathrm{SO}_{2}$ and $\mathrm{NO}_{\mathrm{x}}$ control, and long-term testing for mercury control. The 
mercury CEM and sorbent regeneration processes will be demonstrated in conjunction with the TOXECON ${ }^{\mathrm{TM}}$ system operation.

The project continues to move through Budget Period 2 as of the current reporting period. Each task is described in the Statement of Project Objectives (SOPO) that is part of the Cooperative Agreement.

\section{EXPERIMENTAL}

None to report. 


\section{RESULTS AND DISCUSSION}

Following are descriptions of the work performed on project tasks during this reporting period.

\section{Task 1 - Design Review Meeting}

Work associated with this task was previously completed.

\section{Task 2 - Project Management Plan}

Work associated with this task was previously completed.

\section{Task 3 - Provide NEPA Documentation, Environmental Approvals Documentation, and Regulatory Approval Documentation}

Work associated with this task was previously completed.

\section{Task 4 - Balance of Plant (BOP) Engineering}

Work associated with this task was completed during 1Q05 in Budget Period 1.

\section{Task 5 - Process Equipment Design and Major Equipment Procurement}

Work associated with this task was completed during 1Q05 in Budget Period 1.

\section{Task 6 - Prepare Construction Plan}

Work associated with this task was completed during 1Q05 in Budget Period 1. The Construction Plan was issued on January 26, 2005.

\section{Task 7 - Procure Mercury Continuous Emission Monitor (CEM) Package and Perform Engineering and Performance Assessment}

The overall goal of this task is to have a compliance-grade, reliable, certified mercury CEM installed and operational for use in the TOXECONTM evaluation. ADA-ES has teamed with Thermo Electron Corporation on this task. The Thermo Electron CEM was described in detail in a previous Quarterly Report (DOE Report No. 41766R05). 


\section{CEM Update}

Several activities were completed this quarter:

- Successful operation of the two commercial, i-series mercury CEMs at the inlet and outlet of the baghouse. The inlet analyzer is sampling from the duct at the outlet of Unit 8 air preheater.

- Integration of the two CEMs with an ESC data logger and the plant DCS system.

\section{Site Progress}

On June 30, 2005, a beta version (c-series) Thermo Electron CEM was installed at the outlet of the air preheater on Unit 8. Two new i-series Mercury Freedom ${ }^{\mathrm{TM}}$ CEMs were installed in December 2005, one replacing the beta CEM and one at the outlet duct of the baghouse. Data from the two CEMs are shown in Task 15 as part of the TOXECONTM testing.

During the week of January 10, 2006, the inlet and outlet mercury CEMs were integrated into the plant DAS and DCS system. A sketch showing the primary connections is shown in Figure 1. The mercury CEMs are connected through an ESC datalogger that controls the daily zero and span checks on the same schedule as the other plant CEMs. Mercury concentrations and status information is stored on the plant DAS with other plant CEM data. The mercury concentration output from the mercury CEM was also connected directly into the plant DCS system to allow feedback control of the sorbent injection system in the future.

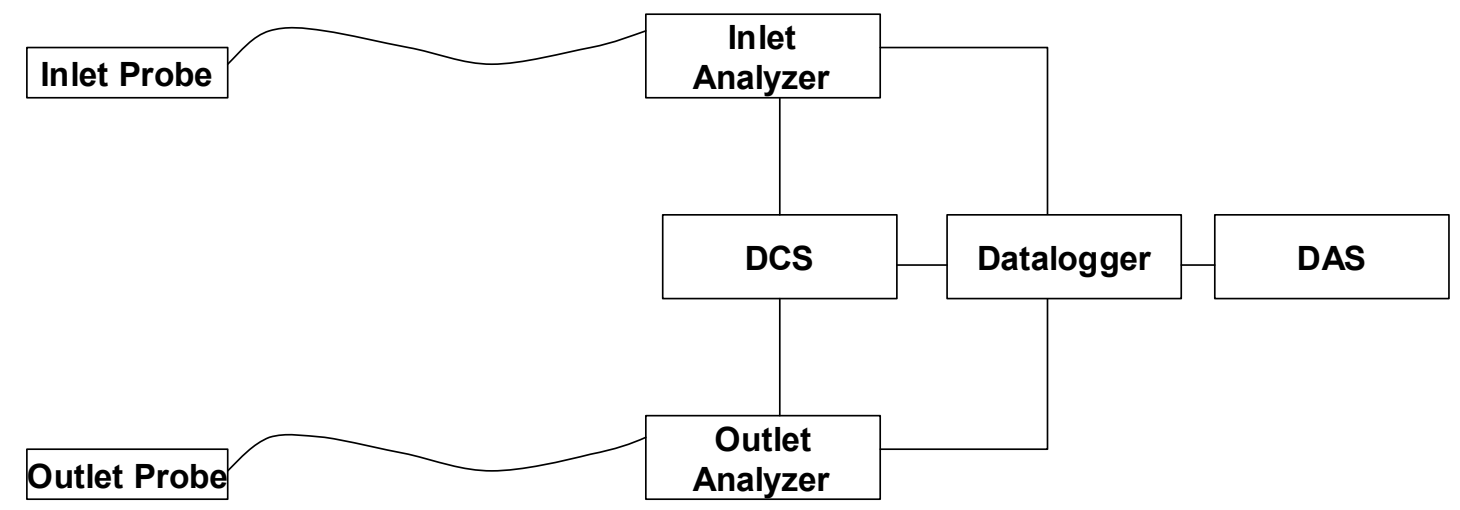

DCS: Process Control

$\mathrm{Hg}$ concentration from CEM

Average concentration and emission rate with data validation from datalogger

DAS: "Compliance" Record

Figure 1. Sketch of Mercury CEM Integration into DAS and DCS.

On January 24, the hot lines were installed for sampling mercury from Units 7 and 9. The tie-in will be the same as currently installed on Unit 8 . Two corresponding penetrations into 
the inlet CEM shelter were installed to accommodate these hot lines. The probes for these hot lines are scheduled to be installed in 2Q06.

Both mercury CEMs are calibrated daily and records of the zero checks, span checks, and calibrations are recorded. A summary of this data with a discussion of CEM operation will be included in the second quarter 2006 report.

\section{Task 8 - Mobilize Contractors}

Contractor mobilization was completed in 2Q05.

During this period, the remainder of CaTS personnel completed their assignments and CaTS Construction Management Team demobilized from the site.

Jamar, Boldt, Northland Electric, United Anco, PCI, Wheelabrator and CaTS demobilized from the site in $4 \mathrm{Q} 05$.

\section{Task 9 - Foundation Erection}

All Major foundation work by Boldt Construction Co. was completed during 1Q05.

\section{Task 10 - Erect Structural Steel, Baghouse and Ductwork}

The erection work associated with task was initiated during 2Q05.

The work effort for this task during the 1st quarter of 2006 was limited to final exception/punch list item work, with the exception of final insulation/lagging installation. Some minor access platform work to address exception/punch list items was also initiated during this quarter. Other items included contractor demobilization, final cleanup and Construction Management Team demobilization.

\section{Task 11 - Balance of Plant Mechanical and Civil/Structural Installations}

Primary work associated with this task was completed in 4Q05. Exception/punch list item completion was the primary focus during 1Q06.

\section{Task 12 - Balance of Plant Electrical Installations}

Primary work associated with this task was completed in 4Q05. Exception/punch list item completion was the primary focus during 1Q06. 


\section{Task 13 - Equipment Pre-Operational Testing}

Pre-operational testing was completed in 4Q05.

\section{Task 14 - Start-Up and Operator Training}

Startup of all major equipment was completed in 4Q05. Final O\&M manuals were received for most major equipment in 2005.

The operator training program was completed during 4Q05 to train the plant operations personnel.

The baghouse was initially brought into operation on December 17 with flue gas from Unit 7. Initial operation with Unit 8 occurred on January 5, 2006 and Unit 9 on January 27, 2006.

\section{PAC System Checkout}

A meeting was held in January with We Energies and ADA-ES to discuss PAC injection control strategies. Based on the meeting, the plant is developing the following five control strategies:

- Constant Rate Injection

- Feedback w/ Hg removal efficiency as a setpoint.

- Feedback w/ Hg outlet as a setpoint.

- Feedback w/ Hg inlet as a setpoint.

- Batch Injection - this strategy is in its infant stages and will be developed over time.

The PAC silo and injection system was started and checked in January 2006. PAC was delivered 10:30 am Thursday, January 26. There was no sign of leakage from the silo during or after transport of PAC from the truck to the silo. The vent filter worked well.

The PAC injection system checkout included the following:

- Bumped all motors and checked for proper rotation.

- Meggered all (6) 480 VAC motors.

- Started all (3) injection trains on the PAC System (i.e., Unit 7, 8, 9). Calibrated all (3) trains and the maximum feed rate for each of the trains were $190 \mathrm{lb} / \mathrm{hr}, 190 \mathrm{lb} / \mathrm{hr}$ and $220 \mathrm{lb} / \mathrm{hr}$. The difference in maximum feed rate may be attributed to material flow characteristics at the time.

- Tested the maximum conveying rates for all (3) injection trains. With the existing metering augers, the maximum injection rate was $100 \%$ of the feeder speed. The eductor is sized such that, the plant should have no problem feeding between $5-100 \%$ of the feeder demand.

The first PAC injection started on January 27 at 2:35 pm. This was injection only into Unit 7 duct. The injection continued until 6:30 pm at varying injection rates. There was no noticeable increase in pressure drop in the baghouse during injection. The outlet mercury concentration went from $5.0 \mathrm{ug} / \mathrm{m}^{3}$ to $2.1 \mathrm{ug} / \mathrm{m}^{3}$. 
PAC injection was started at 9:45 am on January 28. All three injection trains were used. Each unit was brought up to $100 \%$ feed rate while the other two were kept at $10 \%$. After this, the PAC injection was kept at 10\% on all three trains. Injection stopped at 11:30 am and resumed at 12:45 pm. The injection rate in the afternoon was $10 \%$ in each train.

The PAC feeders were calibrated on January 28. Table 1 shows that they were injecting less than originally calculated. The new calibration factors to convert percent feeder speed to actual feed rates were changed in the DCS logic.

\section{Table 1. PAC Injection System Calibration}

\begin{tabular}{|l|l|l|l|l|l|l|}
\hline Unit & $\begin{array}{l}\text { Feed } \\
\text { Rate } \\
\mathbf{( \% )}\end{array}$ & $\begin{array}{l}\text { Assumed } \\
\text { Feed Rate } \\
\text { (lb/hr) }\end{array}$ & $\begin{array}{l}\text { Sample } \\
\text { Weight } \\
\text { (lb) }\end{array}$ & $\begin{array}{l}\text { Sample Time } \\
\text { (min) }\end{array}$ & $\begin{array}{l}\text { Actual Feed } \\
\text { Rate (lb/hr) }\end{array}$ & $\begin{array}{l}\text { Differential } \\
\mathbf{( \% )}\end{array}$ \\
\hline 7 & 5 & 15 & 1.375 & 10 & 8.25 & 55.00 \\
\hline 7 & 10 & 30 & 3.125 & 10 & 18.75 & 62.50 \\
\hline 7 & 20 & 60 & 7.625 & 5 & 37.50 & 62.50 \\
\hline 7 & 50 & 150 & 8.250 & 5 & 99.00 & 66.00 \\
\hline 7 & 75 & 225 & 7.500 & 3 & 150.00 & 66.67 \\
\hline 8 & 10 & 30 & 3.250 & 10 & 19.50 & 65.00 \\
\hline 8 & 20 & 60 & 3.750 & 6 & 37.50 & 62.50 \\
\hline 8 & 50 & 150 & 5.000 & 3 & 100.00 & 66.67 \\
\hline 9 & 10 & 30 & 4.000 & 10 & 24.00 & 80.00 \\
\hline 9 & 20 & 60 & 4.375 & 6 & 43.75 & 72.92 \\
\hline 9 & 50 & 150 & 5.625 & 3 & 112.50 & 75.00 \\
\hline
\end{tabular}




\section{Task 15 - Operate, Test, Data Analysis and Optimize TOXECONTM for Mercury Control}

On December 17, the baghouse was put into service with flue gas from Unit 7. Unit 9 was added on January 5 and Unit 8 on January 27, 2006.

TOXECON ${ }^{\mathrm{TM}}$ testing officially began after check out of the PAC system. Figure 2 shows tube sheet pressure drop for all ten compartments and inlet and outlet mercury concentrations for the time period covering PAC startup and up to baseline testing. The data shows mercury removal during PAC startup and cycling of the PAC feeders as the system was checked out. The data also show that tube sheet pressure drop increases by over a half inch W.C. from the front compartments ( 1 and 6 ) to the back compartments (5 and 10). This differential may decrease as the baghouse seasons with continued operation.
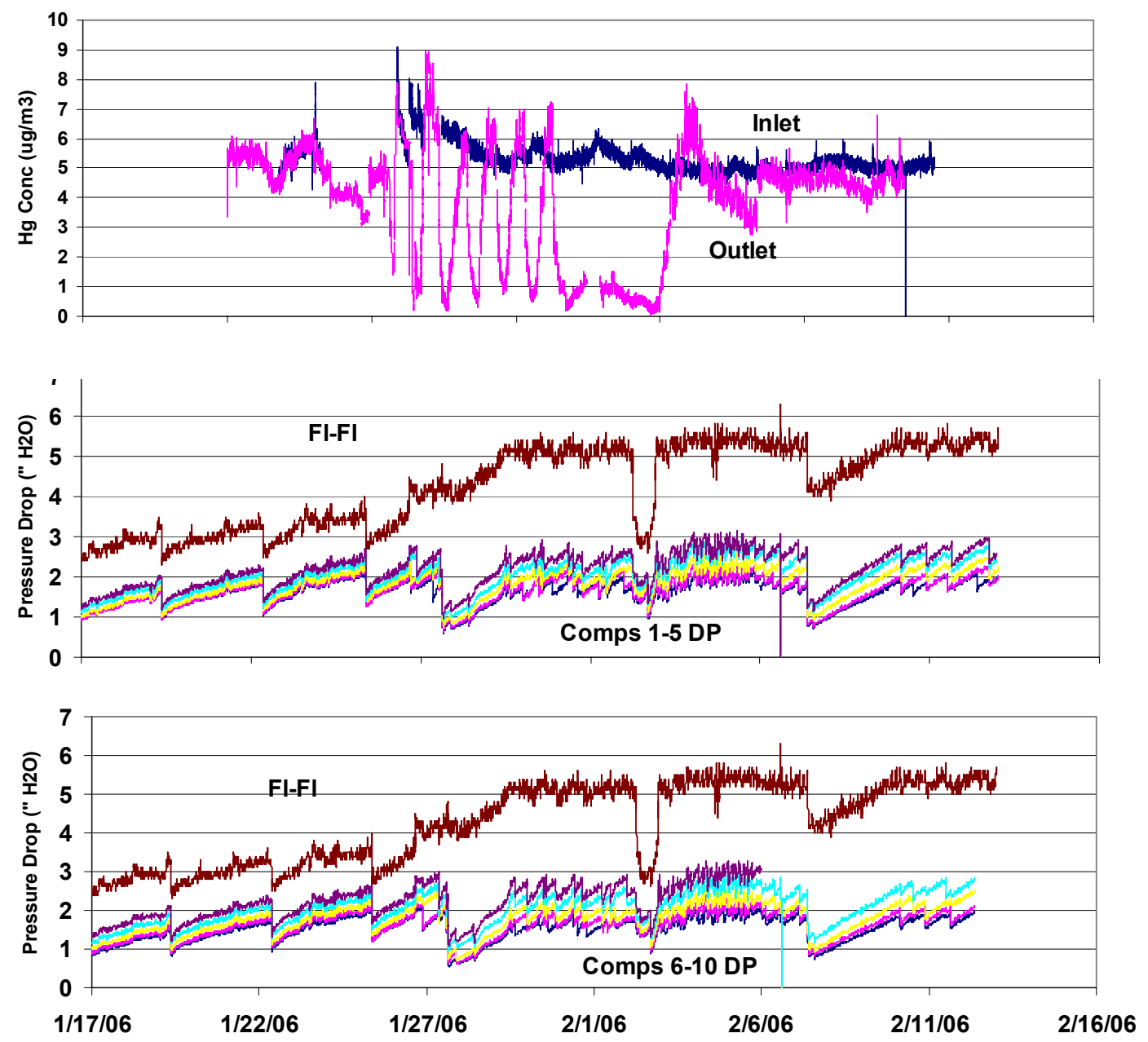

Figure 2. Inlet and outlet mercury concentrations and baghouse pressure drop, January 17 - February 12, 2006. 


\section{Baseline Tests (February 13 - February 16)}

Baseline tests were performed during the week of February 13. Baseline testing was done without PAC injection. Efforts during this week included sampling of coal and ash, monitoring the CEMs and plant data, and performing mercury, halogen, and particulate testing on the flue gas into and out of the baghouse.

\section{Flue Gas Testing}

GE Energy was contracted by ADA-ES to measure flue gas constituents at the inlet and outlet of the baghouse. On February 14, 15 and 16 they conducted manual measurements per the test plan, which included:

- Ontario Hydro measurements for mercury at the common inlet and outlet duct;

- Sorbent trap (Method 324) measurements for mercury at the outlet of the air heater in each individual duct and the common outlet duct;

- Method 5 for particulate loading at the common inlet and outlet ducts; and

- Method 26A for halogens at the common outlet duct.

The report from GE Energy is attached as Appendix A.

\section{Flue Gas Temperature Measurements}

During baseline testing GE Energy performed various flue gas measurements. As part of the traverse process for the Ontario Hydro Method, flue gas temperatures were taken at 24 points at both the inlet and outlet duct to the baghouse (Figure 3 ).

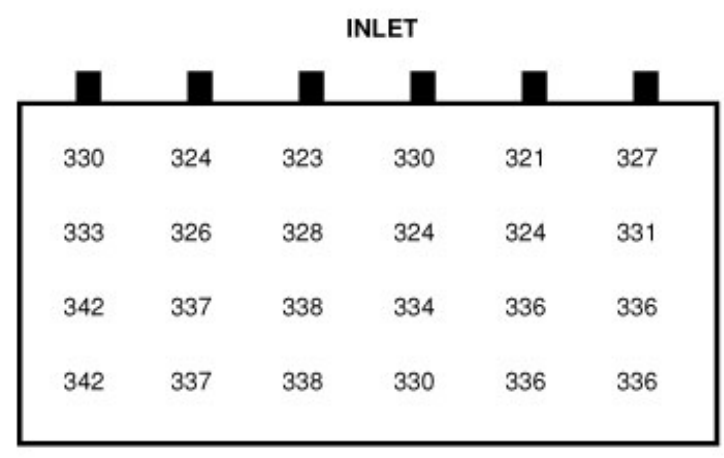

\section{OUTLET}

\begin{tabular}{llll|}
332 & 333 & 333 & 333 \\
333 & 333 & 333 & 333 \\
332 & 332 & 333 & 332 \\
331 & 330 & 332 & 332 \\
330 & 330 & 330 & 330 \\
330 & 331 & 331 & 331 \\
\hline
\end{tabular}

Figure 3. Baghouse Temperature Profile. 
The results and comparison with the plant temperature data from the EDS are shown in Table 2. The overall comparison between the plant data and the GE data shows very little difference between maximum and minimum, especially considering that the GE data was taken in 5 minute intervals and not simultaneously.

Table 2. Flue Gas Temperature Comparison

\begin{tabular}{|l|l|l|l|l|}
\hline $\begin{array}{l}\text { GE Energy Temperature DATA Profile in Ducts from 9:25 a.m. to } \\
\text { 12:00 noon on 2-14-06 }\end{array}$ \\
\hline & Inlet Min. & $\begin{array}{l}\text { Inlet } \\
\text { Max. }\end{array}$ & $\begin{array}{l}\text { Outlet } \\
\text { Min. }\end{array}$ & $\begin{array}{l}\text { Outlet } \\
\text { Max. }\end{array}$ \\
\hline GE Energy & 324 & 342 & 330 & 333 \\
\hline EDS & 332 & 339 & 326 & 334 \\
\hline
\end{tabular}

\section{Particulate Measurements}

A total of 24 test points were sampled using six ports at the baghouse common inlet and outlet test locations. The particulate sample trains met all specifications required by Method 5, 40CFR60. The filter media were Whatman 934-AH glass microfibre filters exhibiting a $>99.97 \%$ efficiency on 0.3 micron particles. Triplicate sampling was performed at the inlet and outlet. Table 3 shows the results of this study. The average removal across the baghouse was $99.6 \%$, with an emission rate of $0.00011 \mathrm{lb} / \mathrm{MMBtu}$.

Table 3. Particulate Removal across the Baghouse

\begin{tabular}{|l|l|l|l|}
\hline Run \# & Inlet (lb/hr) & Outlet (lb/hr) & Removal (\%) \\
\hline 1 & 84.868 & $4.179^{*}$ & \\
\hline 2 & 104.438 & 0.368 & \\
\hline 3 & 141.192 & 0.556 & \\
\hline Average & 110.166 & 0.462 & $\mathbf{9 9 . 6 \%}$ \\
\hline
\end{tabular}

*Not included in average due to inconsistency

\section{Hydrogen Halide and Halogen Measurements}

Hydrogen chloride $(\mathrm{HCl})$, hydrogen bromide $(\mathrm{HBr})$, bromine $\left(\mathrm{Br}_{2}\right)$ and chlorine $\left(\mathrm{Cl}_{2}\right)$ concentrations were determined using Method 26A, 40CFR60. Three integrated twenty-fourpoint samples were extracted from the common outlet gas stream. The inlet was not measured. Table 4 lists the results of these measurements.

Table 4. Hydrogen Halide and Halogen Measurements

\begin{tabular}{|l|l|l|l|l|}
\hline Run \# & HCl (ppm) & HBr (ppm) & $\mathbf{C l}_{\mathbf{2}} \mathbf{( p p m )}$ & $\mathbf{B r}_{\mathbf{2}}$ (ppm) \\
\hline 1 & 3.79 & $0.16^{*}$ & 0.00 & 0.00 \\
\hline 2 & 3.90 & 0.00 & 0.00 & 0.00 \\
\hline 3 & 3.73 & 0.00 & 0.00 & 0.00 \\
\hline Average & 3.81 & 0.00 & 0.00 & 0.00 \\
\hline
\end{tabular}

* Not included in average due to inconsistency 


\section{Mercury Measurements}

A total of 24 test points were sampled using six ports at the baghouse common inlet and outlet test locations. The speciated mercury sample trains met all specifications required by the Ontario Hydro method. Triplicate tests were performed at the inlet and outlet. Figure 4 shows how the Ontario Hydro measurements compare with the Thermo CEM.

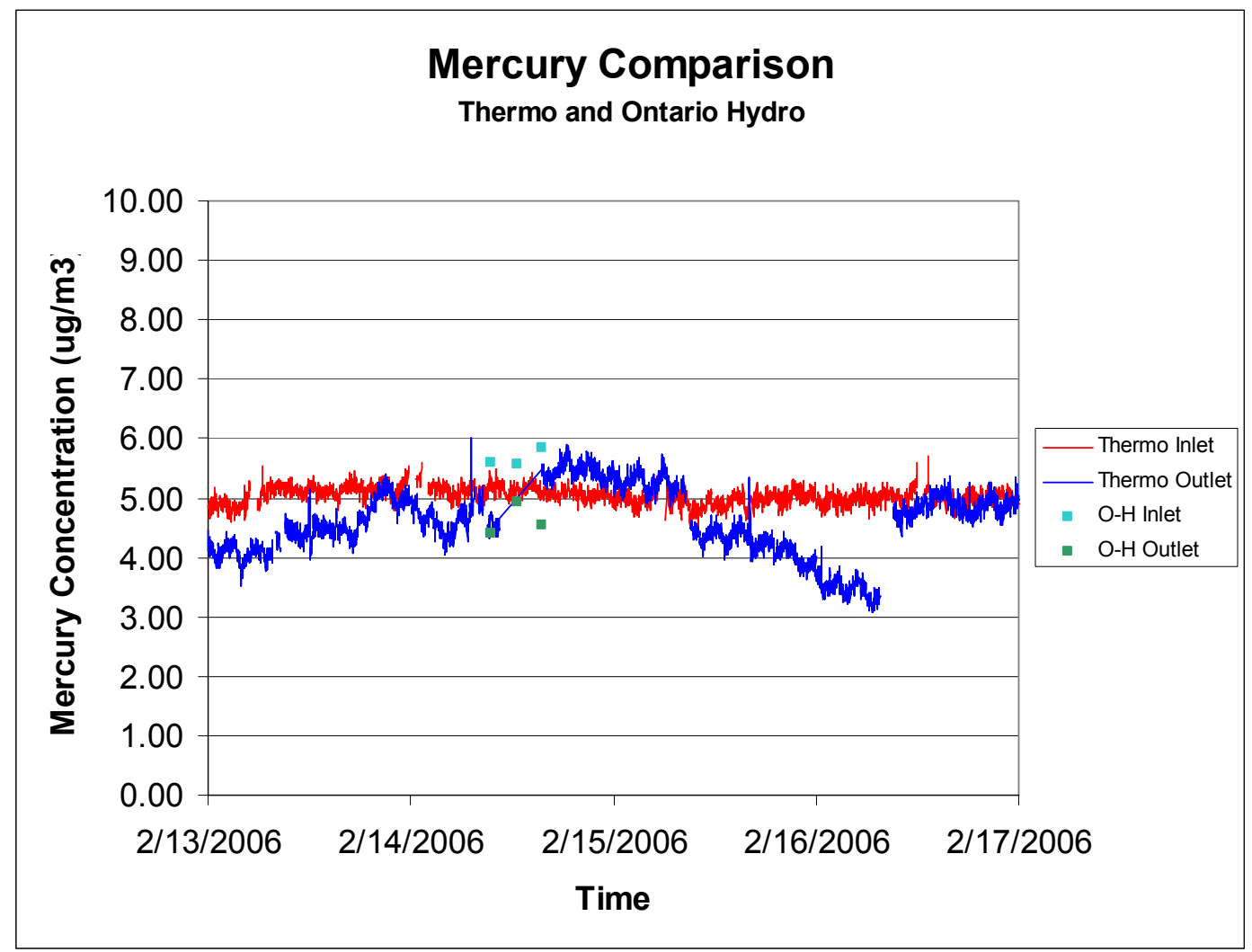

Figure 4. Thermo CEM and Ontario Hydro Measurements

Table 5 shows the average inlet and outlet measurements from 10 am through 4 pm using the Thermo CEM and comparing with the Ontario Hydro Method. There was a $0.6 \%$ difference between inlet and outlet based on the CEM, but $9 \%$ when using the Ontario Hydro Method. The CEM and the Ontario Hydro results differed by $12 \%$ and $4.6 \%$, which is well within the $20 \%$ agreement required by EPA to pass the Relative Accuracy Test Audit (RATA) for mercury.

Table 5. Comparison of Thermo CEM and Ontario Hydro Data

\begin{tabular}{|l|l|l|l|}
\hline Test Method & $\begin{array}{l}\text { Inlet Average } \\
\left(\boldsymbol{\mu g} / \mathbf{s m}^{\mathbf{3}}\right)\end{array}$ & $\begin{array}{l}\text { Outlet Average } \\
\left(\boldsymbol{\mu g} / \mathbf{s m}^{\mathbf{3}}\right)\end{array}$ & $\begin{array}{l}\text { Differential } \\
(\mathbf{\%})\end{array}$ \\
\hline Thermo CEM & 4.99 & 4.96 & $\mathbf{0 . 6 \%}$ \\
\hline Ontario Hydro & 5.67 & 5.20 & $\mathbf{9 . 0 \%}$ \\
\hline Differential (CEM \& O-H) & $\mathbf{1 2 \%}$ & $\mathbf{4 . 6 \%}$ & \\
\hline
\end{tabular}


Based on the Ontario Hydro data, the elemental mercury at the inlet was $91 \%$ of the total and oxidized was the balance, with just a trace of the mercury particle-bound. At the outlet, the elemental portion was $88 \%$, with the remainder in the oxidized form.

Vapor phase mercury emissions were also measured in accordance with the USEPA Draft Method 324. A single point was used for paired train sorbent sampling at the outlet of the air preheaters of units 7, 8, and 9, and the common baghouse outlet. Sorbent traps included main and backup sections in series. The sorbent trap was supported on a probe and inserted directly into the flue gas stream. Sampling was performed at a constant rate of approximate $0.4 \mathrm{l} / \mathrm{min}$ for a period of two hours. Table 6 gives the results of these tests. There was considerable variation between the triplicate tests as well as between inlet and outlet. GE Energy stated that they were having difficulty with the connections with the sorbent traps during the tests. Some traps were very difficult to separate and others separated unintentionally during assembly, and in one case sampling. This lack of consistency brings into question the usefulness of these results.

\section{Table 6. Method 324 Results}

\begin{tabular}{|c|c|c|c|c|}
\hline $\begin{array}{l}\text { Sample } \\
\text { Location }\end{array}$ & $\begin{array}{l}\text { Run \#1 Conc. } \\
\left(\mu \mathrm{g} / \mathrm{sm}^{3}\right)\end{array}$ & $\begin{array}{l}\text { Run \#2 Conc. } \\
\left(\mu \mathrm{g} / \mathrm{sm}^{3}\right)\end{array}$ & $\begin{array}{l}\text { Run \#3 Conc. } \\
\left(\mu \mathrm{g} / \mathrm{sm}^{3}\right)\end{array}$ & $\begin{array}{l}\text { Average Conc. } \\
\left(\mu \mathrm{g} / \mathrm{sm}^{3}\right)\end{array}$ \\
\hline Unit 7 & 0.86 & 0.66 & 0.62 & 0.71 \\
\hline Unit 8 & 0.65 & 0.54 & 4.45 & 1.88 \\
\hline Unit 9 & 15.66 & 40.85 & 15.59 & 24.04 \\
\hline Outlet & 2.55 & 4.66 & 4.89 & 4.04 \\
\hline
\end{tabular}

\section{Performance Data}

Data was downloaded from the Thermo CEMs and the EDS for the week of baseline testing. Figure 5 shows inlet and outlet mercury concentrations, flange-to-flange pressure drop and inlet temperature. There was some drift on the outlet CEM because the calibration routine was not programmed properly. When this was corrected and the instrument began undergoing daily calibrations, the mercury levels returned to the expected values. 

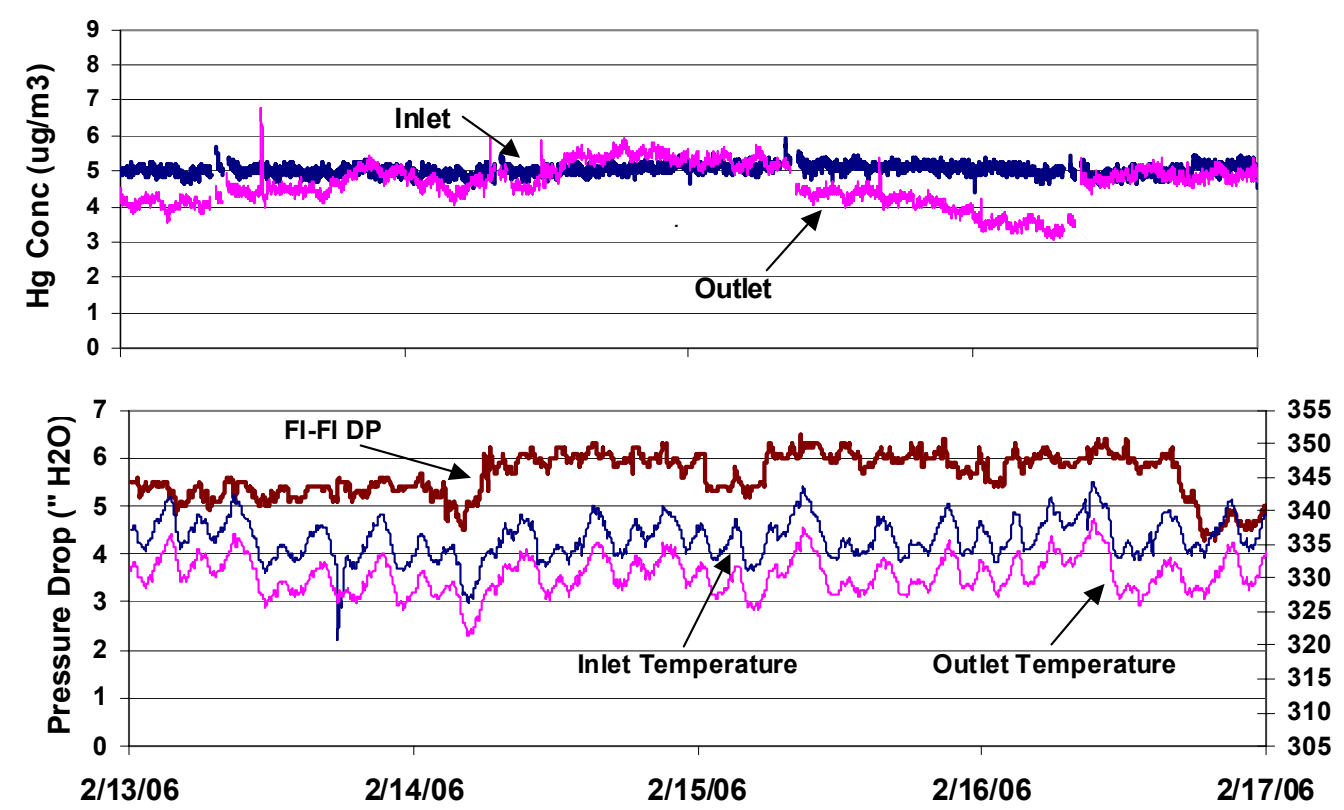

Figure 5. Inlet and outlet mercury concentrations and baghouse pressure and temperature, February 13 - February 17, 2006.

\section{Sample Collection and Analysis}

During baseline testing, coal and ash samples were collected from the coal feeders on Units 7-9, the hot-side ESP ash hoppers and the TOXECON ${ }^{\mathrm{TM}}$ baghouse hoppers. The goal for this sampling campaign was to collect sufficient samples to determine:

1. Variations in coal mercury concentration between the three units and between the four feeders on each unit;

2. Mercury concentration in the ash collected in the hot-side ESPs; and

3. Mercury concentration in and variation between hoppers of the ash collected by the TOXECON ${ }^{\mathrm{TM}}$ baghouse.

The following table lists the samples collected:

Table 7. Coal and Ash Sampling Schedule - Baseline

\begin{tabular}{|l|l|l|l|}
\hline Sample & Location & Dates & \# Samples \\
\hline Coal & $\begin{array}{l}\text { Feeders A1, A2, B1, B2 } \\
\text { on Units 7-9 }\end{array}$ & $\begin{array}{l}2 / 14-2 / 16 / 06 \\
(12 \text { samples per day) }\end{array}$ & 36 total \\
\hline ESP Ash & Unit 7 hoppers (A-L) & $2 / 14 / 06$ & 12 \\
\hline ESP Ash & Unit 8 hoppers (A-L) & $2 / 15 / 06$ & 12 \\
\hline ESP Ash & Unit 9 hoppers (A-L) & $2 / 16 / 06$ & 12 \\
\hline Baghouse Ash & Hoppers 1-10 & $\begin{array}{l}2 / 14-2 / 16 / 06 \\
(10 \text { samples per day) }\end{array}$ & 30 total \\
\hline
\end{tabular}


Samples were shipped to ADA-ES, where portions of the samples were analyzed. Depending on the analysis, samples were analyzed either by ADA-ES or sent to outside laboratories for the appropriate testing. Not all samples taken were analyzed, but all of them are stored for future analyses, if needed. Table 8 lists the analyses scheduled for the samples.

Table 8. Coal and Ash Analysis Schedule - Baseline

\begin{tabular}{|l|l|}
\hline Sample & Analysis \\
\hline Coal & Ultimate, Proximate, $\mathrm{Hg}, \mathrm{Cl}$ \\
\hline ESP Ash & Loss on Ignition (LOI) and $\mathrm{Hg}$ \\
\hline Baghouse Ash & LOI and $\mathrm{Hg}$ \\
\hline
\end{tabular}

Table 9 shows some of the results from the baseline tests on the coal and ash. Details of the individual test results received to date are shown in Appendix B. The following table does not list the results from the ultimate and proximate tests due to space constraints.

Table 9. Coal and Ash Results - Baseline

\begin{tabular}{|l|l|}
\hline Sample and Test & Results \\
\hline Coal $\mathrm{Hg}$ & $35-89 \mathrm{ng} / \mathrm{g}$ \\
\hline Coal Cl & $43-116 \mu \mathrm{g} / \mathrm{g}$ \\
\hline ESP Ash Hg & $<10 \mathrm{ng} / \mathrm{g}$ \\
\hline ESP Ash LOI & $0.61-1.5 \%$ \\
\hline Baghouse Ash Hg & $1790-14100 \mathrm{ng} / \mathrm{g}$ \\
\hline Baghouse Ash LOI & $6-18 \%($ after PAC startup testing) \\
\hline
\end{tabular}

Typical LOI values for the ESP ash were below 1\%. The results from the baghouse ash were higher since there was residual PAC from the startup operations. The mercury level in the baghouse ash was also much higher due to the residual PAC from startup. There was no apparent pattern between coal feeders based on the mercury and chlorine results.

\section{Baghouse Cleaning Cycle}

Baghouse cleaning was set to initiate a clean@6.5” W.C. or every 72 hours. Each clean consisted of pulsing 6 of the 36 pulse pipes in each compartment until the pressure drop decreased by 0.5 " W.C., when cleaning was stopped. On the next cleaning cycle, the pulsing picked up where it left off. During any cleaning cycle all of the pipes in every compartment may or may not be pulsed.

\section{Parametric Testing (February 20 - March 1)}

Parametric testing was scheduled to begin February 20, 2006. The overall goal of these tests was to establish a correlation between injection of DARCO Hg and mercury removal. Secondary goals included understanding the variables that impact mercury removal performance and to document any changes in baghouse performance. Table 10 summarizes the proposed test conditions. 
To minimize variables, it was decided to operate the baghouse at a pressure drop of nominally 6" W.C. and use a cleaning logic that was similar to baseline testing. It was also agreed that a parametric test would be considered complete when the mercury removal reached a level $\pm 5 \%$ for 24 hours.

Table 10. Parametric Test Conditions with DARCO Hg

\begin{tabular}{|c|c|c|}
\hline $\begin{array}{c}\text { Inj. Conc. } \\
\text { (lbs/MMacf) }\end{array}$ & $\begin{array}{c}\text { Feedrate } \\
\text { (lbs/h) }\end{array}$ & Comments \\
\hline 0.5 & 30 & Establish baseline with PAC \\
\hline 3.0 & 180 & Build up DP (at this rate for $\sim 8 \mathrm{~h}$ ) \\
\hline 0.5 & 30 & \\
\hline 1.0 & 60 & \\
\hline 1.5 & 90 & \\
\hline 2.0 & 120 & Evaluate high temp operation \\
\hline 2.5 & 150 & Evaluate cleaning sequence equalize comp DP's \\
\hline 3.0 & 180 & \\
\hline 2.0 & 120 & \\
\hline TBD & TBD & \\
\hline
\end{tabular}

Prior to parametric testing, the baghouse was put through one complete cleaning cycle to remove residual dust cake that was formed when the units were being brought on line. This was done by initiating a manual clean cycle six times to ensure every pipe in every compartment was pulsed. The flange-flange (fl-fl) pressure drop decreased to nominally 4.5 inches W.C.. To increase the fl-fl pressure to the target of 6.0 inches W.C., PAC injection was started on February 17 at $0.5 \mathrm{lbs} / \mathrm{MMacf}$ but there were problems with the ash unloader so PAC injection was discontinued over the weekend. On Monday February 20, the injection was resumed at a relatively high rate of $3 \mathrm{lbs} / \mathrm{MMacf}$ and then lowered as pressure drop increased. The effect of these injection rates can be seen in Figure 6. 

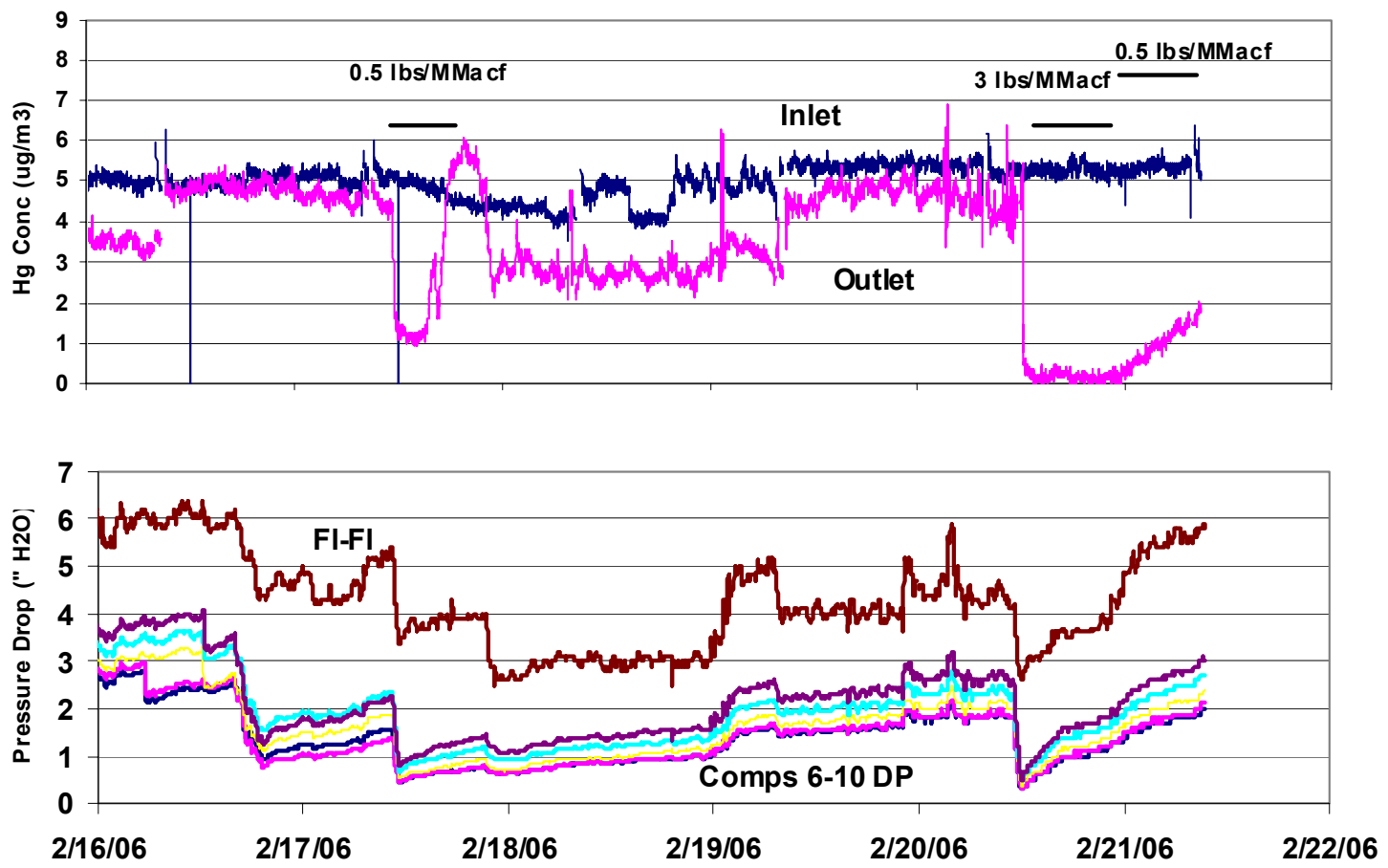

Figure 6. Inlet and outlet mercury concentrations and baghouse pressure drop, February 16 - February 21, 2006.

A log of parametric and operational changes can be found in Table 11.

Table 11. Operation Log During Parametric Tests

\begin{tabular}{|c|c|c|l|}
\hline Date & Time & $\begin{array}{c}\text { PAC Inj } \\
\text { (lb/MMacf) }\end{array}$ & Operation Log \\
\hline \hline $2 / 16 / 06$ & $16: 00$ & 0 & Initiate 6 clean cycles (1 full clean) \\
\hline $2 / 17 / 06$ & $11: 15$ & 0.5 & Cleaning completed, start PAC injection \\
\hline $2 / 17 / 06$ & $15: 23$ & 0 & Ash unloader broken, no PAC injection until fixed \\
\hline $2 / 19 / 06$ & $23: 08$ & 0 & One mill on Unit 9 offline \\
\hline $2 / 20 / 06$ & $7: 50$ & 3 & Increase carbon injection rate to build DP \\
\hline $2 / 20 / 06$ & $16: 35$ & 0.5 & Lower injection rate to begin parametric tests \\
\hline $2 / 21 / 06$ & $00: 12$ & 0.5 & Mill on Unit 9 came back on line \\
\hline $2 / 23 / 06$ & $5: 30$ & 0.8 & Control glitch caused increase in PAC rate \\
\hline $2 / 23 / 06$ & $8: 00$ & 1.0 & Increase to second parametric test condition \\
\hline $2 / 24 / 06$ & $21: 20$ & 0.45 & Control glitch caused decrease in PAC rate \\
\hline $2 / 25 / 06$ & $4: 18$ & 0.5 & Control glitch caused increase in PAC rate \\
\hline $2 / 25 / 06$ & $6: 45$ & 1.5 & Increase to third parametric test condition \\
\hline $2 / 27 / 06$ & $8: 30$ & 2.0 & Increase to fourth parametric test condition \\
\hline
\end{tabular}




\section{Performance Data}

On February 20 PAC injection was set at $0.5 \mathrm{lbs} /$ MMacf. By February 22, outlet mercury concentration leveled out. This gradual increase in outlet mercury was caused by the residual carbon on the bags from operation at $3 \mathrm{lbs} /$ MMacf. As the carbon capacity was used up, the mercury removal rate decreased until a quasi-equilibrium was reached on February 22. At this condition, outlet mercury cycled between about 2.5 and $4.8 \mu \mathrm{g} / \mathrm{m}^{3}$; these changes can be seen in Figure 7. After considering several variables that could affect outlet mercury concentration, including temperature, flow, pressure drop, pulse cleaning, carbon feed and hopper ash pulling, it became apparent that outlet mercury concentration was mainly varying with inlet flue gas temperature.
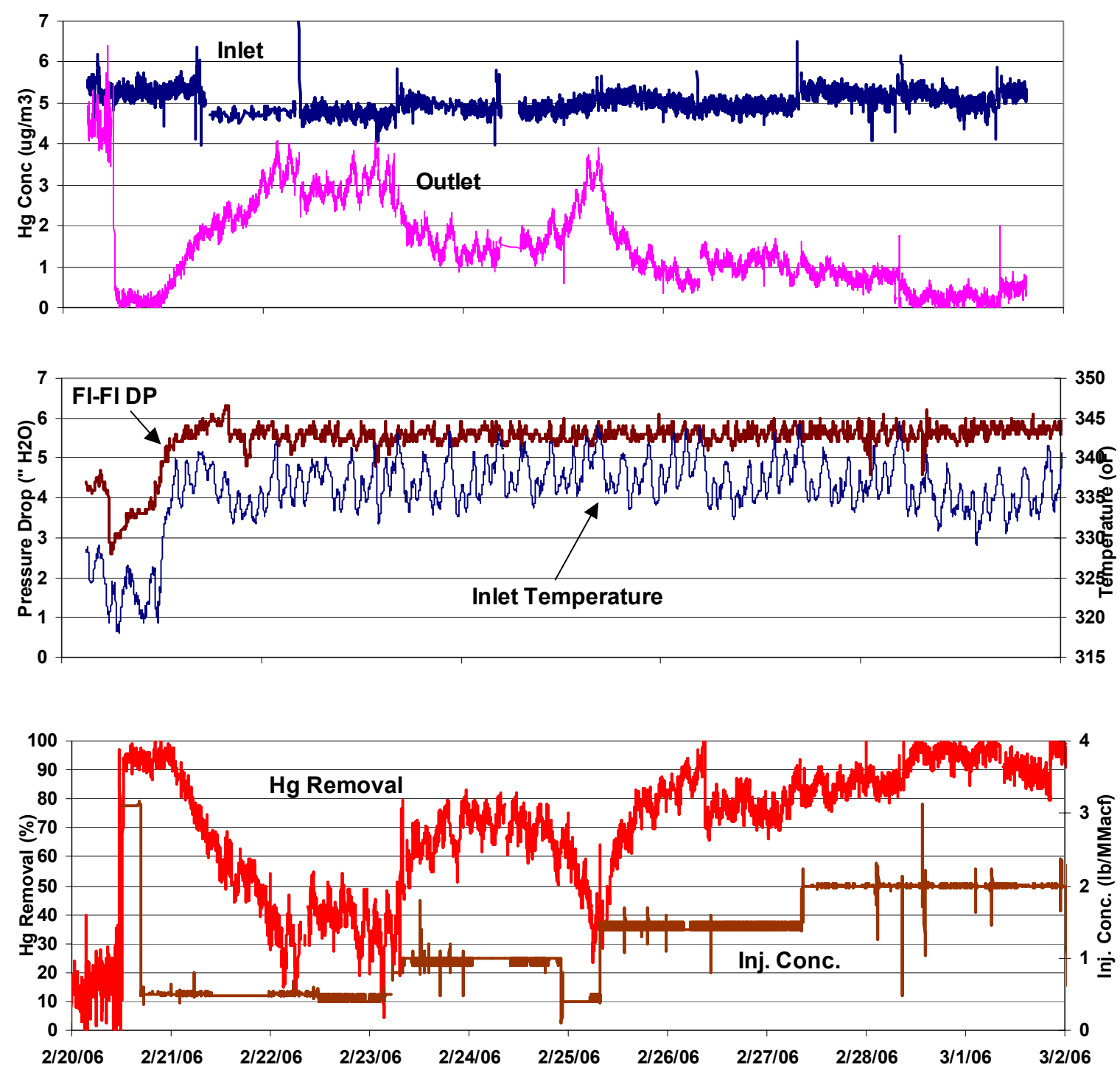

Figure 7. Inlet and outlet mercury concentrations, carbon injection concentration, baghouse pressure drop, inlet temperature and removal February 20 - March 1, 2006. 
Because of the significant and unexpected, but consistent variation in outlet mercury with temperature, the criteria of operating for 24 hours at a removal efficiency (RE) $\pm 5 \%$ was waived.

On February 23 the injection concentration was increased to $1.0 \mathrm{lb} / \mathrm{MMacf}$. Average RE was nominally $73 \%$, but varied between 69 and $80 \%$. When injection concentration was increased, a slight increase in fl-fl pressure drop was also seen.

On February 25 the injection concentration was increased to $1.5 \mathrm{lb} / \mathrm{MMacf}$. Average RE was nominally $80 \%$, but varied between 70 and $85 \%$.

On February 27 the injection concentration was increased to $2.0 \mathrm{lb} / \mathrm{MMacf}$. The average RE was nominally $90 \%$, but varied between 80 and $95 \%$.

The relationship between mercury removal and inlet temperature during testing at 1 lb/MMacf can be seen in Figure 8. The cycling pattern of inlet temperature and the similar pattern for outlet mercury concentration are illustrated in Figure 9.

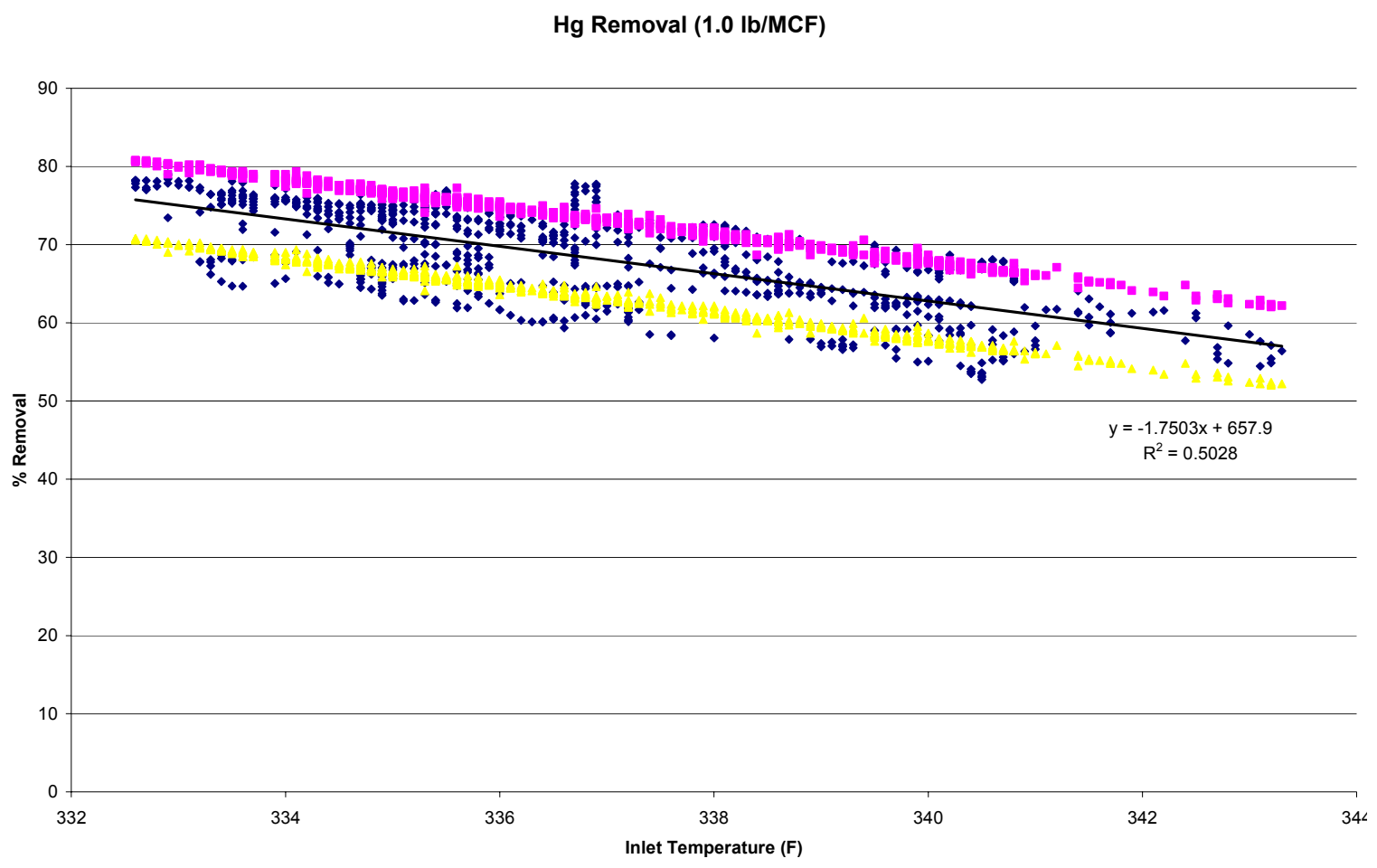

Figure 8. Linear regression showing relationship between inlet temperature and mercury removal efficiency and $+/-5 \%$ band. 


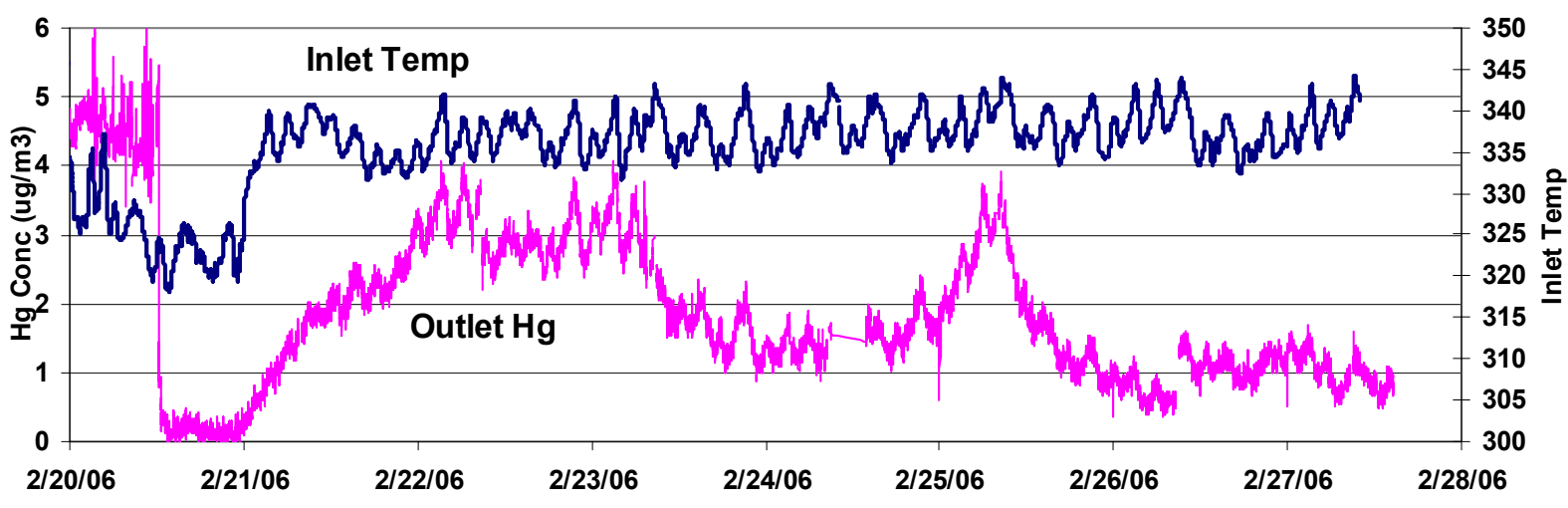

Figure 9. Inlet Temperature and Outlet Mercury Concentration.

The obvious and instantaneous response in outlet mercury concentration to changes in inlet temperature is surprising, especially in the magnitude of the change: a $10^{\circ} \mathrm{F}$ increase in temperature appears to result in up to a $1 \mu \mathrm{g} / \mathrm{m}^{3}$ increase in mercury. We do know that this temperature range, $333-350^{\circ} \mathrm{F}$, is where DARCO $\mathrm{Hg}$ begins to lose its ability to adsorb mercury so it is possible that we are just seeing the sensitivity in performance as temperature increases. Another factor is that as temperatures increase, mercury desorbs from the sorbent (activated carbon or ash) until a new equilibrium is reached. We believe we saw this during the shake down period when outlet mercury was higher than inlet mercury after carbon injection was stopped.

The overall removal efficiencies from the parametric tests can be seen in Table 12.

Table 12. Results from Parametric Tests with DARCO Hg

\begin{tabular}{|c|c|c|c|c|}
\hline $\begin{array}{c}\text { Inj. Conc. } \\
\text { (lbs/MMacf) }\end{array}$ & $\begin{array}{c}\text { Feedrate } \\
\text { (lbs/h) }\end{array}$ & $\begin{array}{c}\text { Results } \\
\text { (\% removal) }\end{array}$ & $\mathbf{\pm \% \text { Range }}$ & Comments \\
\hline 0.5 & 30 & $\sim 38$ & & \\
\hline 3.0 & 180 & $\sim 96$ & & RE varies with temp \\
\hline 0.5 & 30 & $\sim 38$ & $20-50$ & RE varies with temp \\
\hline 1.0 & 60 & $\sim 73$ & $69-80$ & RE varies with temp \\
\hline 1.5 & 90 & $\sim 80$ & $70-85$ & RE varies with temp \\
\hline 2.0 & 120 & $\sim 90$ & $80-95$ & \\
\hline
\end{tabular}

\section{Sample Collection and Analysis}

During parametric testing, coal and ash samples were collected from the coal feeders on Units 7-9, the hot-side ESP ash hoppers and the TOXECON ${ }^{\mathrm{TM}}$ baghouse hoppers. Table 13 lists the sampling schedule. These samples were shipped to ADA-ES and stored. They will be analyzed as needed to determine: 
1. Variation in coal mercury concentration between the three units and between the four feeders on each unit;

2. Mercury concentration in the ash collected in the hot-side ESPs; and

3. Mercury concentration in and variation between hoppers of the ash collected by the TOXECON ${ }^{\mathrm{TM}}$ baghouse.

Table 13. Coal and Ash Sampling Schedule - Parametric

\begin{tabular}{|l|l|l|l|}
\hline \multicolumn{1}{|c|}{ Sample } & Location & Dates & \# Samples \\
\hline Coal & Feeder A1 on Units 7-9 & $\begin{array}{l}\text { M, W, F } \\
(3 \text { samples per day })\end{array}$ & 9 total/week \\
\hline ESP Ash & Hopper A on Units 7-9 & $\begin{array}{l}\text { M, W, F } \\
(3 \text { samples per day })\end{array}$ & 9 total/week \\
\hline Baghouse Ash & Hoppers 1-10 & $\begin{array}{l}\text { M, W, F } \\
(10 \text { samples per day })\end{array}$ & 30 total/week \\
\hline
\end{tabular}

\section{Overheating of PAC/Ash in Baghouse Hoppers}

Hot, burning embers were found in the compartment \#5 hopper of the TOXECONTM baghouse on March 1. The compartment \#5 hopper was plugging during ash removal on February 28 and an inspection was performed to determine the cause. This compartment was isolated and the baghouse remained in service. All of the compartments were then checked and embers were found in all of the hoppers. The compartments were isolated on March 2 and the baghouse put into bypass mode. This section documents the events that occurred and testing that has been conducted to date to determine the cause of this unexpected event.

The following is a detailed timeline of the events:

\section{Timeline}

- Parametric testing: PAC injection rate increased to $2.0 \mathrm{lb} / \mathrm{MMacf}$ on Sunday, 2/26.

- On Tuesday, 2/28, a report indicated that plugging of the hopper throat was occurring on compartment \#5. On Monday, 2/27 some embers were found during ash sampling. It was not clear what was causing the plugging or embers.

- On Wednesday, 3/1, hot embers were again found in the hopper of compartment \#5. This compartment was isolated and the baghouse remained in service. An investigation began to determine the cause of the problem. Reports from all other TOXECON ${ }^{\mathrm{TM}}$ projects were that this had never happened before.

- On Thursday, 3/2, hot embers were found in all the baghouse hoppers. PAC injection was stopped at approximately 2:00 am when this was noticed. The baghouse was put in bypass mode and the compartments isolated. The hoppers were first flooded with water, allowed to cool, and then the ash vacuumed out.

- On Friday, 3/3, all of the hoppers had been cleaned and the ash handling system cleaned. The baghouse was returned from bypass mode to in service mode. All compartments were in service. Pressure drops and opacity levels looked normal. However, we had 
previously been cautioned that bag problems would not be expected to be evident by these readings.

- There was some indication that at least one ash hopper was not completely emptying. Rat-holing was noticed when the inspection door was opened.

- Samples of the activated carbon from the PAC silo were taken for testing and analysis. Samples were sent to Norit and ADA-ES. Samples from the ash hoppers were also taken to be analyzed as needed.

- The only known source of external heat appears to be the hopper heaters, which were normally on and maintain hopper wall temperatures between $230^{\circ} \mathrm{F}$ and $275^{\circ} \mathrm{F}$ as measured by a device mounted external to the hopper.

- Some flanges on the hoppers were found to be loose. Any leakage in this area would cause air to enter the hoppers.

- No overheating problems were found in either the PAC silo or the ash silo.

- On 3/7, compartment \#4 was opened and inspected. Ash was seen in areas on the tube sheet. Bags were pulled from these areas and many showed melted bag material, especially near the bottom of the bag. The inspection was complete on $3 / 10$. There were 117 failed bags in Compartment 4A and none in Compartment 4B. All compartment inspection sheets are in Appendix C.

- On 3/13 Compartment \#3 was opened and inspected. There were 83 failed bags in 3A and none in $3 \mathrm{~B}$.

- On 3/16 Compartments \#5 and \#7 were opened and inspected. There were no failed bags seen. Three bags were taken for testing from each compartment.

- On 3/17 Compartments \#1 and \#6 were opened and inspected. There were no failed bags seen. Three bags were taken for testing from each compartment.

- On 3/20 Compartments \#9 and \#10 were opened and inspected. There were no failed bags seen. Three bags were taken for testing.

- On 3/21 Compartments \#2 and \#8 were opened and inspected. There were no failed bags seen. Three bags were taken for testing from each compartment. One P84 test bag and one BHA membrane test bag was taken from compartment \#8.

- On 3/24 using scaffolding placed inside the hoppers of Compartments \#3, \#4, and \#9, a detailed inspection of the bottom of the bags and interior of the hoppers was performed. All of the bags were checked by physically examining the bottom portion of each bag to determine if they were stiff or had lost flexibility due to overheating. No problems were found. In addition, samples of deposits on the hopper walls were taken for lab analysis.

\section{PAC and Ash Analysis}

The PAC sample from the silo sent to ADA-ES was split and a portion sent to a local analytical laboratory for a thermo gravimetric analysis. This analysis determines the temperature of combustion in air. The PAC began losing significant weight at about $400^{\circ} \mathrm{C}$ $\left(750^{\circ} \mathrm{F}\right)$. The PAC had a temperature of ignition at $456^{\circ} \mathrm{C}\left(852^{\circ} \mathrm{F}\right)$, which is consistent with the MSDS for this type of carbon. The TGA report is in Appendix D.

PAC/ash samples from Compartment \#4 baghouse hoppers on 2/24 and 2/27 were also sent for TGA tests. The sample from $2 / 24$ lost approximately $5 \%$ of the total weight by $314^{\circ} \mathrm{C}$, indicating some relatively volatile material was coming off at these lower temperatures. The 
pure PAC from the silo did not show this trend. The sample from $2 / 27$ did not show that initial weight loss as might be expected, but when this sample was taken, it was the first time that embers were seen in the hopper, so the sample had already been heated to a high temperature, which would have driven off any volatiles.

We Energies also performed a TGA on the PAC using nitrogen gas. They found that the pure PAC from the silo lost significant weight at about $475^{\circ} \mathrm{C}$, which is similar to the test performed by ADA-ES (Figure 10). The TGA tests were then repeated using air as a purge gas. At $500^{\circ} \mathrm{F}$ and $550^{\circ} \mathrm{F}$, there was no weight loss and no visual sign of embers. Initial sample weight loss began at $720^{\circ} \mathrm{F}$ and the profile was similar to the test run by ADA-ES.

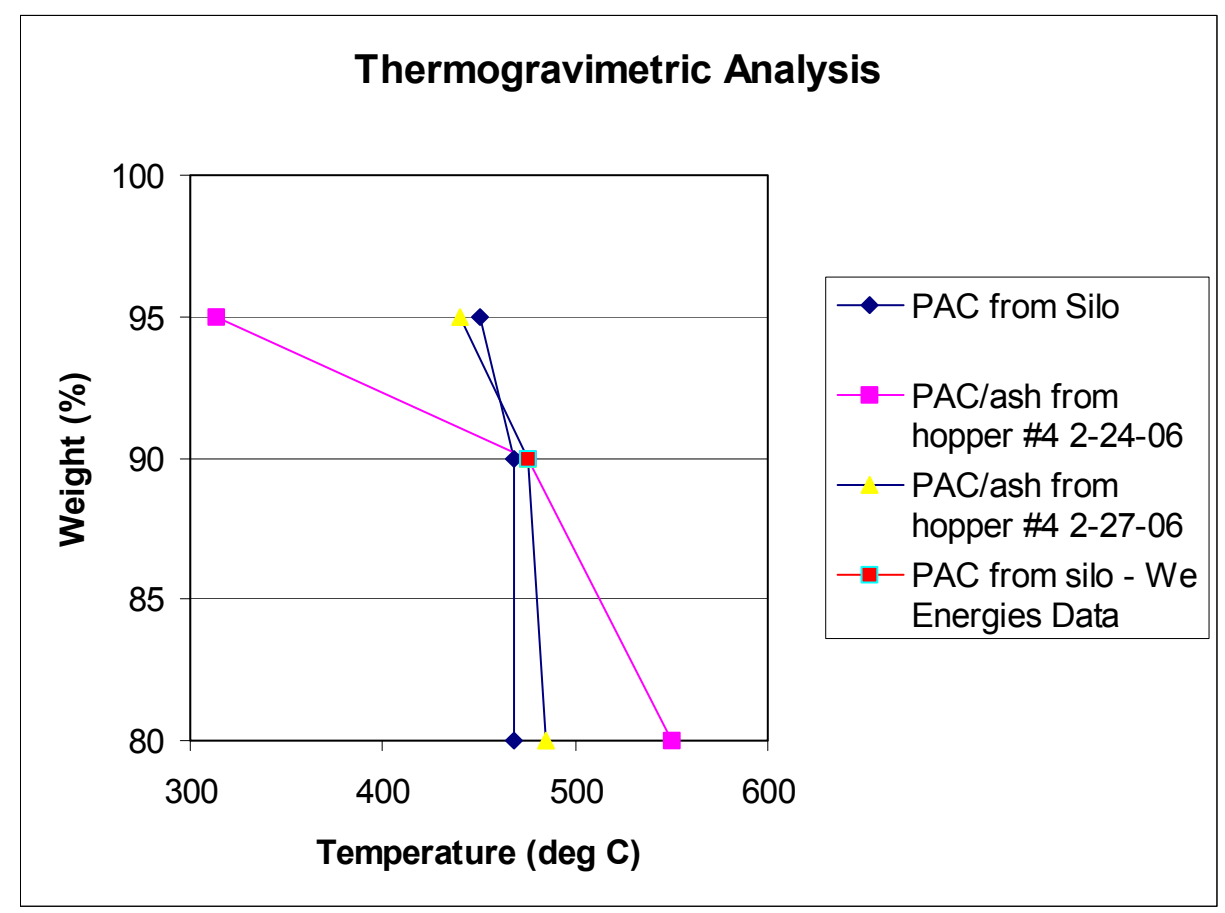

Figure 10. Combustion Temperature Comparison of PAC and PAC/ash

We Energies also performed a series of tests using an open cup flash point determination apparatus. This apparatus consists of a heavy cup on a hot plate with an open flame above to ignite any volatiles released as the material in the cup is heated. There was no release of combustible volatile compounds at temperatures up to $500^{\circ} \mathrm{F}$. However, when removing the sample material from the cup after allowing several hours for cooling, they noted glowing embers in the bottom of the cup along with a significant amount of gray/ash material indicating that combustion had occurred at the bottom of the cup. The material on the surface of the cup had shown no evidence of combustion occurring. This shows that PAC can ignite on contact with a hot surface under low oxygen conditions and maintain combustion.

We Energies performed another series of tests in the flash point apparatus. PAC/Ash mixtures were placed in the cup, and thermocouples were positioned at the bottom of the cup 
and approximately $1 / 4$ " from the bottom. There seemed to be no significant difference in the temperature at which smoldering was first observed, indicating that the presence of ash does not change the temperature of ignition of PAC. Table 14 shows the results of these tests.

Table 14. Temperature Comparisons on PAC and PAC/ash Mixtures

\begin{tabular}{|c|c|c|c|}
\hline Sample & $\begin{array}{c}\text { Bottom } \\
\text { Temperature } \\
\left({ }^{0} \mathbf{F}\right)\end{array}$ & $\begin{array}{c}\text { Bulk Sample } \\
\text { Temperature }\left({ }^{\circ} \mathbf{F}\right)\end{array}$ & Observations \\
\hline \multirow[t]{4}{*}{ PAC } & 650 & 395 & No change in appearance \\
\hline & 700 & 490 & No change in appearance \\
\hline & 750 & 560 & No change in appearance \\
\hline & 784 & 580 & Smoldering occurred \\
\hline \multirow[t]{4}{*}{ PAC/ash 4:1 } & 650 & 375 & No change in appearance \\
\hline & 700 & 445 & No change in appearance \\
\hline & 750 & 520 & No change in appearance \\
\hline & 779 & 570 & Smoldering occurred \\
\hline \multirow[t]{4}{*}{ PAC/ash 2:1 } & 650 & 430 & No change in appearance \\
\hline & 700 & 445 & No change in appearance \\
\hline & 750 & 480 & No change in appearance \\
\hline & 792 & 560 & Smoldering occurred \\
\hline \multirow[t]{4}{*}{ PAC/ash 1:1 } & 650 & 430 & No change in appearance \\
\hline & 700 & 440 & No change in appearance \\
\hline & 750 & 490 & No change in appearance \\
\hline & 799 & 535 & Smoldering occurred \\
\hline
\end{tabular}

ADA-ES performed two long-term tests on PAC and PAC/ash from the baghouse hoppers. On March 3, a $50 \mathrm{~g}$ sample of PAC from the silo was placed in an open crucible and then in an oven set at $320^{\circ} \mathrm{F}$. The sample was stirred every few days to check for changes below the surface, but it showed no change in appearance or sparklers after 10 days in the oven. In addition, on March 3, a sample of PAC and a sample of the PAC/ash from the hoppers was placed on a piece of rusty carbon steel and placed in the oven to see if there was any interaction with the metal. There was no change in appearance after 10 days of heating at $320^{\circ} \mathrm{F}$.

\section{Column Reactor Tests}

ADA-ES designed and built a column reactor for testing PAC and PAC/ash to measure any increase in temperature from heat of adsorption. The reactor was 2" diameter stainless steel construction with multiple ports for thermocouples. Figure 11 is a picture of the apparatus. 
In this reactor, PAC or PAC/ash would be loaded into the column and gas introduced into the bottom of the column. Multiple thermocouples placed in the center of the bed monitored temperature. Heat tape provided the heat source for the column. The gas entering the column could be heated as needed also.

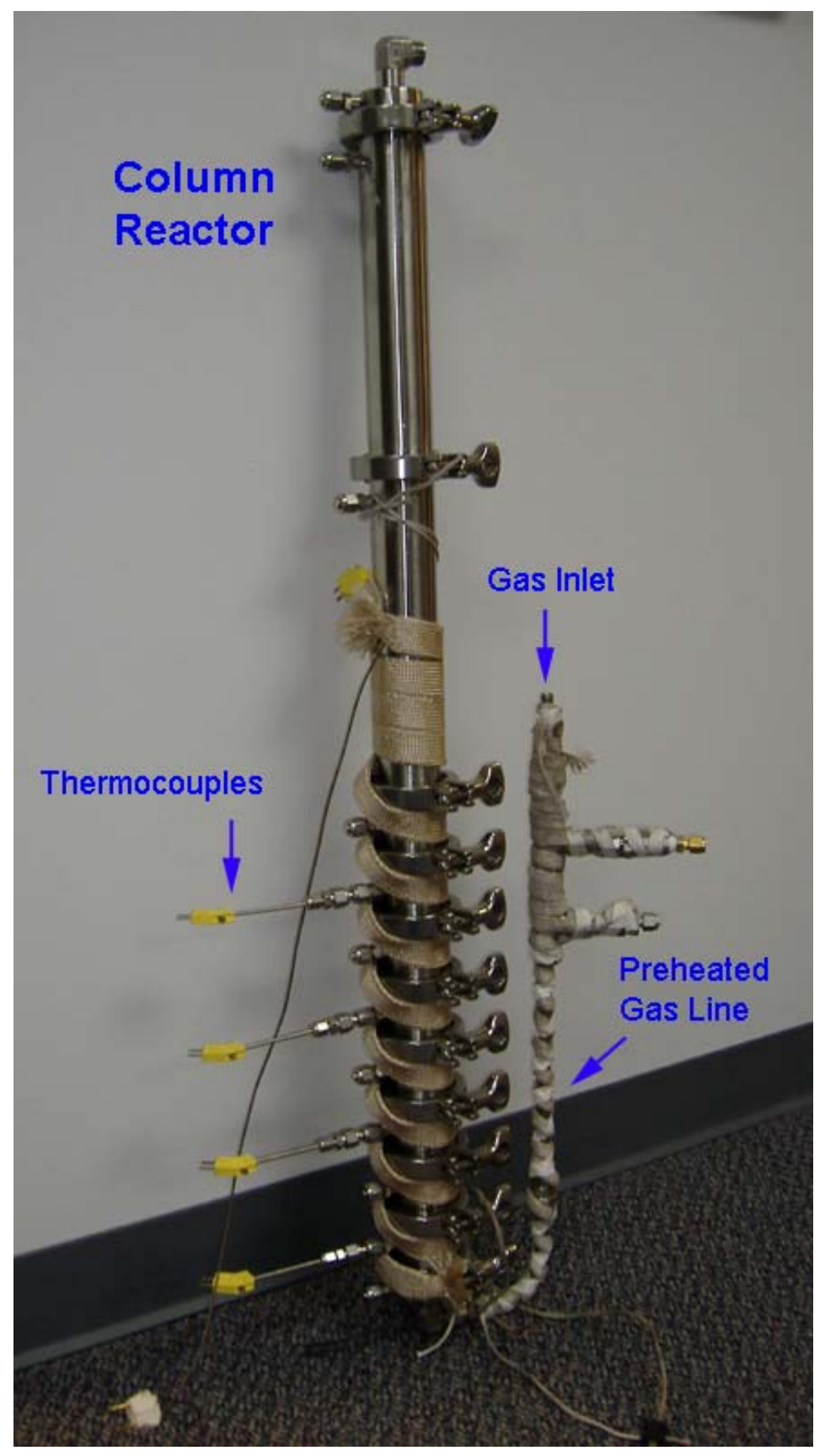

Figure 11. Column Reactor

Details of the tests performed using this apparatus in March are listed in Table 15. 
Table 15. Column Reactor Tests

\begin{tabular}{|l|l|l|l|l|l|l|}
\hline Test \# & $\begin{array}{c}\text { Column } \\
\text { Material }\end{array}$ & $\begin{array}{c}\text { Inlet Gas/Bed } \\
\text { Temperature } \\
(\mathbf{F})\end{array}$ & $\begin{array}{c}\text { Gas } \\
\text { Composition }\end{array}$ & $\begin{array}{l}\text { Gas Flow } \\
\text { Rate } \\
(\mathbf{c c} / \text { min) }\end{array}$ & $\begin{array}{l}\text { Gas Contact } \\
\text { Time (hr) }\end{array}$ & $\begin{array}{c}\text { Time with } \\
\text { No Gas Flow } \\
\text { (hr) }\end{array}$ \\
\hline 1 & PAC & 70 & Air & 500 & 4 & 4 \\
\hline 2 & PAC & 70 & $\begin{array}{l}\text { Simulated } \\
\text { Flue Gas }\end{array}$ & 500 & 4 & 4 \\
\hline 3 & PAC & 340 & $\begin{array}{l}\text { Simulated } \\
\text { Flue Gas }\end{array}$ & 500 & 4 & 4 \\
\hline
\end{tabular}

The simulated flue gas used in the column tests contained similar major gases at close to the amounts found in the flue gas at Presque Isle. Table 16 lists the gases used.

\section{Table 16. Simulated Flue Gas Composition}

\begin{tabular}{|l|c|}
\hline Flue Gas Component & Amount \\
\hline $\mathrm{CO} 2$ & $13.5 \%$ \\
\hline $\mathrm{O} 2$ & $5.5 \%$ \\
\hline Moisture & $11 \%$ \\
\hline $\mathrm{SO} 2$ & $225 \mathrm{ppm}$ \\
\hline
\end{tabular}

The first test at ambient conditions is shown in Figure 12 and only air showed a minimal temperature rise that corresponded to the ambient temperature increase. This shows that air contact and/or adsorption has no appreciable effect on PAC temperature.

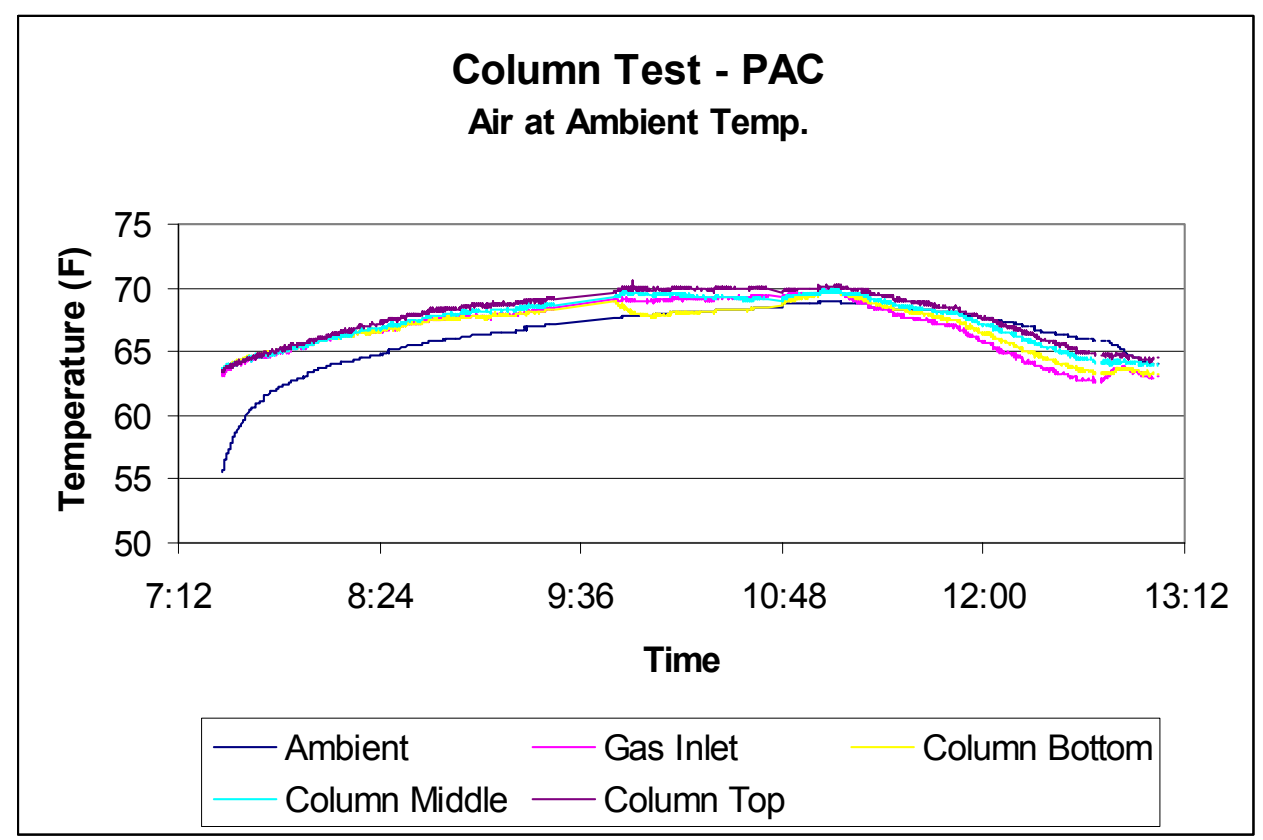

Figure 12. Column Test - PAC with Air at Ambient Temperature. 
The second test using air at a temperature similar to the flue gas temperature going into the baghouse showed similar results (Figure 13).

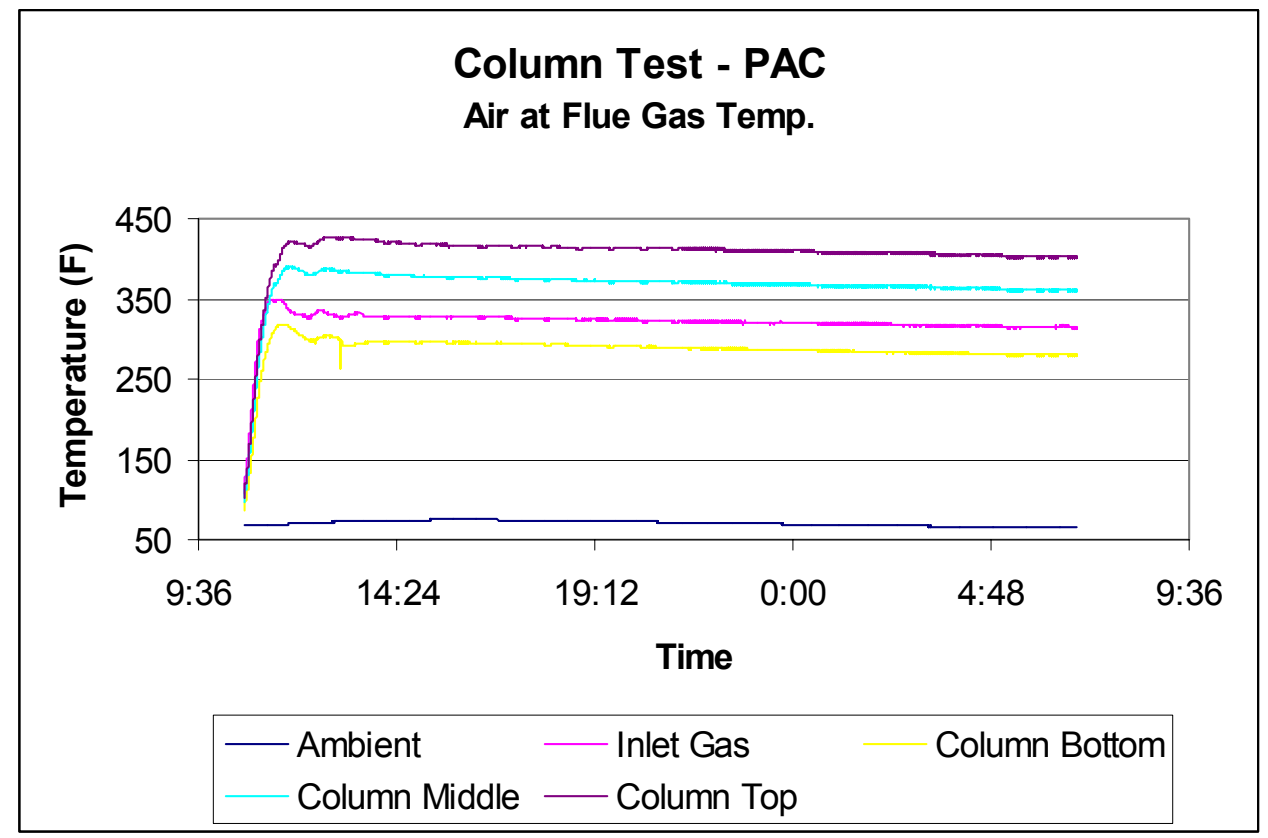

\section{Figure 13. Column Test - PAC with Air at Flue Gas Temperature.}

Figure 14 shows the results using the simulated flue gas. When the gas flow was terminated, the gas inlet value went down and the temperature in the middle thermocouple went up. Since the other two column thermocouples did not respond, this may have been an anomaly. In general, the PAC did not exhibit any heat of adsorption using the simulated flue gas.

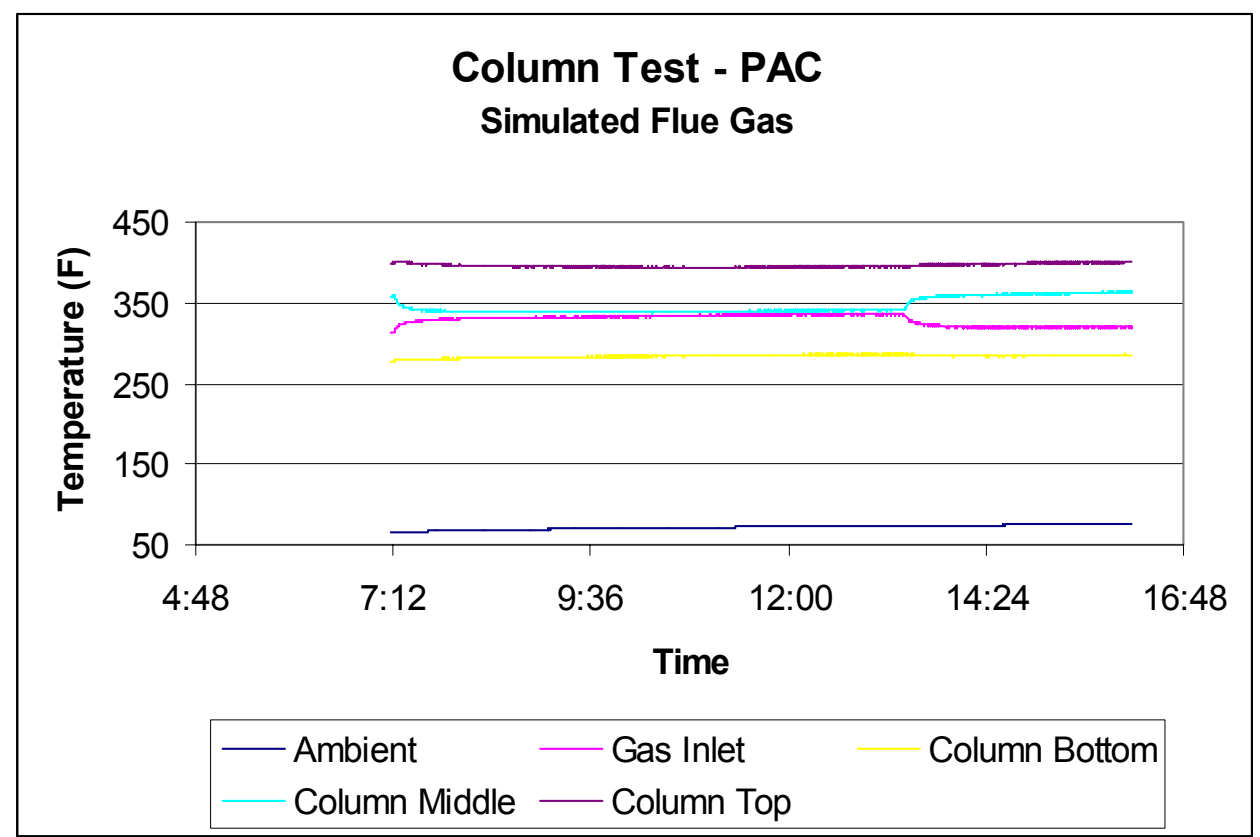

Figure 14. Column Test - PAC with Simulated Flue Gas 


\section{Flue Gas Temperature Comparison}

A comparison was made of the inlet and outlet baghouse temperatures to determine if there was any indication of overheating. Figure 15 shows inlet and outlet temperatures along with flange-to-flange pressure drop across the baghouse. There did not seem to be any indication of problems with heating or pressure before or during the overheating event.

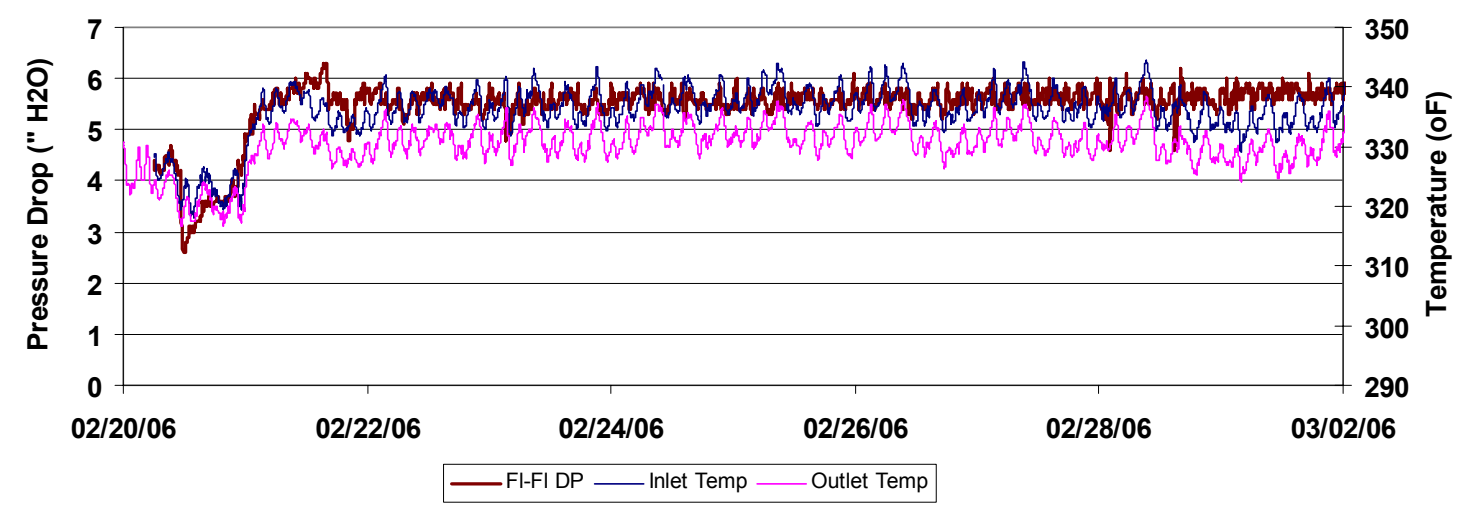

Figure 15. Baghouse Temperature Comparison

\section{TOXECONTM Comparison}

Overheating of the PAC/ash mixture has not been seen at any plant using PAC injection or the TOXECON ${ }^{\mathrm{TM}}$ process. A year-long TOXECON ${ }^{\mathrm{TM}}$ test was performed at Plant Gaston with no incident of overheating in the hoppers. Table 17 lists various parameters from each plant. 
Table 17. Comparison of Presque Isle and Plant Gaston

\begin{tabular}{|c|c|c|}
\hline & Gaston & PIPP \\
\hline Manufacturer & Hamon Research Cottrell & Wheelabrator Air Pollution Control \\
\hline Type & Low Pressure Pulse-jet & Medium Pressure Pulse-jet \\
\hline Configuration & Hot-side ESP/COHPAC & Hot-side ESP/TOXECON \\
\hline Coal & Low sulfur eastern bituminous & PRB \\
\hline Design air-to-cloth (gross) & 8.5 & 5.5 \\
\hline Cleaning & On-line & On-line \\
\hline Max cleaning $(\mathrm{p} / \mathrm{b} / \mathrm{h})$ & 4.4 (1.75 Тур.) & \\
\hline Bag length (feet) & 23 & 26 \\
\hline Bag diameter (inches) & 4.9 equivalent (oval bag) & 5.0 \\
\hline Bag material (Nominal Wgt.) & 18 ounce/yd $\mathrm{d}^{2}$ PPS & 18 ounce/yd $\mathrm{d}^{2}$ PPS \\
\hline Pulse pressure (psi) & 12 & 60 \\
\hline Ash loading (gr/acf) & $0.03-0.14$ & 0.0048 \\
\hline Outlet emissions (lbs/MMacf) & 0.0045 & 0.034 \\
\hline Ash LOI (\%) & $11-25$ & $<0.5$ \\
\hline PAC Type & Norit DARCO Hg & Norit DARCO Hg \\
\hline PAC loading (lbs/MMacf) & $0.5-2.0$ & $0.5-2.0$ \\
\hline PAC loading (gr/acf) & $0.0016-0.0128$ & $0.0032-0.0128$ \\
\hline Time of operation with PAC & 8 months & $\sim 5$ weeks \\
\hline Hopper heaters & None & $\begin{array}{l}\text { Yes, Thermon resistance heaters } \\
(12.5 \mathrm{~kW} / \text { hopper })\end{array}$ \\
\hline Hopper evacuation schedule & $\begin{array}{l}\text { Every 2-3 hours per B. Corina at } \\
\text { Gaston. (when requested, operators } \\
\text { would shut off ash pulling system } \\
\text { to build up ash for a sample) }\end{array}$ & Every 12 hours \\
\hline Fluidizing System & Vibrators & Vibrators \\
\hline Ash system & Wet, hydroveyor system & Dry, pneumatic \\
\hline Overheating of hopper ash/PAC & No & Yes, all hoppers \\
\hline No. Cage Sections & 2 & 2 \\
\hline
\end{tabular}

\section{Baghouse Cage Inspections}

During the inspections for damaged bags due to overheating, personnel noticed that several of the cages were separated at the connecting collar. A more detailed inspection of the cages in one compartment was initiated. This inspection showed that a majority of the cages had some kind of defect (installation or fabrication) that had to be fixed. A decision was made to inspect and repair, as needed, every cage in every compartment. This process was anticipated to take about three weeks and will be completed in the next reporting period. 
During the inspection of Compartment \#1 the crew noticed that the pulse pipe $j$-tubes on the exterior wall in section 1B had $1 / 4-1 / 2$ " of precipitate near the openings. The precipitate was very hard, brittle, and smelled of sulfur (Figures 16 and 17). Samples were taken and bagged. The majority of the precipitate was at the horizontal run where the tube connected with the pulse pipe. There were also small piles of this precipitate below the connection of the pulse pipes and the j-tubes where this had leaked out from the tube. There was no precipitate buildup in the pulse pipes themselves although there were signs that precipitate-laden liquid had run down some of the cages in the first row near the wall. The j-tubes in section $1 \mathrm{~A}$ had no noticeable precipitate (Figure 18). The precipitate was cleaned out before the pulse pipes were reinstalled. It is anticipated that this problem will be fixed by adding insulation around the j-tubes where they are external to the baghouse structure. This should be completed during the next reporting period.

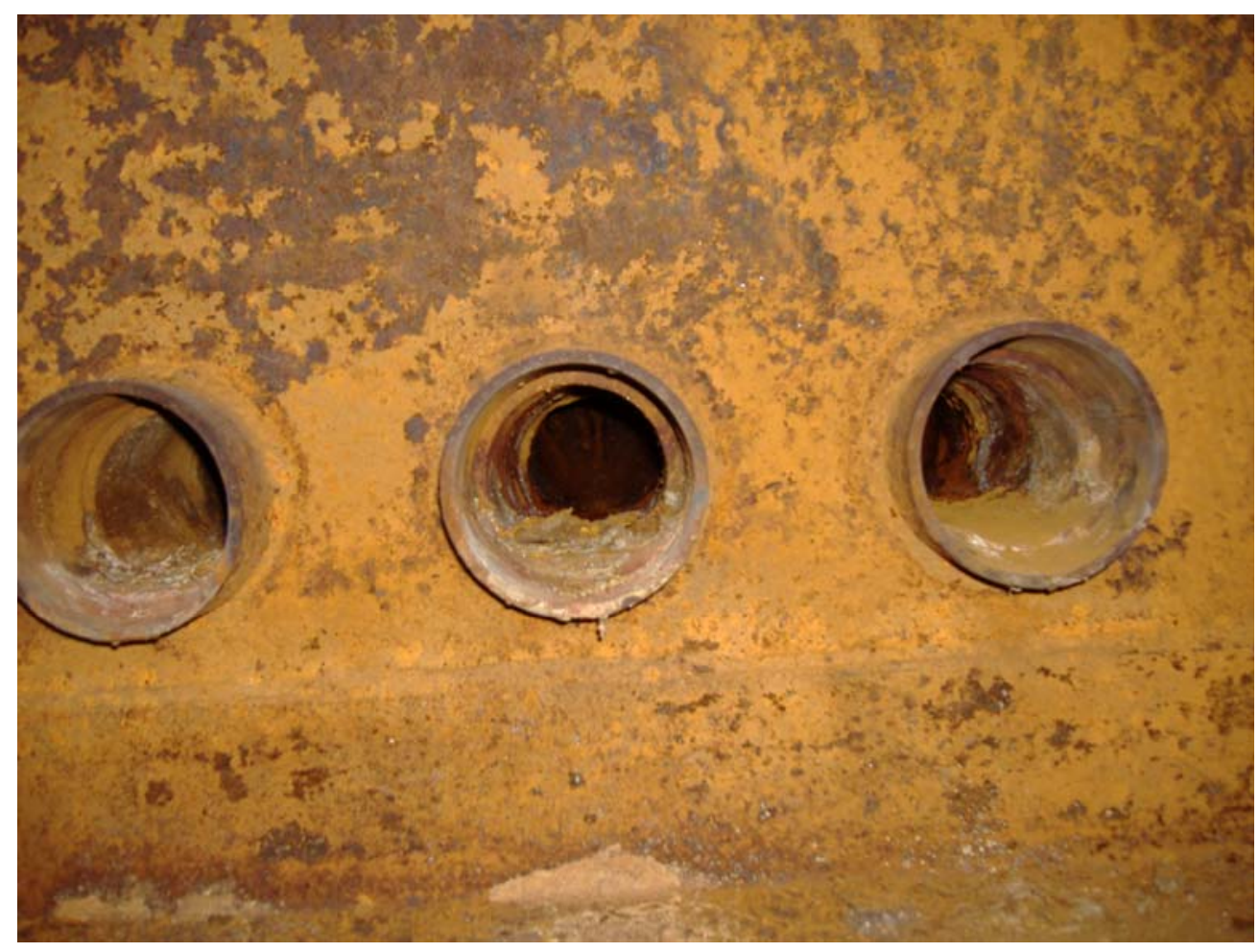

Figure 16. Precipitate in Compartment \#1 


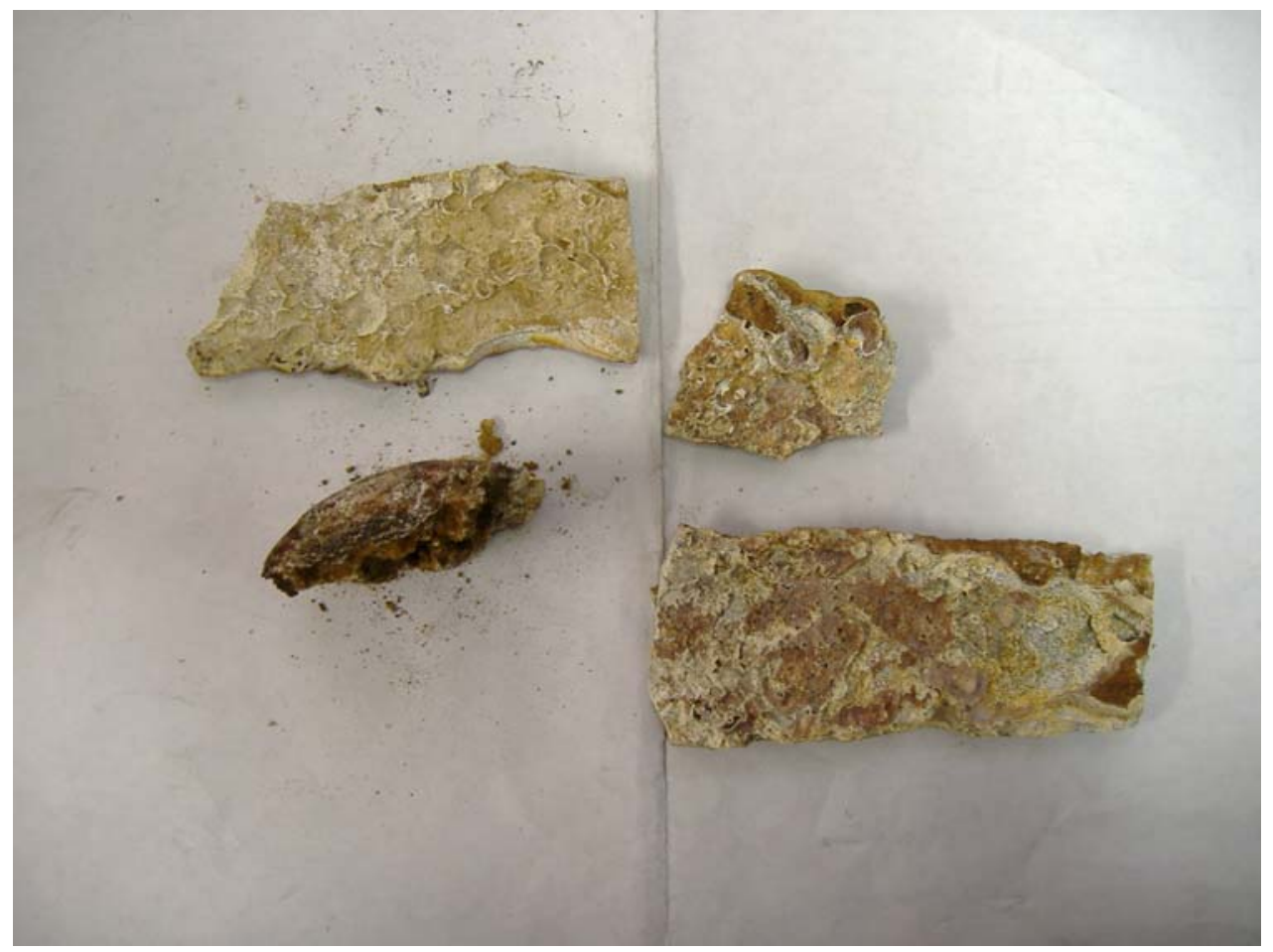

Figure 17. Close-up of Precipitate from Compartment \#1

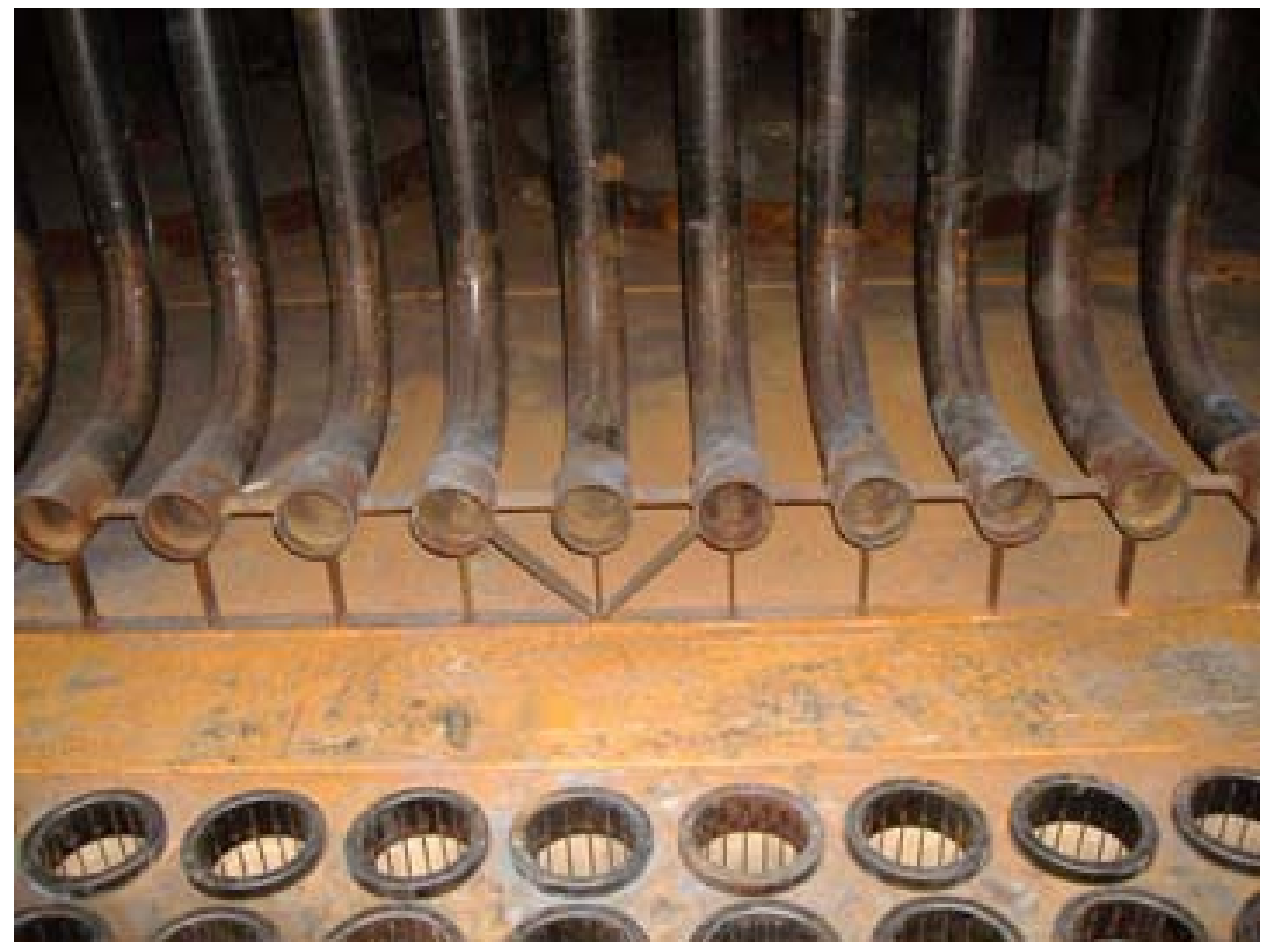

Figure 18. Interior Wall j-tubes in Compartment \#1 


\section{Hopper Test}

On March 30, We Energies performed a test in Compartment \#4 hopper. Four thermocouples were welded to each interior hopper wall. These were placed so that they would be 6" below the upper surface of PAC. One thermocouple was also placed between the hottest heater and the outside wall of the hopper. Four thermocouples were wired to metal rods, which were then placed in the PAC bed (Figures 19 and 20). The ends of the thermocouples were located $2.5^{\prime}$ above the bottom of the rod.

A total of $360 \mathrm{lbs}$ of PAC was then loaded into the hopper. This was approximately 4' of material. The hopper heaters were turned on at 12:46 pm. The temperature in the hopper reached approximately $395^{\circ} \mathrm{F}$ with the rate of increase becoming negligible (Figure 21), so the test was terminated at $3: 52 \mathrm{pm}$. The plan was to start the heaters again when there is flue gas going into the hopper. The maximum temperature reached in the PAC bed was $173^{\circ} \mathrm{F}$ (Figure 22). The hopper heater control was set to $275^{\circ} \mathrm{F}$ but the highest indication it gave was $210^{\circ} \mathrm{F}$ and the heater never cycled off during the test.

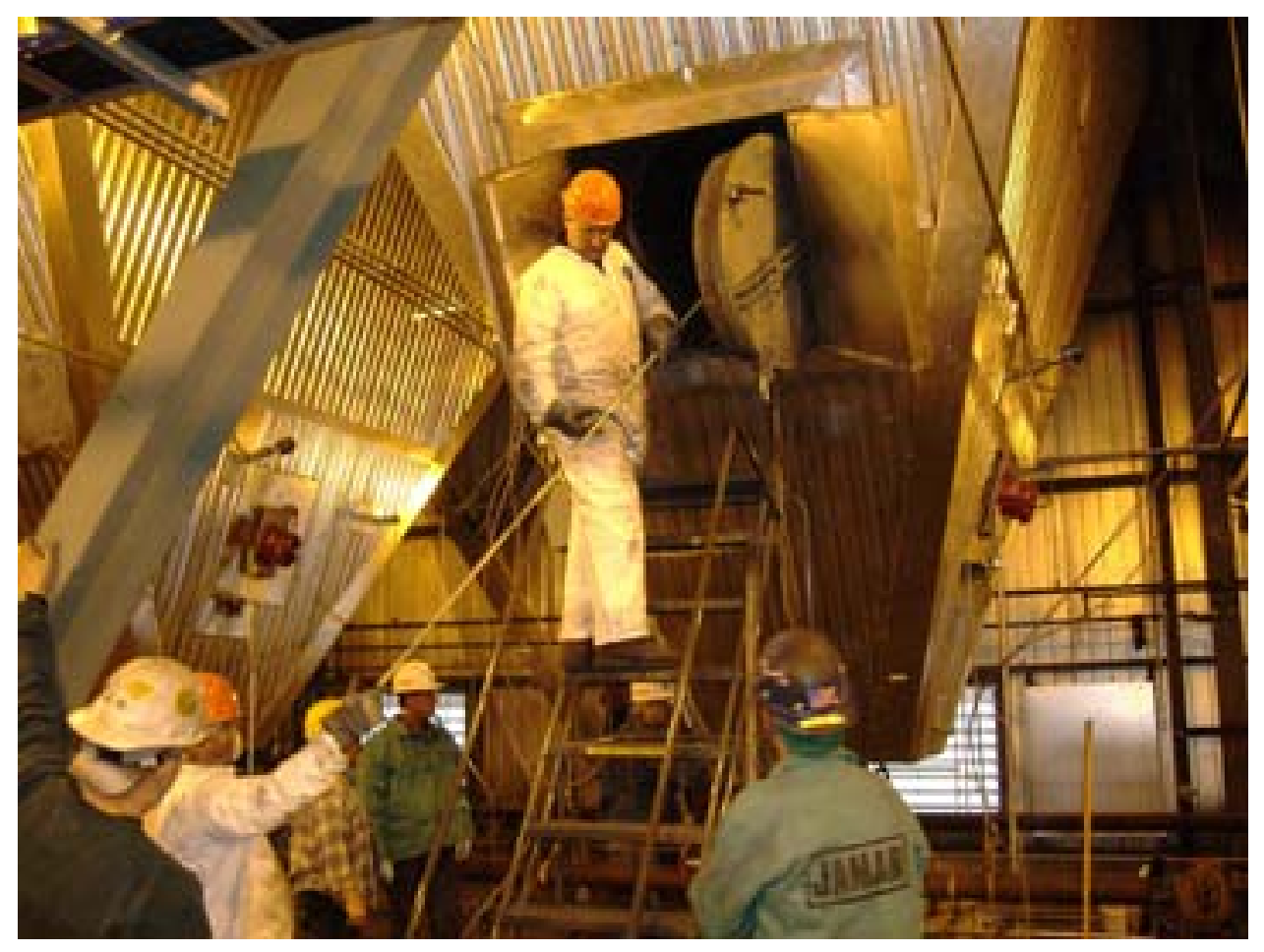

Figure 19. Thermocouples for PAC Bed 


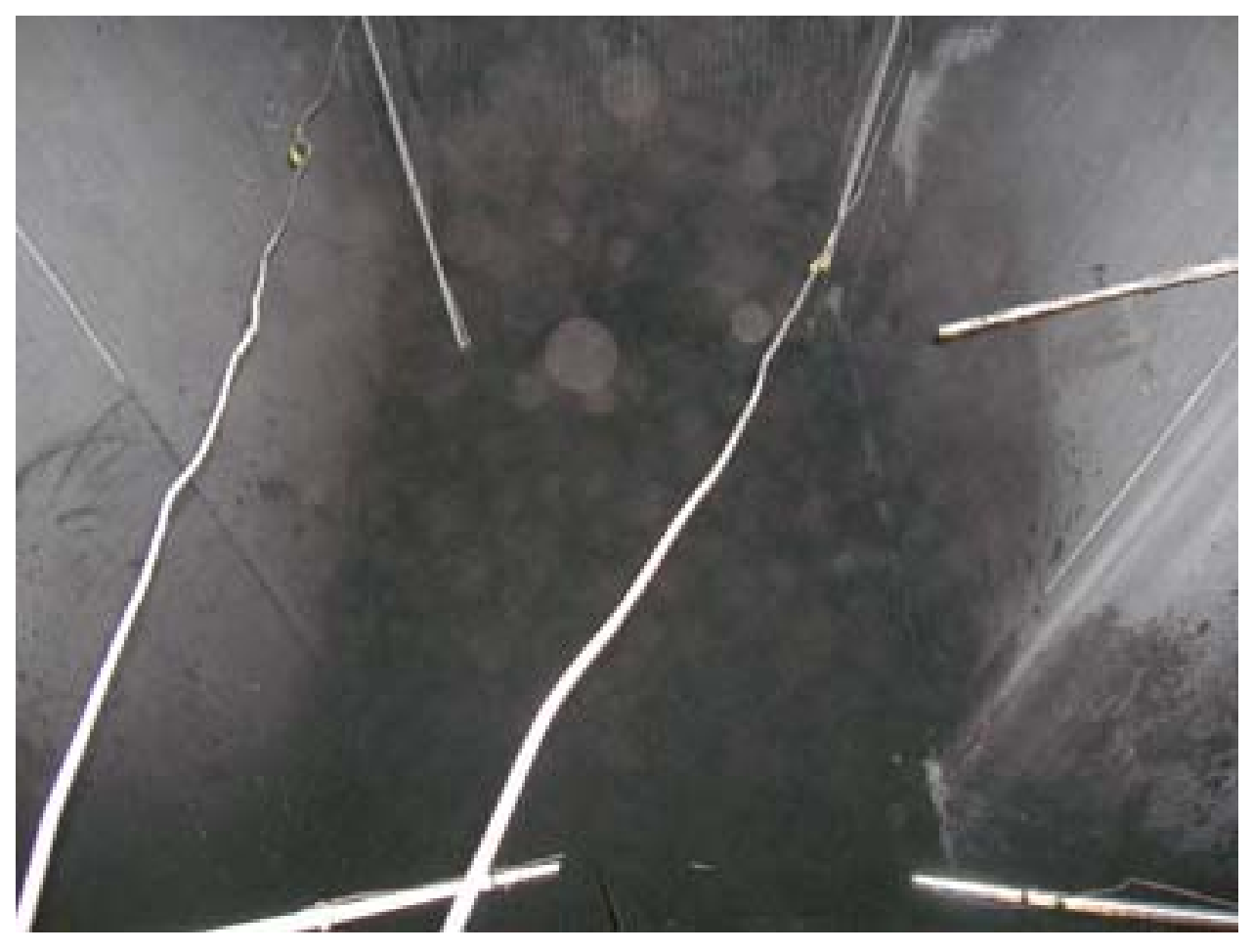

Figure 20. Thermocouples in PAC Bed

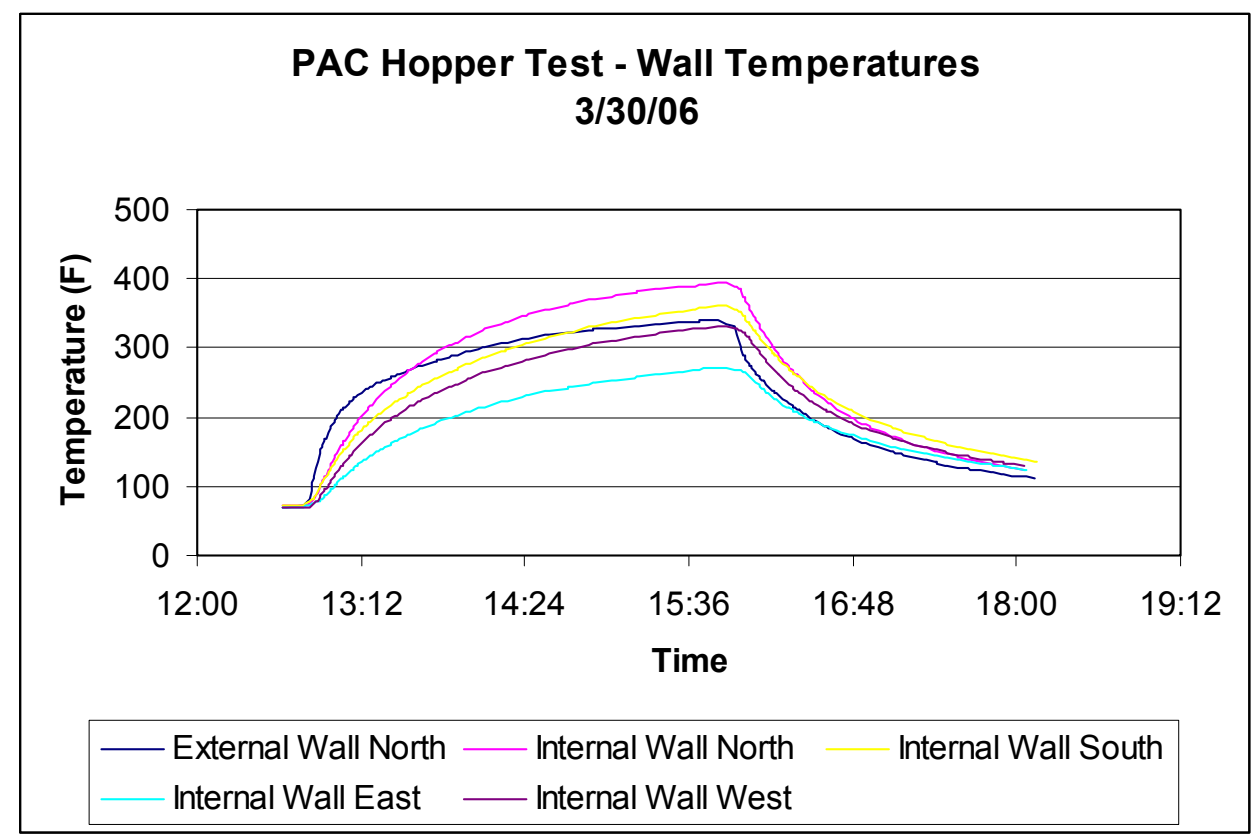

Figure 21. PAC Hopper Test - Inside Wall Temperatures 


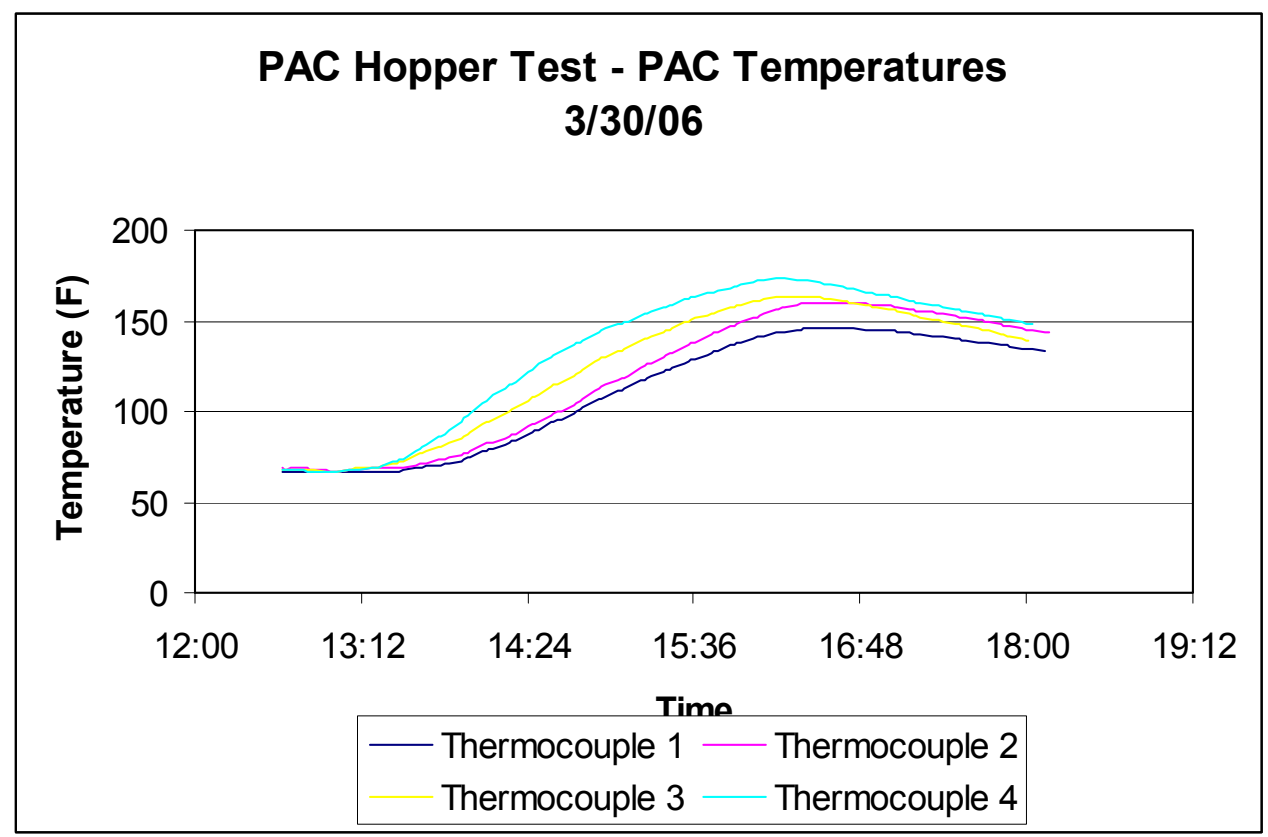

Figure 22. PAC Hopper Test - PAC Bed Temperatures

\section{Mercury Quality Index Test}

\section{Background and Objective}

None of the standard tests used for quality assurance testing of activated carbon are specific to mercury. While putting together the specification for the PAC contract, this deficiency was noted and an effort begun to develop a "Mercury Quality Index" or MQI that can be used by industry.

The overall objective of this effort is to develop a technique to measure the vapor phase mercury sorption capability of activated carbon at conditions that more closely represent the flue gas from utility boilers. To accomplish this, the following objectives must be met:

- Design and test an apparatus consisting of:

- A sorbent test chamber

- A mercury analyzer

- A means of producing a gas stream containing mercury and other important flue gas components.

- Develop a procedure to test various sorbents

\section{Work to Date}

Work began on the MQI apparatus in February 2006. The first step was to develop a design concept. It was decided that the important flue gas components that effect mercury sorption by activated carbon were mercury, sulfur dioxide $\left(\mathrm{SO}_{2}\right)$ and hydrochloric acid $(\mathrm{HCl})$. The 
other parameter that is known to affect mercury sorption is temperature. Using these guidelines, an apparatus was constructed as shown in Figure 23. The main components are:

- Mercury vapor source

$\circ$ Source for $\mathrm{SO}_{2}$ and $\mathrm{HCl}$ gas with the option to selection high and low $\mathrm{SO}_{2}$ values

- Temperature controlled enclosure for the test beds

- Mercury CEM

- Converter to ensure that all mercury from the test beds is converted to elemental mercury

Construction was completed in early March and Norit visited the test site on March 8-9 for a demonstration. Initial trials indicated that modifications were needed to apparatus and further shakedown tests were required to ensure that all components were working properly.

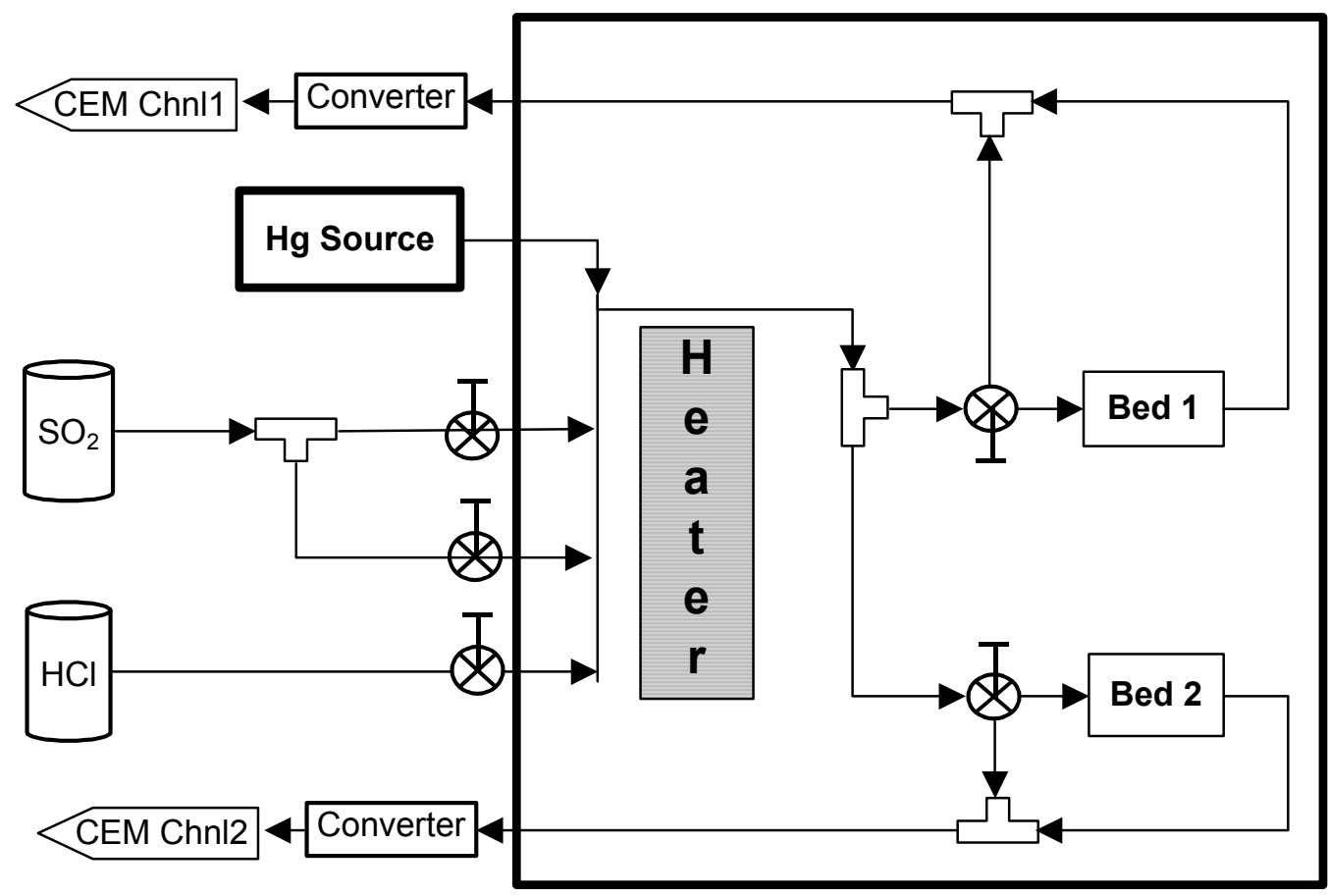

Figure 23. Mercury Quality Index Test Apparatus.

\section{Future Work}

Initial testing indicated that the original flow control devices were oversized so smaller ones have been ordered. Further tests will be conducted in April. 


\section{Task 16 - Operate, Test, Data Analysis and Optimize TOXECONTM for $\mathrm{NO}_{\mathrm{x}}$ and $\mathrm{SO}_{2}$ Control}

No work was done on this task during this period.

\section{Task 17 - Carbon - Ash Management System}

No work was done on this task during this period.

\section{Task 18 - Revise Design Specifications, Prepare O\&M Manuals}

Work was initiated on preparation of C\&B as-built drawings for the project during $1 \mathrm{Q} 06$.

\section{Task 19 - Reporting, Management, Subcontracts, Technology Transfer}

Reports as required in the Financial Assistance Reporting Requirements Checklist and the Statement of Project Objectives are prepared and submitted under this task. Subcontract management, communications, outreach, and technology transfer functions are also performed under this task.

\section{Activity during the Quarter}

- Quarterly Technical Progress Report delivered.

- Quarterly Financial Status Report delivered.

- Quarterly Federal Assistance Program/Project Status Report delivered.

- A poster was updated for the celebration at Presque Isle on April 21, 2006.

- Abstracts were submitted to the Western Coals Conference, POWER-GEN Conference, and MEGA Symposium.

- A presentation was made at the EUEC conference in Tucson in January 2006.

- Technical papers and presentations for future meetings include the MEGA Symposium (August 2006), POWER-GEN (November 2006), and Western Fuels Symposium (October 2006), and $8^{\text {th }}$ International Mercury as a Global Pollutant Conference (August 2006). 


\section{CONCLUSION}

This is the eighth Technical Progress Report under Cooperative Agreement No. DE-FC2604NT41766. All major construction efforts were completed during 4Q05, and only punch list items remained during the current quarter. Work performed on punch list items included: access platform work, insulation, and final cleanup. Demobilization of the majority of the contractors was complete this quarter.

On December 17, the baghouse was put into service with flue gas from Unit 7. Unit 9 was added on January 5 and Unit 8 on January 27, 2006.

Start-up and checkout of the PAC silo was completed this quarter. Calibration of the feeders showed a discrepancy in feed rate from what was initially calculated. The DCS program was adjusted accordingly to provide accurate feed rate control into the ducts.

Baseline tests were performed the week of February 13, 2006. The Ontario Hydro measurements for mercury were in good agreement with the Thermo CEMs. The particulate removal rate across the baghouse was measured at $99.6 \%$, with an emission rate of 0.00011 $\mathrm{lb} / \mathrm{MMBtu}$. As expected, the halogen levels were very low with an average of $3.81 \mathrm{ppm} \mathrm{HCl}$ in the flue gas. Ash and coal samples taken during baseline showed that the ESP ash from units $7-9$ was around $1 \%$ with a mercury level below the detection limit of $10 \mathrm{ng} / \mathrm{g}$. Coal mercury ranged between 35-89 $\mathrm{ng} / \mathrm{g}$ and chlorine levels between $43-116 \mu \mathrm{g} / \mathrm{g}$.

Parametric tests began the week of February 20, 2006. Four injection rates ranging from 0.5$2.0 \mathrm{lb} / \mathrm{MMacf}$ were used for approximately 48 hours each. The mercury removal for these tests was from approximately $38-90 \%$.

On March 1, burning embers were found in the TOXECONTM hoppers. The PAC injection was discontinued and the flue gas diverted from the baghouse to the stack. The hot PAC/ash in each hopper was cooled and removed. Bags were inspected in each compartment for damage. Two compartments had burned bags that had to be replaced; 117 bags in one compartment and 83 in another. None of the other compartments showed damage. Thermogravimetric tests performed on the PAC and PAC/ash mixture showed a heat of combustion of around $850^{\circ} \mathrm{F}$ although smoldering of the PAC occurred at around $780^{\circ} \mathrm{F}$. Column tests performed on PAC using a hot simulated flue gas did not show a heat of adsorption at typical flue gas temperatures. The effect of the hopper heaters was tested in one of the cooled hoppers using $360 \mathrm{lbs}$ of fresh PAC. The temperature of the hopper walls did not exceed $395^{\circ} \mathrm{F}$ after almost 4 hours. This test will be repeated when the baghouse is back in service.

Work continued in the evaluation of components for a mercury continuous emissions monitor system. This c-series CEM was replaced with the upgraded i-series CEM in 4Q05 and an additional i-series CEM was installed at the outlet of the baghouse. The project team is actively involved in a number of reporting and technology transfer activities. 
A Mercury Quality Index apparatus has been designed and fabricated. The objective is to develop a technique to measure the vapor phase mercury sorption capability of activated carbon at conditions representing flue gas in utility boilers. Testing on the apparatus and development of the test procedure will continue in the next quarter. 


\section{Appendix A}

"Copyright (C) 2006 (General Electric Company). This paper was written with support of the U.S. Department of Energy under Contract No. DE-FC26-04NT41766. The Government reserves for itself and others acting on its behalf a royalty-free, nonexclusive, irrevocable, worldwide license for Governmental purposes to publish, distribute, translate, duplicate, exhibit and perform this copyrighted paper." 


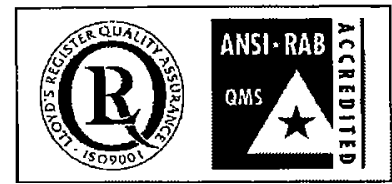

ISO 9001 Accredited Quality System

\section{PARTICULATE AND GASEOUS EMISSIONS STUDY}

Prepared For

ADA-ES, Inc.

Performed At

We Energies

Presque Isle Power Plant

Baghouse Inlet and Outlet

Marquette, Michigan

Test Dates

February 14 through 16, 2006

Report No.

GE Energy Management Services, Inc. Report M22E1184A

Report Submittal Date

April 18, 2006 


\section{GE Energy}

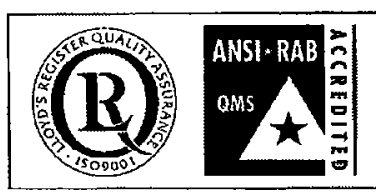

ISO 9001 Accredited Quality System

\section{PARTICULATE AND GASEOUS EMISSIONS STUDY}

Prepared For

ADA-ES, Inc.

Performed At

We Energies

Presque Isle Power Plant

Baghouse Inlet and Outlet

Marquette, Michigan

Test Dates

February 14 through 16, 2006

Report No.

GE Energy Management Services, Inc. Report M22E1184A

Report Submittal Date

April 18, 2006

GE Energy Management Services, Inc. 


\section{GE Energy}

\section{TABLE OF CONTENTS}

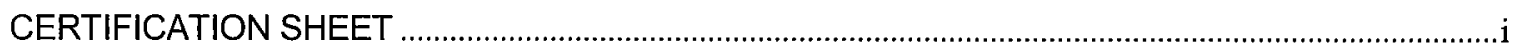

1.0 INTRODUCTION

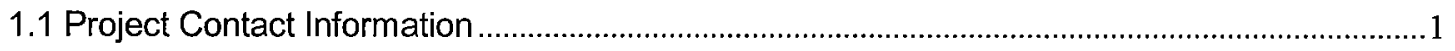

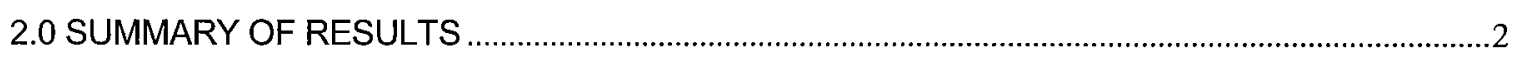

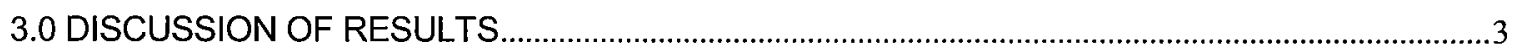

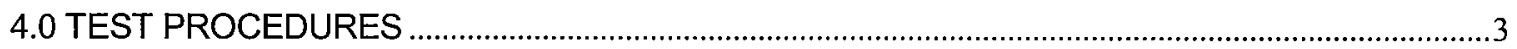

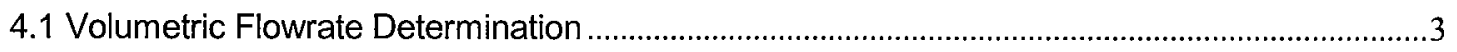

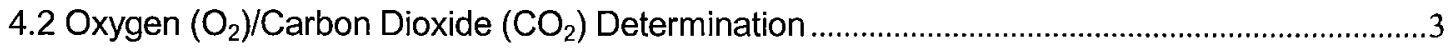

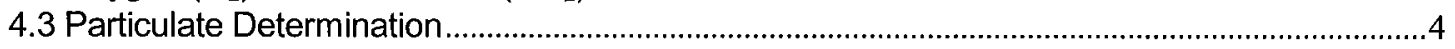

4.4 Speciated Mercury Determination ..............................................................................................

4.5 Hydrogen Halides ( $\mathrm{HCl}, \mathrm{HBr}, \mathrm{HF})$ and Halogens $\left(\mathrm{Cl}_{2}, \mathrm{Br}_{2}\right)$ Determination...............................

4.6 Vapor Phase Mercury Determination - Sorbent Trap Method ....................................................

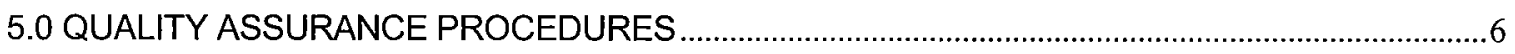

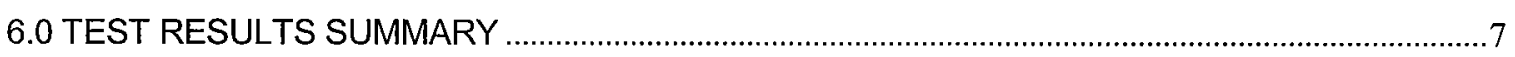

APPENDIX

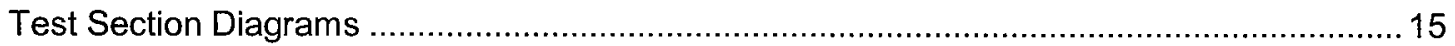

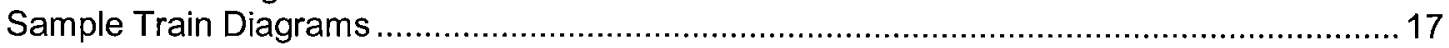

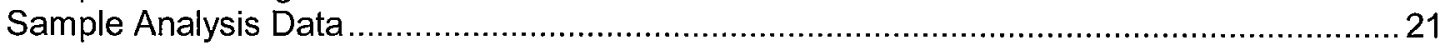

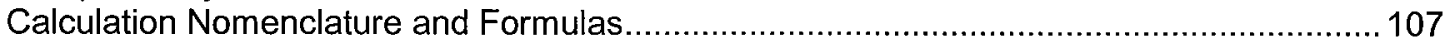

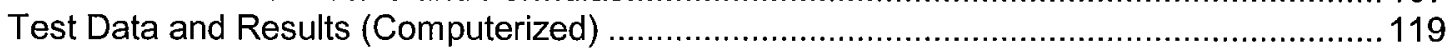

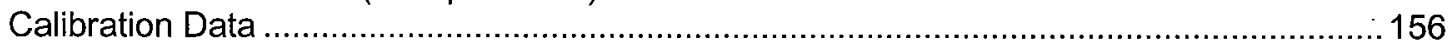

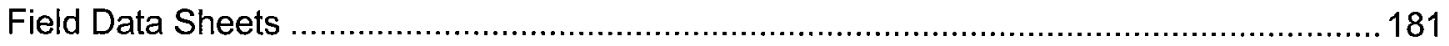




\section{GE Energy}

\section{CERTIFICATION SHEET}

Having reviewed the test program described in this report, I hereby certify the data, information, and results in this report to be accurate and true according to the methods and procedures used.

Data collected under the supervision of others is included in this report and is presumed to have been gathered in accordance with recognized standards.

GE ENERGY MANAGEMENT SERVICES, INC.

Frank H. Jarke

Quality Assurance Manager

(C) 2006, General Electric Company. All rights reserved. The contents of this document are the property of General Electric Company. No part of this work may be reproduced or transmitted in any form or by any means, except as permitted in written license agreement with General Electric Company. General Electric Company has made every reasonable attempt to ensure the completeness and accuracy of this document. The GE logo is a registered trademark of General Electric Company. 


\title{
GE Energy
}

\author{
PARTICULATE AND GASEOUS EMISSIONS STUDY \\ Performed For \\ ADA-ES, Inc. \\ At The \\ We Energies \\ Presque Isle Power Plant \\ Baghouse Inlet and Outlet \\ February 14 through 16,2006
}

\subsection{INTRODUCTION}

GE Energy Management Services, Inc., ("GE Energy") performed a particulate and gaseous emission test program on the Baghouse Inlet and Outlet at the Presque Isle Power Plant of We Energies in Marquette, Michigan on February 14 through 16, 2006. The tests were authorized by We Energies and performed for ADA-ES, Inc.

The purpose of this test program was to determine hydrogen chloride $(\mathrm{HCl})$, bromine $\left(\mathrm{Br}_{2}\right)$, hydrogen bromide $(\mathrm{HBr})$, chlorine $\left(\mathrm{Cl}_{2}\right)$, particulate, mercury and speciated mercury emission rates during normal operating conditions.

\subsection{Project Contact Information}

\begin{tabular}{|l|l|l|}
\hline Location & Address & Contact \\
\hline \hline Test Coordinator & ADA-ES, Inc. & Ms. Robin Stewart \\
& 8100 South Park Way & Senior Project Engineer \\
& Unit B & $303-339-8863$ (phone) \\
& Littleton, Colorado, 80120 & $303-339-0330$ (fax) \\
& & robins@adaes.com (email) \\
\hline Testing Company & GE Energy Management Services, Inc. & Mr. Douglas M. Ryan \\
Representative & 888 Industrial Drive & Project Manager \\
& Elmhurst, Illinois 60126 & $630-530-6640$ (phone) \\
& & $630-530-6630$ (fax) \\
& & douglas.ryan@ge.com \\
\hline
\end{tabular}

The tests were conducted by Messrs. A. Sakellariou, C. Miller, T. Cassin, M. Hamling and D. Ryan of GE Energy. 


\section{GE Energy}

\subsection{SUMMARY OF RESULTS}

The following tables summarizes test results at each of the test locations:

\begin{tabular}{|c|c|c|c|c|}
\hline Parameter & $\begin{array}{l}\text { Reference } \\
\text { Method }\end{array}$ & Units & Common Inlet & Common Outlet \\
\hline \multirow{2}{*}{$\begin{array}{l}\text { Particle Bound } \\
\text { Mercury }\end{array}$} & \multirow[t]{2}{*}{ Ontario Hydro } & $\mathrm{lbs} / \mathrm{hr}$ & 0.00005 & 0.00002 \\
\hline & & $\mathrm{lb} / \mathrm{Tbtu}$ & 0.01589 & 0.00629 \\
\hline \multirow[t]{2}{*}{ Oxidized Mercury } & \multirow[t]{2}{*}{ Ontario Hydro } & $\mathrm{lbs} / \mathrm{hr}$ & 0.00139 & 0.01173 \\
\hline & & $\mathrm{Ib} / \mathrm{Tbtu}$ & 0.43604 & 3.85586 \\
\hline \multirow[t]{2}{*}{ Elemental Mercury } & \multirow[t]{2}{*}{ Ontario Hydro } & lbs/hr & 0.01547 & 0.00160 \\
\hline & & $\mathrm{lb} / \mathrm{Tbtu}$ & 4.72178 & 0.51653 \\
\hline \multirow[t]{2}{*}{ Total Mercury } & \multirow[t]{2}{*}{ Ontario Hydro } & $\mathrm{Ibs} / \mathrm{hr}$ & 0.01692 & 0.01336 \\
\hline & & $\mathrm{Ib} / \mathrm{Tb} t \mathrm{u}$ & 5.29333 & 4.38950 \\
\hline \multirow[t]{2}{*}{$\mathrm{HCl}$} & \multirow[t]{2}{*}{ Method 26A } & $\mathrm{lbs} / \mathrm{hr}$ & -- & 14.9909 \\
\hline & & $\mathrm{lb} / \mathrm{mmBtu}$ & -- & 0.0049 \\
\hline \multirow[t]{2}{*}{$\mathrm{HBr}$} & \multirow[t]{2}{*}{ Method 26A } & $\mathrm{lbs} / \mathrm{hr}$ & -- & 0.4604 \\
\hline & & $\mathrm{lb} / \mathrm{mmBtu}$ & -- & 0.0001 \\
\hline \multirow[t]{2}{*}{$\mathrm{Br}_{2}$} & \multirow[t]{2}{*}{ Method 26A } & $\mathrm{lbs} / \mathrm{hr}$ & -- & 0.0000 \\
\hline & & $\mathrm{lb} / \mathrm{mmBtu}$ & -- & 0.0000 \\
\hline \multirow[t]{2}{*}{$\mathrm{Cl}_{2}$} & \multirow[t]{2}{*}{ Method 26A } & $\mathrm{lbs} / \mathrm{hr}$ & -- & 0.0000 \\
\hline & & $\mathrm{lb} / \mathrm{mmBtu}$ & -- & 0.0000 \\
\hline \multirow{2}{*}{$\begin{array}{c}\text { Filterable } \\
\text { Particulate }\end{array}$} & \multirow[t]{2}{*}{ Method 5} & $\mathrm{lbs} / \mathrm{hr}$ & 110.166 & 1.701 \\
\hline & & $\mathrm{lb} / \mathrm{mmBtu}$ & 0.0347 & 0.0006 \\
\hline
\end{tabular}

\begin{tabular}{|c|c|c|c|c|c|c|}
\hline Parameter & $\begin{array}{c}\text { Reference } \\
\text { Method }\end{array}$ & Units & $\begin{array}{c}\text { Unit 7 } \\
\text { Inlet }\end{array}$ & $\begin{array}{c}\text { Unit 8 } \\
\text { Inlet }\end{array}$ & $\begin{array}{c}\text { Unit 9 } \\
\text { Inlet }\end{array}$ & $\begin{array}{c}\text { Baghouse } \\
\text { Outlet }\end{array}$ \\
\hline \hline $\begin{array}{c}\text { Mercury } \\
\text { (Hg) }\end{array}$ & \multirow{2}{*}{ Method 324 } & $\mathrm{ppm}$ & 0.00010 & 0.00008 & 0.00323 & 0.00054 \\
\cline { 3 - 7 } & $\mathrm{ug} / \mathrm{l}$ & 0.00080 & 0.00212 & 0.02700 & 0.00455 \\
\hline
\end{tabular}

Complete test results for all test locations and parameters are appended in Section 6.0. 


\section{GE Energy}

\subsection{DISCUSSION OF RESULTS}

Source operation appeared normal during the entire test program. Problems were encountered with the M324 sampling trains. At each of the four test locations, it was discovered that significant variation existed from trap to trap. The thin-walled Teflon sleeves used to connect the two glass trap sections and glass liner all fit with varying amounts of resistance. Some traps were very difficult to separate and others separated unintentionally during assembly, and in one case sampling. Once this variation was discovered, every effort was made to check the connections and switch sleeves as needed. However, based on the sample analysis results, it appears that significant in-leakage occurred on many of the tests.

\subsection{TEST PROCEDURES}

All testing, sampling, analytical, and calibration procedures used for this test program were performed as described in the Title 40, Code of Federal Regulations, Part 60 (40CFR60), Appendix A, Methods 1, 2, 3, 5, 26A and 40CFR63 Method 324 and the Ontario Hydro Method. Where applicable, the Quality Assurance Handbook for Air Pollution Measurement Systems, Volume III, Stationary Source Specific Methods, United States Environmental Protection Agency (USEPA) 600/R-94/038c, September 1994 was used to supplement procedures.

\subsection{Volumetric Flowrate Determination}

In order to determine the emission rate on a $\mathrm{lbs} / \mathrm{hr}$ basis, the gas velocities and volumetric flowrates were determined using Method 2, 40CFR60.

Velocity pressures were determined by traversing the test locations with S-type pitot tubes. Temperatures were measured using K-type thermocouples with calibrated digital temperature indicators. The molecular weight and moisture content of the gases were determined to permit the calculation of the volumetric flowrate. Sampling points utilized were determined using Method 1, 40CFR60.

\subsection{Oxygen $\left(\mathrm{O}_{2}\right)$ /Carbon Dioxide $\left(\mathrm{CO}_{2}\right)$ Determination}

Oxygen $\left(\mathrm{O}_{2}\right)$ and carbon dioxide $\left(\mathrm{CO}_{2}\right)$ gas contents were determined in accordance with Method 3, 40CFR60. This method collected samples in a grab manner and analyzed the samples using a Hays Orsat gas analyzer. Several gas extractions were performed during each test run to ensure a stable reading. Mandatory leak checks were performed prior to and following each use. Chemicals are changed frequently and inspected for reactivity prior to each use. 


\section{GE Energy}

\subsection{Particulate Determination}

A total of 24 test points were sampled using six (6) ports at the Baghouse Common Inlet and Outlet test locations.

The particulate sample trains were manufactured by Nutech Corporation of Durham, North Carolina and meet all specifications required by Method 5, 40CFR60. Teflon-lined probes were used. Drawings depicting the sampling ports, test point locations, and sample trains are appended to this report. Velocity pressures were determined simultaneously during sampling with a calibrated S-type pitot tube and inclined manometer. All temperatures were measured using K-type thermocouples with calibrated digital temperature indicators.

The filter media were Whatman 934-AH glass microfibre filters exhibiting a $\geq$ $99.97 \%$ efficiency on 0.3 micron DOP smoke particles in accordance with ASTM Standard Method D-2986-71. All sample contact surfaces of the trains were washed with HPLC reagent-grade acetone. These washes were placed in sealed and marked containers for analysis.

\subsection{Speciated Mercury Determination}

A total of 24 test points were sampled using six (6) ports at the Baghouse Common Inlet and Outlet test locations.

The speciated mercury sample trains were manufactured by Nutech Corporation of Durham, North Carolina and meet all specifications required by The Ontario Hydro Method. Teflon-lined probe were used. Drawings depicting the sampling ports, test point locations, and sample trains are appended to this report. Velocity pressures were determined simultaneously during sampling with a calibrated S-type pitot tube and inclined manometer. All temperatures were measured using K-type thermocouples with calibrated digital temperature indicators.

The filter media were quartz filters exhibiting a $\geq 99.97 \%$ efficiency on 0.3 micron DOP smoke particles in accordance with ASTM Standard Method D-2986-71. All sample contact surfaces of the train were washed with $0.1 \mathrm{~N}$ Nitric Acid. These washes were placed in sealed and marked containers for analysis. All sample recovery of impinger solutions was performed on site.

\subsection{Hydrogen Halides $(\mathrm{HCl}, \mathrm{HBr}, \mathrm{HF})$ and Halogens $\left(\mathrm{Cl}_{2}, \mathrm{Br}_{2}\right)$ Determination}




\section{GE Energy}

Hydrogen chloride $(\mathrm{HCl})$, hydrogen fluoride $(\mathrm{HF})$, hydrogen bromide $(\mathrm{HBr})$, bromine $\left(\mathrm{Br}_{2}\right)$ and chlorine $\left(\mathrm{Cl}_{2}\right)$ concentrations were determined using Method 26A, 40CFR60. An integrated twenty-four-point sample was extracted from the common outlet gas stream and passed through $0.1 \mathrm{~N}$ sulfuric acid $\left(\mathrm{H}_{2} \mathrm{SO}_{4}\right)$ and $0.1 \mathrm{~N}$ sodium hydroxide $(\mathrm{NaOH})$. The samples were then analyzed by ion chromatography. The sample train consisted of a heated glass probe liner, a heated filter, and six impingers. The first impinger was short stemmed and empty to knock out heavy moisture, the second and third impingers contained the dilute sulfuric acid, the fourth and fifth impingers contained a $0.1 \mathrm{~N}$ sodium hydroxide $(\mathrm{NaOH})$ scrubber solution to remove any remaining chlorine, and the sixth impinger contained silica gel to absorb any remaining moisture. The train was leak checked prior to and after each run. The sample was then extracted isokinetically. The samples were recovered by quantitatively transferring the contents of the first three impingers (the knock out and the two acidic absorbing solution impingers) and deionized water rinses to a glass sample jar. Impingers 4 and 5 (alkaline absorbing solution) and deionized water rinses were transferred to a separate glass sample jar. The samples were labeled, and the level marked for transfer to the laboratory. The samples were then analyzed by ion chromatography.

The test trains were weighed before and after each test for moisture determination.

The test crew performed sample recovery at the test site and initial analysis was performed on site. Samples were transported to an approved lab for final analysis. Copies of all sample analysis sheets are appended to this report.

\subsection{Vapor Phase Mercury Determination - Sorbent Trap Method}

Mercury emissions were determined in accordance with USEPA Draft Method 324. A single point was used for paired train sorbent sampling at baghouse inlets $7,8 \& 9$ and the common baghouse outlet.

Sorbent traps included main and backup sections in series for collection of $\mathrm{Hg}$.

The sorbent trap was supported on a probe and inserted directly into the flue gas stream. No heating of the probe was required as duct temperatures were within the specified $200^{\circ}$ to $375^{\circ} \mathrm{F}$. range. Sampling was performed at a constant rate of (approximately 0.4 liters $/ \mathrm{min}$ ) for a period of two hours.

After sampling, sorbent traps were removing from the probe, both ends were plugged, and traps were then placed into clean sample storage containers. 


\section{GE Energy}

Each trap was then acid leached and the resulting leachate analyzed by cold vapor atomic fluorescence spectrometry (CVAFS) detection.

Copies of all sample analysis sheets are appended to this report.

Calculations were performed on a computer and by hand. An explanation of the nomenclature and calculations along with the complete test results are appended. Also appended are the calibration data and copies of the raw field data sheets.

Raw data are kept on file at the GE Energy office in Elmhurst, Illinois. All samples from this test program (not already used in analysis) will be retained for 60 days after the submittal of the report, after which they will be discarded unless GE Energy is advised otherwise.

\subsection{QUALITY ASSURANCE PROCEDURES}

GE Energy recognizes the previously described reference methods to be very technique oriented and attempts to minimize all factors which can increase error by implementing its Quality Assurance Program into every segment of its testing activities.

Shelf life of chemical reagents prepared at the GE Energy laboratory or at the jobsite did not exceed those specified in the above mentioned methods; and, those reagents having a shelf life of one week were prepared daily at the jobsite. When on-site analyses were required, all reagent standardizations were performed daily by the same person performing the analysis.

Dry and wet test meters were calibrated according to methods described in the Quality Assurance Handbook, Sections 3.3.2, 3.4.2 and 3.5.2. Percent error for the wet test meter according to the methods was less than the allowable error of 1.0 percent. The dry test meters measured the test sample volumes to within 2 percent at the flowrate and conditions encountered during sampling. 


\section{GE Energy}

\subsection{TEST RESULTS SUMMARY}




\section{GE Energy}

\section{PARTICULATE TEST RESULTS SUMMARY}

$\begin{array}{ll}\text { Company: } & \text { We Energies } \\ \text { Plant: } & \text { Presque Isle Power Plant } \\ \text { Unit: } & \text { Baghouse Inlet }\end{array}$

\begin{tabular}{|l|c|c|c|c|}
\hline Test Run Number & $\mathbf{1}$ & $\mathbf{2}$ & $\mathbf{3}$ & Average \\
\hline Source Condition & Normal & Normal & Normal & \\
\hline Date & $02 / 16 / 2006$ & $02 / 16 / 2006$ & $02 / 16 / 2006$ & \\
\hline Start Time & $8: 30$ & $11: 20$ & $14: 00$ & \\
\hline End Time & $9: 54$ & $13: 12$ & $15: 17$ & \\
\hline Filterable PM: & 0.0142 & 0.0174 & 0.0235 & 0.0183 \\
\hline grains/dscf & 84.868 & 104.438 & 141.192 & 110.166 \\
\hline lb/hr & 0.0270 & 0.0329 & 0.0442 & 0.0347 \\
\hline Ib/mmBtu & \multicolumn{5}{|l|}{} \\
\hline Stack Parameters: & $1,238,832$ & $1,232,324$ & $1,224,983$ & $1,232,047$ \\
\hline Gas Volumetric Flow Rate, acfm & 699,058 & 701,495 & 702,104 & 700,886 \\
\hline Gas Volumetric Flow Rate, dscfm & 337.3 & 331.3 & 333.3 & 334.0 \\
\hline Average Gas Temperature, ${ }^{\circ} \mathrm{F}$ & 61.268 & 60.947 & 60.584 & 60.933 \\
\hline Average Gas Velocity, ft/sec & 11.6 & 11.5 & 10.7 & 11.3 \\
\hline Flue Gas Moisture, percent by volume & 28.84 & 28.84 & 28.84 & \\
\hline Average Flue Pressure, in. $\mathrm{Hg}$ & 29.32 & 29.32 & 29.32 & \\
\hline Barometric Pressure, in. Hg & 13.6 & 13.8 & 13.8 & 13.7 \\
\hline Average \%CO ${ }_{2}$ by volume, dry basis & 5.6 & 5.5 & 5.4 & 5.5 \\
\hline Average \% $\mathrm{O}_{2}$ by volume, dry basis & 30.400 & 30.428 & 30.424 & \\
\hline Dry Molecular Wt. of Gas, lb/lb-mole & 39.763 & 41.753 & 39.855 & \\
\hline Gas Sample Volume, dscf & 101.8 & 106.5 & 101.5 & \\
\hline Isokinetic Variance & & & & \\
\hline
\end{tabular}




\section{GE Energy}

\section{SPECIATED MERCURY TEST RESULTS SUMMARY}

$\begin{array}{ll}\text { Company: } & \text { ADA-ES } \\ \text { Plant: } & \text { We Energies - Presque Isle } \\ \text { Unit: } & \text { Baghouse Inlet }\end{array}$

\begin{tabular}{|c|c|c|c|c|}
\hline Test Run Number & 1 & 2 & 3 & Average \\
\hline Source Condition & Normal & Normal & Normal & \\
\hline Date & $02 / 14 / 2006$ & $02 / 14 / 2006$ & $02 / 14 / 2006$ & \\
\hline Start Time & $9: 25$ & $12: 35$ & $15: 30$ & \\
\hline End Time & $12: 03$ & $14: 56$ & $17: 48$ & \\
\hline \multicolumn{5}{|l|}{ Particle Bound Mercury Emissions } \\
\hline $\mathrm{ppm}$ & 0.000005 & 0.000000 & 0.000002 & 0.000002 \\
\hline $\mathrm{ug} / \mathrm{dscm}$ & 0.04 & 0.00 & 0.02 & 0.02 \\
\hline $\mathrm{lb} / \mathrm{hr}$ & 0.00011 & 0.00000 & 0.00004 & 0.00005 \\
\hline $\mathrm{lb} / \mathrm{mmBtu}$ & 0.00000003 & 0.00000000 & 0.00000001 & 0.00000002 \\
\hline $\mathrm{lb} / \mathrm{Tbtu}$ & 0.03438 & 0.00000 & 0.01328 & 0.01589 \\
\hline \multicolumn{5}{|l|}{ Elemental Mercury Emissions } \\
\hline ppm & 0.000684 & 0.000687 & 0.000730 & 0.000700 \\
\hline $\mathrm{ug} / \mathrm{dscm}$ & 5.71 & 5.73 & 6.09 & 5.84 \\
\hline $\mathrm{lb} / \mathrm{hr}$ & 0.01510 & 0.01523 & 0.01609 & 0.01547 \\
\hline $\mathrm{lb} / \mathrm{mmBtu}$ & 0.0000047 & 0.0000047 & 0.0000047 & 0.0000047 \\
\hline $\mathrm{lb} / \mathrm{Tbtu}$ & 4.72732 & 4.71901 & 4.71901 & 4.72178 \\
\hline \multicolumn{5}{|l|}{ Oxidized Mercury Emissions } \\
\hline $\mathrm{ppm}$ & 0.000068 & 0.000064 & 0.000057 & 0.000063 \\
\hline $\mathrm{ug} / \mathrm{dscm}$ & 0.57 & 0.53 & 0.48 & 0.53 \\
\hline $\mathrm{lb} / \mathrm{hr}$ & 0.00151 & 0.00141 & 0.00126 & 0.00139 \\
\hline $\mathrm{lb} / \mathrm{mmBtu}$ & 0.0000005 & 0.0000004 & 0.0000004 & 0.0000004 \\
\hline $\mathrm{lb} / \mathrm{Tb} t \mathrm{u}$ & 0.47273 & 0.43695 & 0.39844 & 0.43604 \\
\hline \multicolumn{5}{|l|}{ Total Mercury Emissions } \\
\hline $\mathrm{ppm}$ & 0.000757 & 0.000750 & 0.000789 & 0.000765 \\
\hline $\mathrm{ug} / \mathrm{dscm}$ & 6.32 & 6.26 & 6.58 & 6.39 \\
\hline $\mathrm{lb} / \mathrm{hr}$ & 0.01672 & 0.01664 & 0.01740 & 0.01692 \\
\hline $\mathrm{lb} / \mathrm{mmBtu}$ & 0.0000052 & 0.0000052 & 0.0000055 & 0.0000053 \\
\hline $\mathrm{lb} / \mathrm{Tb} \mathrm{tu}$ & 5.23444 & 5.15596 & 5.48958 & 5.29333 \\
\hline \multicolumn{5}{|l|}{ Stack Parameters: } \\
\hline Average Gas Temperature, ${ }^{\circ} \mathrm{F}$ & 331.5 & 331.3 & 331.4 & 331.4 \\
\hline Average Gas Velocity, $\mathrm{ft} / \mathrm{sec}$ & 61.623 & 61.683 & 61.582 & 61.629 \\
\hline Flue Gas Moisture, percent by volume & 10.6 & 10.3 & 10.6 & 10.5 \\
\hline Average Flue Pressure, in. $\mathrm{Hg}$ & 28.44 & 28.44 & 28.44 & \\
\hline Barometric Pressure, in. $\mathrm{Hg}$ & 28.95 & 28.95 & 28.95 & \\
\hline Average $\% \mathrm{CO}_{2}$ by volume, dry basis & 13.6 & 13.8 & 13.8 & 13.7 \\
\hline Average $\% \mathrm{O}_{2}$ by volume, dry basis & 5.5 & 5.4 & 5.6 & 5.5 \\
\hline Dry Molecular Wt. of Gas, Ib/lb-mole & 30.396 & 30.424 & 30.432 & \\
\hline Gas Sample Volume, dscf & 68.089 & 66.537 & 66.529 & \\
\hline Isokinetic Variance & 102.6 & 99.9 & 100.4 & \\
\hline
\end{tabular}




\section{GE Energy}

\section{PARTICULATE TEST RESULTS SUMMARY}

$\begin{array}{ll}\text { Company: } & \text { We Energies } \\ \text { Plant: } & \text { Presque Isle Power Plant } \\ \text { Unit: } & \text { Baghouse Outlet }\end{array}$

\begin{tabular}{|c|c|c|c|c|}
\hline Test Run Number & 1 & 2 & 3 & Average \\
\hline Source Condition & Base-Load & Base-Load & Base-Load & \\
\hline Date & $02 / 16 / 2006$ & $02 / 16 / 2006$ & $02 / 16 / 2006$ & \\
\hline Start Time & $8: 30$ & $11: 20$ & $14: 00$ & \\
\hline End Time & 9:55 & $12: 45$ & $15: 25$ & \\
\hline \multicolumn{5}{|l|}{ Filterable PM: } \\
\hline grains/dscf & 0.0007 & 0.0001 & 0.0001 & 0.0003 \\
\hline $\mathrm{lb} / \mathrm{hr}$ & 4.179 & 0.368 & 0.556 & 1.701 \\
\hline $\mathrm{lb} / \mathrm{mmBtu}$ & 0.0014 & 0.0001 & 0.0002 & 0.0006 \\
\hline \multicolumn{5}{|l|}{ Stack Parameters: } \\
\hline Gas Volumetric Flow Rate, acfm & $1,167,586$ & $1,163,998$ & $1,169,827$ & $1,167,137$ \\
\hline Gas Volumetric Flow Rate, dscfm & 691,212 & 688,582 & 698,186 & 692,660 \\
\hline Average Gas Temperature, ${ }^{\circ} \mathrm{F}$ & 337.8 & 330.7 & 331.5 & 333.3 \\
\hline Average Gas Velocity, $\mathrm{ft} / \mathrm{sec}$ & 61.079 & 60.891 & 61.196 & 61.056 \\
\hline Flue Gas Moisture, percent by volume & 9.7 & 10.5 & 9.6 & 9.9 \\
\hline Average Flue Pressure, in. $\mathrm{Hg}$ & 29.62 & 29.62 & 29.62 & \\
\hline Barometric Pressure, in. $\mathrm{Hg}$ & 29.40 & 29.40 & 29.40 & \\
\hline Average $\% \mathrm{CO}_{2}$ by volume, dry basis & 13.1 & 13.2 & 13.1 & 13.1 \\
\hline Average $\% \mathrm{O}_{2}$ by volume, dry basis & 5.7 & 5.8 & 5.8 & 5.8 \\
\hline Dry Molecular Wt. of Gas, 1b/lb-mole & 30.324 & 30.344 & 30.328 & \\
\hline Gas Sample Volume, dscf & 50.312 & 49.443 & 49.800 & \\
\hline Isokinetic Variance & 104.9 & 103.5 & 102.8 & \\
\hline
\end{tabular}




\section{GE Energy}

\begin{tabular}{|c|c|c|c|c|c|}
\hline \multicolumn{6}{|c|}{ HALOGEN TEST RESULTS SUMMARY } \\
\hline Company: & \multicolumn{5}{|l|}{ We Energies } \\
\hline Plant: & \multicolumn{5}{|c|}{ Presque Isle Power Plant } \\
\hline Unit: & \multicolumn{5}{|l|}{ Baghouse Outlet } \\
\hline \multicolumn{2}{|c|}{ Test Run Number } & 1 & 2 & 3 & Average \\
\hline \multicolumn{2}{|c|}{ Source Condition } & Base-Load & Base-Load & Base-Load & \\
\hline \multicolumn{2}{|l|}{ Date } & $02 / 16 / 2006$ & $02 / 16 / 2006$ & $02 / 16 / 2006$ & \\
\hline \multicolumn{2}{|l|}{ Start Time } & $8: 30$ & 11:20 & 14:00 & \\
\hline \multicolumn{2}{|l|}{ End Time } & 9:55 & $12: 45$ & $15: 25$ & \\
\hline \multicolumn{6}{|c|}{ HCl Emissions: } \\
\hline \multicolumn{2}{|l|}{ ppm: } & 3.79 & 3.90 & 3.73 & 3.81 \\
\hline \multicolumn{2}{|l|}{$\mathrm{lb} / \mathrm{hr}$} & 14.9018 & 15.2718 & 14.7991 & 14.9909 \\
\hline \multicolumn{2}{|l|}{$\mathrm{lb} / \mathrm{mmBtu}$} & 0.0048 & 0.0050 & 0.0048 & 0.0049 \\
\hline \multicolumn{6}{|c|}{ HBr Emissions: } \\
\hline \multicolumn{2}{|l|}{ ppm: } & 0.16 & 0.00 & 0.00 & 0.05 \\
\hline \multicolumn{2}{|l|}{$\mathrm{lb} / \mathrm{hr}$} & 1.3811 & 0.0000 & 0.0000 & 0.4604 \\
\hline \multicolumn{2}{|l|}{$\mathrm{lb} / \mathrm{mmBtu}$} & 0.0004 & 0.0000 & 0.0000 & 0.0001 \\
\hline \multicolumn{6}{|c|}{$\mathrm{Cl}_{2}$ Emissions: } \\
\hline \multicolumn{2}{|l|}{ ppm: } & 0.00 & 0.00 & 0.00 & 0.00 \\
\hline \multicolumn{2}{|l|}{$\mathrm{lb} / \mathrm{hr}$} & 0.0000 & 0.0000 & 0.0000 & 0.0000 \\
\hline \multicolumn{2}{|l|}{$\mathrm{lb} / \mathrm{mmBtu}$} & 0.0000 & 0.0000 & 0.0000 & 0.0000 \\
\hline \multicolumn{6}{|c|}{$\mathrm{Br}_{2}$ Emissions: } \\
\hline \multicolumn{2}{|l|}{ ppm: } & 0.00 & 0.00 & 0.00 & 0.00 \\
\hline \multicolumn{2}{|l|}{$\mathrm{lb} / \mathrm{hr}$} & 0.0000 & 0.0000 & 0.0000 & 0.0000 \\
\hline \multicolumn{2}{|l|}{$\mathrm{lb} / \mathrm{mmBtu}$} & 0.0000 & 0.0000 & 0.0000 & 0.0000 \\
\hline \multicolumn{6}{|c|}{ Stack Parameters: } \\
\hline \multicolumn{2}{|c|}{ Gas Volumetric Flow Rate, acfm } & $1,167,586$ & $1,163,998$ & $1,169,827$ & $1,167,137$ \\
\hline Gas Volumet & Flow Rate, dscfm & 691,212 & 688,582 & 698,186 & 692,660 \\
\hline Average Gas & emperature, ${ }^{\circ} \mathrm{F}$ & 337.8 & 330.7 & 331.5 & 333.3 \\
\hline Average Gas & elocity, $\mathrm{ft} / \mathrm{sec}$ & 61.079 & 60.891 & 61.196 & 61.056 \\
\hline Flue Gas Mo & ure, percent by volume & 9.7 & 10.5 & 9.6 & 9.9 \\
\hline Average Flue & ressure, in. $\mathrm{Hg}$ & 29.62 & 29.62 & 29.62 & \\
\hline Barometric $\mathrm{P}$ & ssure, in. $\mathrm{Hg}$ & 29.40 & 29.40 & 29.40 & \\
\hline Average $\% \mathrm{C}$ & by volume, dry basis & 13.1 & 13.2 & 13.1 & 13.1 \\
\hline Average $\% \mathrm{O}$ & y volume, dry basis & 5.7 & 5.8 & 5.8 & 5.8 \\
\hline Dry Molecul & Wt. of Gas, lb/lb-mole & 30.324 & 30.344 & 30.328 & \\
\hline Gas Sample & lume, dscf & 50.312 & 49.443 & 49.800 & \\
\hline Isokinetic Va & ince & 104.9 & 103.5 & 102.8 & \\
\hline
\end{tabular}




\section{GE Energy}

SPECIATED MERCURY TEST RESULTS SUMMARY

$\begin{array}{ll}\text { Company: } & \text { ADA-ES } \\ \text { Plant: } & \text { We Energies - Presque Isle } \\ \text { Unit: } & \text { Baghouse Outlet }\end{array}$

\begin{tabular}{|c|c|c|c|c|}
\hline Test Run Number & 1 & 2 & 3 & Average \\
\hline Source Condition & Base-Load & Base-Load & Base-Load & \\
\hline Date & $02 / 14 / 2006$ & $02 / 14 / 2006$ & $02 / 14 / 2006$ & \\
\hline Start Time & $9: 25$ & $12: 35$ & $15: 30$ & \\
\hline End Time & $11: 52$ & $14: 55$ & $17: 48$ & \\
\hline \multicolumn{5}{|l|}{ Particle Bound Mercury Emissions } \\
\hline $\mathrm{ppm}$ & 0.000001 & 0.000001 & 0.000001 & 0.000001 \\
\hline $\mathrm{ug} / \mathrm{dscm}$ & 0.01 & 0.01 & 0.00 & 0.01 \\
\hline $\mathrm{lb} / \mathrm{hr}$ & 0.00002 & 0.00002 & 0.00001 & 0.00002 \\
\hline $\mathrm{lb} / \mathrm{mmBtu}$ & 0.0000000 & 0.0000000 & 0.0000000 & 0.0000000 \\
\hline $1 \mathrm{~b} /$ Tbtu & 0.00756 & 0.00756 & 0.00374 & 0.00629 \\
\hline \multicolumn{5}{|l|}{ Elemental Mercury Emissions } \\
\hline $\mathrm{ppm}$ & 0.000070 & 0.000075 & 0.000080 & 0.000075 \\
\hline $\mathrm{ug} / \mathrm{dscm}$ & 0.59 & 0.63 & 0.66 & 0.63 \\
\hline $\mathrm{lb} / \mathrm{hr}$ & 0.00151 & 0.00160 & 0.00170 & 0.00160 \\
\hline $\mathrm{lb} / \mathrm{mmBtu}$ & 0.0000005 & 0.0000005 & 0.0000005 & 0.0000005 \\
\hline $\mathrm{Ib} / \mathrm{Tbtu}$ & 0.49161 & 0.52899 & 0.52899 & 0.51653 \\
\hline \multicolumn{5}{|l|}{ Oxidized Mercury Emissions } \\
\hline $\mathrm{ppm}$ & 0.000524 & 0.000589 & 0.000531 & 0.000548 \\
\hline $\mathrm{ug} / \mathrm{dscm}$ & 4.37 & 4.92 & 4.43 & 4.57 \\
\hline $\mathrm{lb} / \mathrm{hr}$ & 0.01124 & 0.01261 & 0.01135 & 0.01173 \\
\hline $\mathrm{lb} / \mathrm{mmBtu}$ & 0.0000037 & 0.0000042 & 0.0000037 & 0.0000039 \\
\hline $\mathrm{lb} / \mathrm{Tbtu}$ & 3.66814 & 4.15637 & 3.74307 & 3.85586 \\
\hline \multicolumn{5}{|l|}{ Total Mercury Emissions } \\
\hline ppm & 0.000595 & 0.000665 & 0.000611 & 0.000624 \\
\hline $\mathrm{ug} / \mathrm{dscin}$ & 4.96 & 5.55 & 5.10 & 5.21 \\
\hline $\mathrm{lb} / \mathrm{hr}$ & 0.01278 & 0.01423 & 0.01307 & 0.01336 \\
\hline $\mathrm{lb} / \mathrm{mmBtu}$ & 0.0000042 & 0.0000047 & 0.0000043 & 0.0000044 \\
\hline $\mathrm{lb} /$ Tbtu & 4.16731 & 4.69292 & 4.30827 & 4.38950 \\
\hline \multicolumn{5}{|l|}{ Stack Parameters: } \\
\hline Average $\mathrm{G}$ as Temperature, ${ }^{\circ} \mathrm{F}$ & 331.7 & 331.9 & 334.8 & 332.8 \\
\hline A verage Gas Velocity, $\mathrm{ft} / \mathrm{sec}$ & 60.893 & 61.315 & 61.541 & 61.250 \\
\hline Flue Gas Moisture, percent by volume & 9.0 & 10.0 & 10.0 & 9.7 \\
\hline A verage Flue Pressure, in. $\mathrm{Hg}$ & 29.11 & 29.11 & 29.11 & \\
\hline Barometric Pressure, in. $\mathrm{Hg}$ & 28.89 & 28.89 & 28.89 & \\
\hline Average $\% \mathrm{CO}_{2}$ by volume, dry basis & 13.4 & 13.3 & 13.2 & 13.3 \\
\hline Average $\% \mathrm{O}_{2}$ by volume, dry basis & 5.7 & 5.8 & 5.8 & 5.8 \\
\hline Dry Molecular Wt. of Gas, lb/lb-mole & 30.372 & 30.360 & 30.344 & \\
\hline Gas Sample Volume, dscf & 78.397 & 78.981 & 79.729 & \\
\hline Isokinetic Variance & 101.5 & 102.7 & 103.7 & \\
\hline
\end{tabular}




\title{
GE Energy
}

\author{
We Energies \\ Presque Isle Power Plant \\ February 15, 2006
}

Method 324 Test Result Summary

\begin{tabular}{|c|c|c|c|c|c|c|c|c|c|c|c|c||}
\hline \multirow{2}{*}{ Unit } & \multicolumn{4}{|c|}{ Unit 7 Inlet } & \multicolumn{4}{c|}{ Unit 8 Inlet } & \multicolumn{4}{c||}{ Unit 9 Inlet } \\
\cline { 2 - 13 } & Test 1 & Test 2 & Test 3 & Average & Test 1 & Test 2 & Test 3 & Average & Test 1 & Test 2 & Test 3 & Average \\
\hline \hline Hg ppm & 0.00012 & 0.00009 & 0.00008 & 0.00010 & 0.00009 & 0.00007 & 0.00007 & 0.00008 & 0.00211 & 0.00550 & 0.00210 & 0.00323 \\
\hline Hg ugl & 0.00096 & 0.00074 & 0.00070 & 0.00080 & 0.00073 & 0.00061 & 0.00501 & 0.00212 & 0.01758 & 0.04589 & 0.01752 & 0.02700 \\
\hline \hline
\end{tabular}

\begin{tabular}{|c|c|c|c|c|c|}
\hline \multirow{2}{*}{ Unit } & \multicolumn{5}{|c|}{ Baghouse Outlet } \\
\cline { 2 - 6 } & Test 1 $^{\star}$ & Test 2 & Test 3 & Test 4 & Average \\
\hline \hline Hg ppm & 0.00072 & 0.00034 & 0.00063 & 0.00066 & 0.00054 \\
\hline Hg ugll & 0.00597 & 0.00287 & 0.00524 & 0.00554 & 0.00455 \\
\hline \hline
\end{tabular}

* Test 1 is not included in average 
APPENDIX 


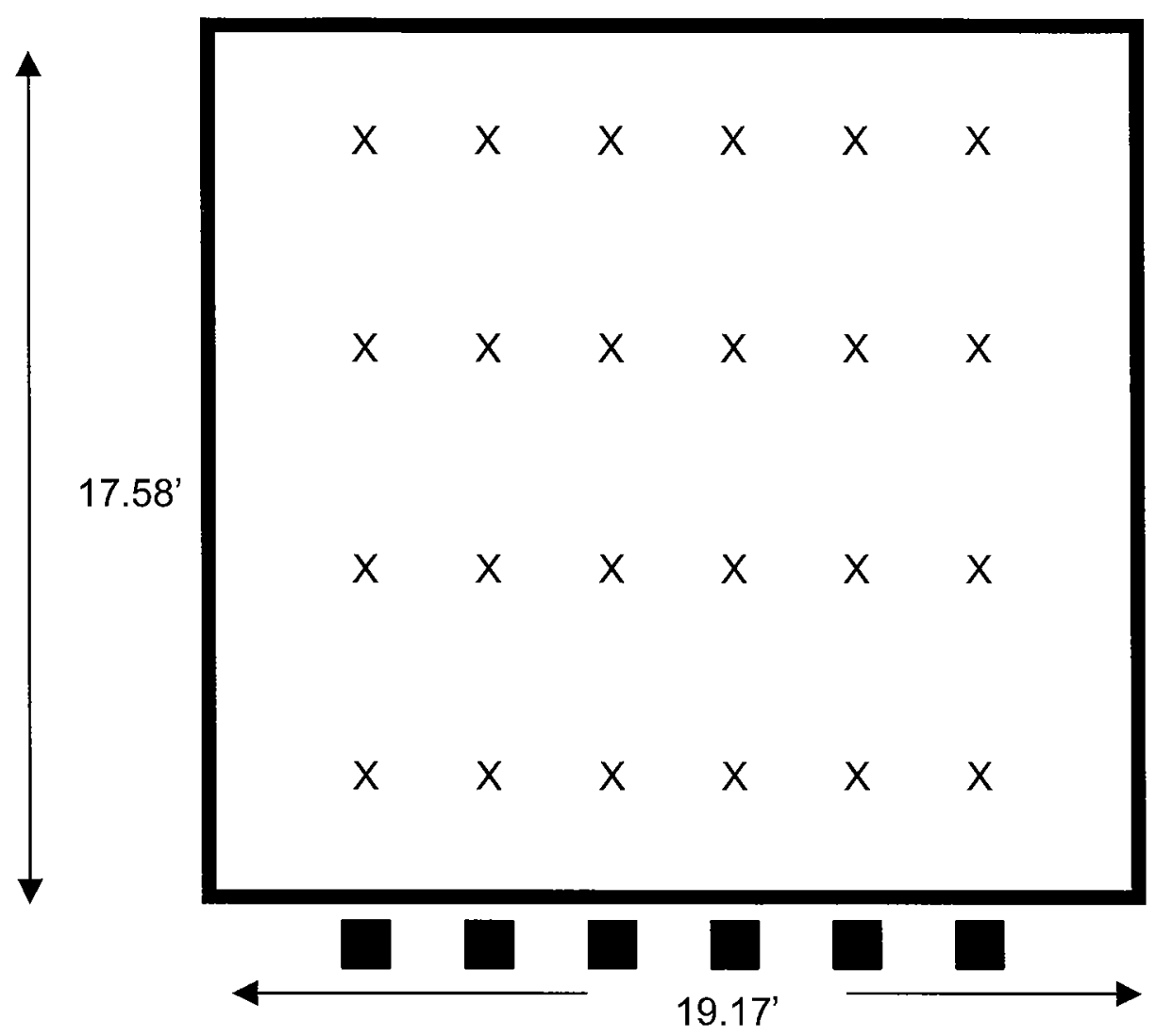

Job: We Energies

Marquette, Michigan

Date: February 14 through 16, 2006

Area: 336.996 Square Feet

Test Location: Baghouse Inlet No. Test Ports: 4

Length: 17.58 Feet Tests Points per Port: 6

Width: 19.17 Feet 


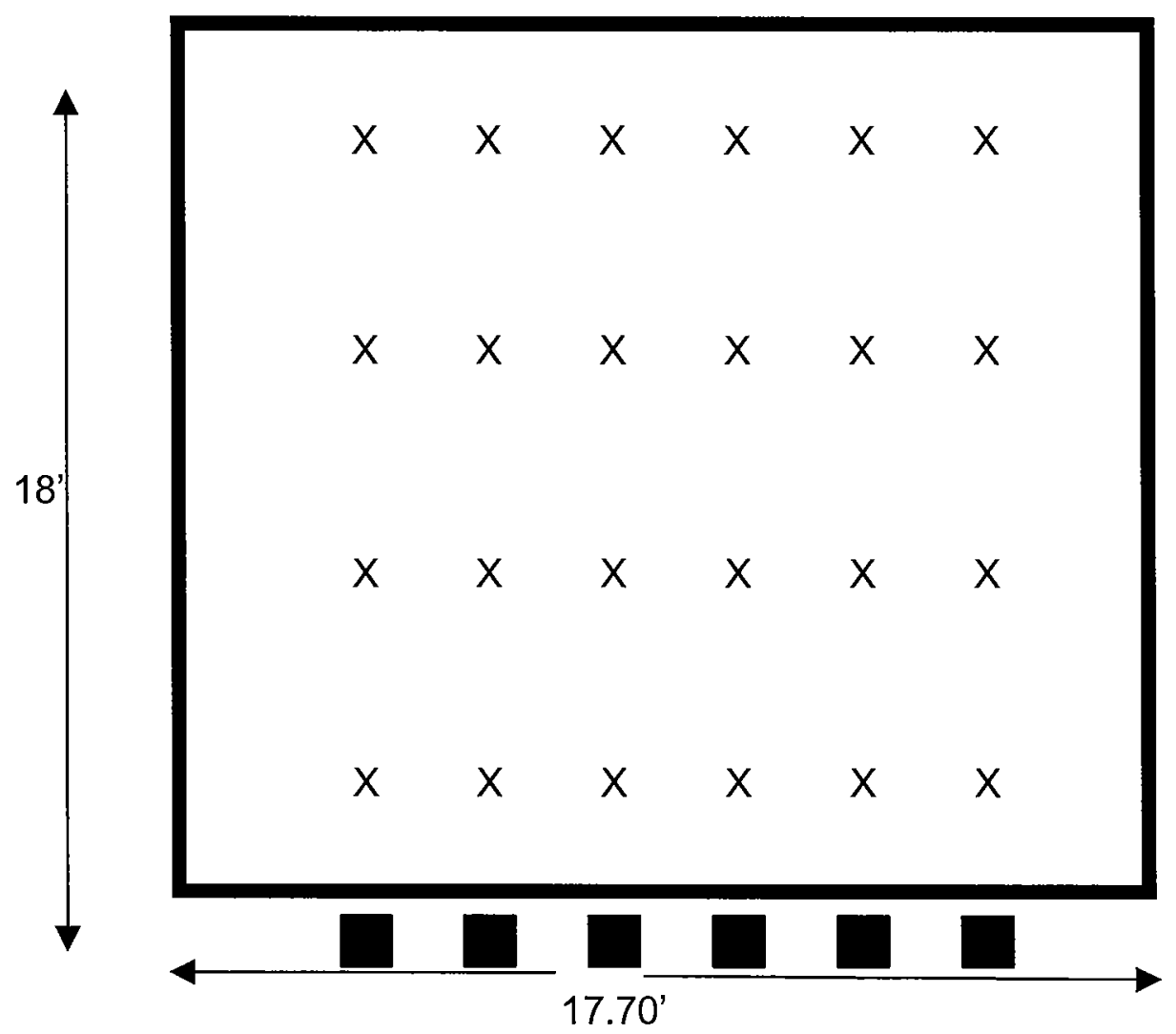

Job: We Energies

Marquette, Michigan

Date: February 14 through 16, 2006

Area: 318.600 Square Feet

Test Location: Baghouse Outlet

No. Test Ports: 6

Length: 18.0 Feet

Tests Points per Port: 4

Width: 17.70 Feet 


\begin{tabular}{|c|c|c|c|c|c|c|c|c|c|}
\hline ADA ID & Field ID & Project & Unit & Date & Type & Location & Comments & $\%$ LOI & $\begin{array}{c}\mathrm{Hg} \\
(\mathrm{ng} / \mathrm{g})\end{array}$ \\
\hline 4794 & PIPP37 & $7005-74$ & 7 & 2/14/06 0:00 & Fly Ash & ESP-7A & Base line testing & 0.66 & $<10$ \\
\hline 4795 & PIPP38 & $7005-74$ & 7 & 2/14/06 0:00 & Fly Ash & ESP-7B & Base line testing & 0.61 & $<10$ \\
\hline 4796 & PIPP39 & $7005-74$ & 7 & 2/14/06 0:00 & Fly Ash & ESP-7C & Base line testing & 0.64 & $<10$ \\
\hline 4797 & PIPP40 & $7005-74$ & 7 & 2/14/06 0:00 & Fly Ash & ESP-7D & Base line testing & 0.7 & $<10$ \\
\hline 4798 & PIPP41 & $7005-74$ & 7 & 2/14/06 0:00 & Fly Ash & ESP-7E & Base line testing & 0.73 & $<10$ \\
\hline 4799 & PIPP42 & $7005-74$ & 7 & 2/14/06 0:00 & Fly Ash & ESP-7F & Base line testing & 0.67 & $<10$ \\
\hline 4800 & PIPP43 & $7005-74$ & 7 & 2/14/06 0:00 & Fly Ash & ESP-7G & Base line testing & 0.72 & $<10$ \\
\hline 4801 & PIPP44 & $7005-74$ & 7 & 2/14/06 0:00 & Fly Ash & ESP-7H & Base line testing & 0.63 & $<10$ \\
\hline 4802 & PIPP45 & $7005-74$ & 7 & 2/14/06 0:00 & Fly Ash & ESP-7I & Base line testing & 0.71 & $<10$ \\
\hline 4803 & PIPP46 & $7005-74$ & 7 & 2/14/06 0:00 & Fly Ash & ESP-7J & Base line testing & 0.73 & $<10$ \\
\hline 4804 & PIPP47 & $7005-74$ & 7 & 2/14/06 0:00 & Fly Ash & ESP-7K & Base line testing & 0.74 & $<10$ \\
\hline 4805 & PIPP48 & $7005-74$ & 7 & 2/14/06 0:00 & Fly Ash & ESP-7L & Base line testing & 0.85 & $<10$ \\
\hline 4806 & PIPP49 & $7005-74$ & 8 & 2/15/06 0:00 & Fly Ash & ESP-8A & Base line testing & 1.15 & $<10$ \\
\hline 4807 & PIPP50 & $7005-74$ & 8 & 2/15/06 0:00 & Fly Ash & ESP-8B & Base line testing & 0.99 & $<10$ \\
\hline 4808 & PIPP51 & $7005-74$ & 8 & 2/15/06 0:00 & Fly Ash & ESP-8C & Base line testing & 0.67 & $<10$ \\
\hline 4809 & PIPP52 & $7005-74$ & 8 & 2/15/06 0:00 & Fly Ash & ESP-8D & Base line testing & 0.8 & $<10$ \\
\hline 4810 & PIPP53 & $7005-74$ & 8 & 2/15/06 0:00 & Fly Ash & ESP-8E & Base line testing & 0.86 & $<10$ \\
\hline 4811 & PIPP54 & $7005-74$ & 8 & 2/15/06 0:00 & Fly Ash & ESP-8F & Base line testing & 0.82 & $<10$ \\
\hline 4812 & PIPP55 & $7005-74$ & 8 & 2/15/06 0:00 & Fly Ash & ESP-8G & Base line testing & 0.71 & $<10$ \\
\hline 4813 & PIPP56 & $7005-74$ & 8 & 2/15/06 0:00 & Fly Ash & ESP-8H & Base line testing & 0.68 & $<10$ \\
\hline 4814 & PIPP57 & $7005-74$ & 8 & 2/15/06 0:00 & Fly Ash & ESP-8I & Base line testing & 0.84 & $<10$ \\
\hline 4815 & PIPP58 & $7005-74$ & 8 & 2/15/06 0:00 & Fly Ash & ESP-8J & Base line testing & 0.8 & $<10$ \\
\hline 4816 & PIPP59 & $7005-74$ & 8 & 2/15/06 0:00 & Fly Ash & ESP-8K & Base line testing & 0.79 & $<10$ \\
\hline 4817 & PIPP60 & $7005-74$ & 8 & 2/15/06 0:00 & Fly Ash & ESP-8L & Base line testing & 0.74 & $<10$ \\
\hline 4818 & PIPP61 & $7005-74$ & 9 & 2/16/06 0:00 & Fly Ash & ESP-9A & Base line testing & 1.5 & $<10$ \\
\hline 4819 & PIPP62 & $7005-74$ & 9 & 2/16/06 0:00 & Fly Ash & ESP-9B & Base line testing & 1.15 & $<10$ \\
\hline 4820 & PIPP63 & $7005-74$ & 9 & 2/16/06 0:00 & Fly Ash & ESP-9C & Base line testing & 0.65 & $<10$ \\
\hline 4821 & PIPP64 & $7005-74$ & 9 & 2/16/06 0:00 & Fly Ash & ESP-9D & Base line testing & 1.05 & $<10$ \\
\hline 4822 & PIPP65 & $7005-74$ & 9 & 2/16/06 0:00 & Fly Ash & ESP-9E & Base line testing & 1.19 & $<10$ \\
\hline 4823 & PIPP66 & $7005-74$ & 9 & 2/16/06 0:00 & Fly Ash & ESP-9F & Base line testing & 1.21 & $<10$ \\
\hline 4824 & PIPP67 & $7005-74$ & 9 & 2/16/06 0:00 & Fly Ash & ESP-9G & Base line testing & 0.83 & $<10$ \\
\hline 4825 & PIPP68 & $7005-74$ & 9 & 2/16/06 0:00 & Fly Ash & ESP-9H & Base line testing & 0.66 & $<10$ \\
\hline 4826 & PIPP69 & $7005-74$ & 9 & 2/16/06 0:00 & Fly Ash & ESP-9I & Base line testing & 0.94 & $<10$ \\
\hline 4827 & PIPP70 & $7005-74$ & 9 & 2/16/06 0:00 & Fly Ash & ESP-9J & Base line testing & 1.14 & $<10$ \\
\hline 4828 & PIPP71 & $7005-74$ & 9 & 2/16/06 0:00 & Fly Ash & ESP-9K & Base line testing & 0.77 & $<10$ \\
\hline 4829 & PIPP72 & $7005-74$ & 9 & 2/16/06 0:00 & Fly Ash & ESP-9L & Base line testing & 0.74 & $<10$ \\
\hline 4830 & PIPP73 & $7005-74$ & & 2/14/06 0:00 & Fly Ash & $\mathrm{BH}-1$ & Base line testing & 11.04 & 4690 \\
\hline
\end{tabular}




\begin{tabular}{|c|c|c|c|c|c|c|c|c|c|}
\hline ADA ID & Field ID & Project & Unit & Date & Type & Location & Comments & $\%$ LOI & $\begin{array}{c}\mathrm{Hg} \\
\text { (ng/g) }\end{array}$ \\
\hline 4831 & PIPP74 & $7005-74$ & & 2/14/06 0:00 & Fly Ash & $\mathrm{BH}-2$ & Base line testing & 10.87 & 5590 \\
\hline 4832 & PIPP75 & $7005-74$ & & $2 / 14 / 060: 00$ & Fly Ash & $\mathrm{BH}-3$ & Base line testing & 6.62 & 3620 \\
\hline 4833 & PIPP76 & $7005-74$ & & 2/14/06 0:00 & Fly Ash & $\mathrm{BH}-4$ & Base line testing & 10.85 & 9330 \\
\hline 4834 & PIPP77 & $7005-74$ & & 2/14/06 0:00 & Fly Ash & $\mathrm{BH}-5$ & Base line testing & 6.94 & 4290 \\
\hline 4835 & PIPP78 & $7005-74$ & & $2 / 14 / 06$ 0:00 & Fly Ash & $\mathrm{BH}-6$ & Base line testing & 12.99 & 2810 \\
\hline 4836 & PIPP79 & $7005-74$ & & 2/14/06 0:00 & Fly Ash & $\mathrm{BH}-7$ & Base line testing & 11.59 & 1790 \\
\hline 4837 & PIPP80 & $7005-74$ & & $2 / 14 / 060: 00$ & Fly Ash & $\mathrm{BH}-8$ & Base line testing & 12.72 & 7830 \\
\hline 4838 & PIPP81 & $7005-74$ & & 2/14/06 0:00 & Fly Ash & $\mathrm{BH}-9$ & Base line testing & 15.33 & 14100 \\
\hline 4839 & PIPP82 & $7005-74$ & & 2/14/06 0:00 & Fly Ash & $\mathrm{BH}-10$ & Base line testing & 17.85 & 8580 \\
\hline 4840 & PIPP83 & $7005-74$ & & 2/15/06 0:00 & Fly Ash & $\mathrm{BH}-1$ & Base line testing & 11.49 & 4770 \\
\hline 4841 & PIPP84 & $7005-74$ & & 2/15/06 0:00 & Fly Ash & $\mathrm{BH}-2$ & Base line testing & 11.03 & 6010 \\
\hline 4842 & PIPP85 & $7005-74$ & & $2 / 15 / 060: 00$ & Fly Ash & $\mathrm{BH}-3$ & Base line testing & 7.05 & 3380 \\
\hline 4843 & PIPP86 & $7005-74$ & & 2/15/06 0:00 & Fly Ash & $\mathrm{BH}-4$ & Base line testing & 12.03 & 6040 \\
\hline 4844 & PIPP87 & $7005-74$ & & $2 / 15 / 060: 00$ & Fly Ash & $\mathrm{BH}-5$ & Base line testing & 8.38 & 6320 \\
\hline 4845 & PIPP88 & $7005-74$ & & $2 / 15 / 060: 00$ & Fly Ash & $\mathrm{BH}-6$ & Base line testing & 12.7 & 2420 \\
\hline 4846 & PIPP89 & $7005-74$ & & 2/15/06 0:00 & Fly Ash & $\mathrm{BH}-7$ & Base line testing & 9.64 & 1820 \\
\hline 4847 & PIPP90 & $7005-74$ & & $2 / 15 / 060: 00$ & Fly Ash & $\mathrm{BH}-8$ & Base line testing & 11.17 & 3460 \\
\hline 4848 & PIPP91 & $7005-74$ & & 2/15/06 0:00 & Fly Ash & $\mathrm{BH}-9$ & Base line testing & 15.48 & 9320 \\
\hline 4849 & PIPP92 & $7005-74$ & & 2/15/06 0:00 & Fly Ash & $\mathrm{BH}-10$ & Base line testing & 13.31 & 7550 \\
\hline 4850 & PIPP93 & $7005-74$ & & 2/16/06 0:00 & Fly Ash & $\mathrm{BH}-1$ & Base line testing & 9.7 & 2700 \\
\hline 4851 & PIPP94 & $7005-74$ & & 2/16/06 0:00 & Fly Ash & $\mathrm{BH}-2$ & Base line testing & 12.45 & 4010 \\
\hline 4852 & PIPP95 & $7005-74$ & & $2 / 16 / 060: 00$ & Fly Ash & $\mathrm{BH}-3$ & Base line testing & 16.07 & 3020 \\
\hline 4853 & PIPP96 & $7005-74$ & & $2 / 16 / 060: 00$ & Fly Ash & $\mathrm{BH}-4$ & Base line testing & 18.52 & 4780 \\
\hline 4854 & PIPP97 & $7005-74$ & & 2/16/06 0:00 & Fly Ash & $\mathrm{BH}-5$ & Base line testing & 11.5 & 5480 \\
\hline 4855 & PIPP98 & $7005-74$ & & 2/16/06 0:00 & Fly Ash & $\mathrm{BH}-6$ & Base line testing & 6.89 & 2170 \\
\hline 4856 & PIPP99 & $7005-74$ & & 2/16/06 0:00 & Fly Ash & $\mathrm{BH}-7$ & Base line testing & 6.88 & 1950 \\
\hline 4857 & PIPP100 & $7005-74$ & & $2 / 16 / 060: 00$ & Fly Ash & $\mathrm{BH}-8$ & Base line testing & 12.77 & 2530 \\
\hline 4858 & PIPP101 & $7005-74$ & & 2/16/06 0:00 & Fly Ash & $\mathrm{BH}-9$ & Base line testing & 13.39 & 3670 \\
\hline 4859 & PIPP102 & $7005-74$ & & 2/16/06 0:00 & Fly Ash & $\mathrm{BH}-10$ & Base line testing & 11.57 & 1920 \\
\hline
\end{tabular}




\begin{tabular}{|c|c|c|c|c|c|c|c|c|}
\hline ADA ID & Field ID & Project & Unit & Date & Type & Location & Comments & $\begin{array}{c}\mathrm{Hg} \\
\text { (ng/g dry) }\end{array}$ \\
\hline 4758 & PIPP1 & $7005-74$ & 7 & 2/14/06 0:00 & Coal & UNIT 7 - A1 & $\begin{array}{c}\text { Base line testing - } \\
\text { uncrushed coal }\end{array}$ & 69 \\
\hline 4759 & PIPP2 & $7005-74$ & 7 & 2/14/06 0:00 & Coal & UNIT 7 - A2 & $\begin{array}{c}\text { Base line testing - } \\
\text { uncrushed coal }\end{array}$ & 87.4 \\
\hline 4760 & PIPP3 & $7005-74$ & 7 & 2/14/06 0:00 & Coal & UNIT 7 - B1 & $\begin{array}{l}\text { Base line testing - } \\
\text { uncrushed coal }\end{array}$ & 52.2 \\
\hline 4761 & PIPP4 & $7005-74$ & 7 & 2/14/06 0:00 & Coal & UNIT 7 - B2 & $\begin{array}{c}\text { Base line testing - } \\
\text { uncrushed coal }\end{array}$ & 80.7 \\
\hline 4762 & PIPP5 & $7005-74$ & 8 & 2/14/06 0:00 & Coal & UNIT 8 - A1 & $\begin{array}{c}\text { Base line testing - } \\
\text { uncrushed coal }\end{array}$ & 58.6 \\
\hline 4763 & PIPP6 & $7005-74$ & 8 & 2/14/06 0:00 & Coal & UNIT 8 - A2 & $\begin{array}{l}\text { Base line testing - } \\
\text { uncrushed coal }\end{array}$ & 48.4 \\
\hline 4764 & PIPP7 & $7005-74$ & 8 & 2/14/06 0:00 & Coal & UNIT 8 - B1 & $\begin{array}{c}\text { Base line testing - } \\
\text { uncrushed coal }\end{array}$ & 53 \\
\hline 4765 & PIPP8 & $7005-74$ & 8 & 2/14/06 0:00 & Coal & UNIT 8 - B2 & $\begin{array}{c}\text { Base line testing - } \\
\text { uncrushed coal }\end{array}$ & 55.9 \\
\hline 4766 & PIPP9 & $7005-74$ & 9 & 2/14/06 0:00 & Coal & UNIT 9 - A1 & $\begin{array}{l}\text { Base line testing - } \\
\text { uncrushed coal }\end{array}$ & 61.8 \\
\hline 4767 & PIPP10 & $7005-74$ & 9 & 2/14/06 0:00 & Coal & UNIT 9 - A2 & $\begin{array}{c}\text { Base line testing - } \\
\text { uncrushed coal }\end{array}$ & 60.9 \\
\hline 4768 & PIPP11 & $7005-74$ & 9 & 2/14/06 0:00 & Coal & UNIT 9 - B1 & $\begin{array}{c}\text { Base line testing - } \\
\text { uncrushed coal }\end{array}$ & 53.4 \\
\hline 4769 & PIPP12 & $7005-74$ & 9 & 2/14/06 0:00 & Coal & UNIT 9 - B2 & $\begin{array}{c}\text { Base line testing - } \\
\text { uncrushed coal }\end{array}$ & 52.5 \\
\hline 4770 & PIPP13 & $7005-74$ & 7 & 2/15/06 0:00 & Coal & UNIT 7 - A1 & $\begin{array}{l}\text { Base line testing - } \\
\text { uncrushed coal }\end{array}$ & 53.5 \\
\hline 4771 & PIPP14 & $7005-74$ & 7 & 2/15/06 0:00 & Coal & UNIT 7 - A2 & $\begin{array}{c}\text { Base line testing - } \\
\text { uncrushed coal }\end{array}$ & 73.2 \\
\hline 4772 & PIPP15 & $7005-74$ & 7 & 2/15/06 0:00 & Coal & UNIT 7 - B1 & $\begin{array}{l}\text { Base line testing - } \\
\text { uncrushed coal }\end{array}$ & 48.9 \\
\hline 4773 & PIPP16 & $7005-74$ & 7 & 2/15/06 0:00 & Coal & UNIT 7 - B2 & $\begin{array}{c}\text { Base line testing - } \\
\text { uncrushed coal }\end{array}$ & 46.9 \\
\hline 4774 & PIPP17 & $7005-74$ & 8 & 2/15/06 0:00 & Coal & UNIT 8 - A1 & $\begin{array}{l}\text { Base line testing - } \\
\text { uncrushed coal }\end{array}$ & 47.6 \\
\hline 4775 & PIPP18 & $7005-74$ & 8 & 2/15/06 0:00 & Coal & UNIT 8 - A2 & $\begin{array}{l}\text { Base line testing - } \\
\text { uncrushed coal }\end{array}$ & 53.6 \\
\hline 4776 & PIPP19 & $7005-74$ & 8 & 2/15/06 0:00 & Coal & UNIT 8 - B1 & $\begin{array}{l}\text { Base line testing - } \\
\text { uncrushed coal }\end{array}$ & 89.3 \\
\hline 4777 & PIPP20 & $7005-74$ & 8 & 2/15/06 0:00 & Coal & UNIT 8 - B2 & $\begin{array}{c}\text { Base line testing - } \\
\text { uncrushed coal }\end{array}$ & 59.6 \\
\hline 4778 & PIPP21 & $7005-74$ & 9 & 2/15/06 0:00 & Coal & UNIT 9 - A1 & $\begin{array}{l}\text { Base line testing - } \\
\text { uncrushed coal }\end{array}$ & 55.7 \\
\hline 4779 & PIPP22 & $7005-74$ & 9 & 2/15/06 0:00 & Coal & UNIT 9 - A2 & $\begin{array}{c}\text { Base line testing - } \\
\text { uncrushed coal }\end{array}$ & 54.4 \\
\hline 4780 & PIPP23 & $7005-74$ & 9 & 2/15/06 0:00 & Coal & UNIT 9 - B1 & $\begin{array}{l}\text { Base line testing - } \\
\text { uncrushed coal }\end{array}$ & 57.2 \\
\hline 4781 & PIPP24 & $7005-74$ & 9 & 2/15/06 0:00 & Coal & UNIT 9 - B2 & $\begin{array}{l}\text { Base line testing - } \\
\text { uncrushed coal }\end{array}$ & 60.5 \\
\hline 4782 & PIPP25 & $7005-74$ & 7 & 2/16/06 0:00 & Coal & UNIT 7 - A1 & $\begin{array}{l}\text { Base line testing - } \\
\text { uncrushed coal }\end{array}$ & 56.6 \\
\hline 4783 & PIPP26 & $7005-74$ & 7 & 2/16/06 0:00 & Coal & UNIT 7 - A2 & $\begin{array}{c}\text { Base line testing - } \\
\text { uncrushed coal }\end{array}$ & 35.1 \\
\hline 4784 & PIPP27 & $7005-74$ & 7 & 2/16/06 0:00 & Coal & UNIT 7 - B1 & $\begin{array}{l}\text { Base line testing - } \\
\text { uncrushed coal }\end{array}$ & 58.2 \\
\hline 4785 & PIPP28 & $7005-74$ & 7 & 2/16/06 0:00 & Coal & UNIT 7 - B2 & $\begin{array}{c}\text { Base line testing - } \\
\text { uncrushed coal }\end{array}$ & 44.9 \\
\hline 4786 & PIPP29 & $7005-74$ & 8 & 2/16/06 0:00 & Coal & UNIT 8 - A1 & $\begin{array}{c}\text { Base line testing - } \\
\text { uncrushed coal }\end{array}$ & 60.8 \\
\hline 4787 & PIPP30 & $7005-74$ & 8 & 2/16/06 0:00 & Coal & UNIT 8 - A2 & $\begin{array}{l}\text { Base line testing - } \\
\text { uncrushed coal }\end{array}$ & 63.9 \\
\hline 4788 & PIPP31 & $7005-74$ & 8 & 2/16/06 0:00 & Coal & UNIT 8 - B1 & $\begin{array}{l}\text { Base line testing - } \\
\text { uncrushed coal }\end{array}$ & 51.4 \\
\hline 4789 & PIPP32 & $7005-74$ & 8 & 2/16/06 0:00 & Coal & UNIT 8 - B2 & $\begin{array}{c}\text { Base line testing - } \\
\text { uncrushed coal }\end{array}$ & 62.1 \\
\hline 4790 & PIPP33 & $7005-74$ & 9 & 2/16/06 0:00 & Coal & UNIT 9 - A1 & $\begin{array}{c}\text { Base line testing - } \\
\text { uncrushed coal }\end{array}$ & 51.1 \\
\hline
\end{tabular}


Mercury

\begin{tabular}{|c|c|c|c|c|c|c|c|c|}
\hline ADA ID & Field ID & Project & Unit & Date & Type & Location & Comments & $\begin{array}{c}\mathrm{Hg} \\
\text { (ng/g dry) }\end{array}$ \\
\hline 4791 & PIPP34 & $7005-74$ & 9 & 2/16/06 0:00 & Coal & UNIT 9 - A2 & $\begin{array}{l}\text { Base line testing - } \\
\text { uncrushed coal }\end{array}$ & 58.9 \\
\hline 4792 & PIPP35 & $7005-74$ & 9 & 2/16/06 0:00 & Coal & UNIT 9 - B1 & $\begin{array}{c}\text { Base line testing - } \\
\text { uncrushed coal }\end{array}$ & 43.6 \\
\hline 4793 & PIPP36 & $7005-74$ & 9 & 2/16/06 0:00 & Coal & UNIT 9 - B2 & $\begin{array}{c}\text { Base line testing - } \\
\text { uncrushed coal }\end{array}$ & 47.9 \\
\hline 4894 & 4759DUP & $7005-74$ & 7 & 2/14/06 0:00 & Coal & UNIT 7 - A2 & Duplicate of 4759 & 60.4 \\
\hline 4895 & 4776DUP & $7005-74$ & 8 & 2/15/06 0:00 & Coal & UNIT 8 - B1 & Duplicate of 4776 & 41.3 \\
\hline 4896 & 4790DUP & $7005-74$ & 9 & 2/16/06 0:00 & Coal & UNIT 9 - A1 & Duplicate of 4790 & 36 \\
\hline
\end{tabular}




\begin{tabular}{|c|c|c|c|c|c|c|c|c|}
\hline ADA ID & Field ID & Project & Unit & Date & Type & Location & Comments & $\begin{array}{c}\mathrm{Cl} \\
\text { (ug/g) }\end{array}$ \\
\hline 4758 & PIPP1 & $7005-74$ & 7 & 2/14/06 0:00 & Coal & UNIT 7 - A1 & $\begin{array}{c}\text { Base line testing - } \\
\text { uncrushed coal }\end{array}$ & 46.72 \\
\hline 4759 & PIPP2 & $7005-74$ & 7 & 2/14/06 0:00 & Coal & UNIT 7 - A2 & $\begin{array}{c}\text { Base line testing - } \\
\text { uncrushed coal }\end{array}$ & 68.64 \\
\hline 4760 & PIPP3 & $7005-74$ & 7 & 2/14/06 0:00 & Coal & UNIT 7 - B1 & $\begin{array}{l}\text { Base line testing - } \\
\text { uncrushed coal }\end{array}$ & 70.39 \\
\hline 4761 & PIPP4 & $7005-74$ & 7 & 2/14/06 0:00 & Coal & UNIT 7 - B2 & $\begin{array}{c}\text { Base line testing - } \\
\text { uncrushed coal }\end{array}$ & 82.86 \\
\hline 4762 & PIPP5 & $7005-74$ & 8 & 2/14/06 0:00 & Coal & UNIT 8 - A1 & $\begin{array}{c}\text { Base line testing - } \\
\text { uncrushed coal }\end{array}$ & 115.96 \\
\hline 4763 & PIPP6 & $7005-74$ & 8 & 2/14/06 0:00 & Coal & UNIT 8 - A2 & $\begin{array}{l}\text { Base line testing - } \\
\text { uncrushed coal }\end{array}$ & 104.47 \\
\hline 4764 & PIPP7 & $7005-74$ & 8 & 2/14/06 0:00 & Coal & UNIT 8 - B1 & $\begin{array}{c}\text { Base line testing - } \\
\text { uncrushed coal }\end{array}$ & 68.58 \\
\hline 4765 & PIPP8 & $7005-74$ & 8 & 2/14/06 0:00 & Coal & UNIT 8 - B2 & $\begin{array}{c}\text { Base line testing - } \\
\text { uncrushed coal }\end{array}$ & 113.48 \\
\hline 4766 & PIPP9 & $7005-74$ & 9 & 2/14/06 0:00 & Coal & UNIT 9 - A1 & $\begin{array}{l}\text { Base line testing - } \\
\text { uncrushed coal }\end{array}$ & 69.69 \\
\hline 4767 & PIPP10 & $7005-74$ & 9 & 2/14/06 0:00 & Coal & UNIT 9 - A2 & $\begin{array}{c}\text { Base line testing - } \\
\text { uncrushed coal }\end{array}$ & 91.31 \\
\hline 4768 & PIPP11 & $7005-74$ & 9 & 2/14/06 0:00 & Coal & UNIT 9 - B1 & $\begin{array}{c}\text { Base line testing - } \\
\text { uncrushed coal }\end{array}$ & 63.86 \\
\hline 4769 & PIPP12 & $7005-74$ & 9 & 2/14/06 0:00 & Coal & UNIT 9 - B2 & $\begin{array}{c}\text { Base line testing - } \\
\text { uncrushed coal }\end{array}$ & 64.35 \\
\hline 4770 & PIPP13 & $7005-74$ & 7 & 2/15/06 0:00 & Coal & UNIT 7 - A1 & $\begin{array}{l}\text { Base line testing - } \\
\text { uncrushed coal }\end{array}$ & 49 \\
\hline 4771 & PIPP14 & $7005-74$ & 7 & 2/15/06 0:00 & Coal & UNIT 7 - A2 & $\begin{array}{c}\text { Base line testing - } \\
\text { uncrushed coal }\end{array}$ & 53.99 \\
\hline 4772 & PIPP15 & $7005-74$ & 7 & 2/15/06 0:00 & Coal & UNIT 7 - B1 & $\begin{array}{l}\text { Base line testing - } \\
\text { uncrushed coal }\end{array}$ & 61.62 \\
\hline 4773 & PIPP16 & $7005-74$ & 7 & 2/15/06 0:00 & Coal & UNIT 7 - B2 & $\begin{array}{c}\text { Base line testing - } \\
\text { uncrushed coal }\end{array}$ & 77.72 \\
\hline 4774 & PIPP17 & $7005-74$ & 8 & 2/15/06 0:00 & Coal & UNIT 8 - A1 & $\begin{array}{l}\text { Base line testing - } \\
\text { uncrushed coal }\end{array}$ & 76.67 \\
\hline 4775 & PIPP18 & $7005-74$ & 8 & 2/15/06 0:00 & Coal & UNIT 8 - A2 & $\begin{array}{l}\text { Base line testing - } \\
\text { uncrushed coal }\end{array}$ & 81.46 \\
\hline 4776 & PIPP19 & $7005-74$ & 8 & 2/15/06 0:00 & Coal & UNIT 8 - B1 & $\begin{array}{l}\text { Base line testing - } \\
\text { uncrushed coal }\end{array}$ & 66.24 \\
\hline 4777 & PIPP20 & $7005-74$ & 8 & 2/15/06 0:00 & Coal & UNIT 8 - B2 & $\begin{array}{c}\text { Base line testing - } \\
\text { uncrushed coal }\end{array}$ & 100.73 \\
\hline 4778 & PIPP21 & $7005-74$ & 9 & 2/15/06 0:00 & Coal & UNIT 9 - A1 & $\begin{array}{l}\text { Base line testing - } \\
\text { uncrushed coal }\end{array}$ & 85.1 \\
\hline 4779 & PIPP22 & $7005-74$ & 9 & 2/15/06 0:00 & Coal & UNIT 9 - A2 & $\begin{array}{c}\text { Base line testing - } \\
\text { uncrushed coal }\end{array}$ & 60.01 \\
\hline 4780 & PIPP23 & $7005-74$ & 9 & 2/15/06 0:00 & Coal & UNIT 9 - B1 & $\begin{array}{l}\text { Base line testing - } \\
\text { uncrushed coal }\end{array}$ & 73.14 \\
\hline 4781 & PIPP24 & $7005-74$ & 9 & 2/15/06 0:00 & Coal & UNIT 9 - B2 & $\begin{array}{l}\text { Base line testing - } \\
\text { uncrushed coal }\end{array}$ & 54.39 \\
\hline 4782 & PIPP25 & $7005-74$ & 7 & 2/16/06 0:00 & Coal & UNIT 7 - A1 & $\begin{array}{l}\text { Base line testing - } \\
\text { uncrushed coal }\end{array}$ & 49.38 \\
\hline 4783 & PIPP26 & $7005-74$ & 7 & 2/16/06 0:00 & Coal & UNIT 7 - A2 & $\begin{array}{c}\text { Base line testing - } \\
\text { uncrushed coal }\end{array}$ & 48.58 \\
\hline 4784 & PIPP27 & $7005-74$ & 7 & 2/16/06 0:00 & Coal & UNIT 7 - B1 & $\begin{array}{l}\text { Base line testing - } \\
\text { uncrushed coal }\end{array}$ & 74.89 \\
\hline 4785 & PIPP28 & $7005-74$ & 7 & 2/16/06 0:00 & Coal & UNIT 7 - B2 & $\begin{array}{c}\text { Base line testing - } \\
\text { uncrushed coal }\end{array}$ & 43.13 \\
\hline 4786 & PIPP29 & $7005-74$ & 8 & 2/16/06 0:00 & Coal & UNIT 8 - A1 & $\begin{array}{c}\text { Base line testing - } \\
\text { uncrushed coal }\end{array}$ & 74.67 \\
\hline 4787 & PIPP30 & $7005-74$ & 8 & 2/16/06 0:00 & Coal & UNIT 8 - A2 & $\begin{array}{l}\text { Base line testing - } \\
\text { uncrushed coal }\end{array}$ & 65.39 \\
\hline 4788 & PIPP31 & $7005-74$ & 8 & 2/16/06 0:00 & Coal & UNIT 8 - B1 & $\begin{array}{l}\text { Base line testing - } \\
\text { uncrushed coal }\end{array}$ & 64.24 \\
\hline 4789 & PIPP32 & $7005-74$ & 8 & 2/16/06 0:00 & Coal & UNIT 8 - B2 & $\begin{array}{c}\text { Base line testing - } \\
\text { uncrushed coal }\end{array}$ & 81.06 \\
\hline 4790 & PIPP33 & $7005-74$ & 9 & 2/16/06 0:00 & Coal & UNIT 9 - A1 & $\begin{array}{c}\text { Base line testing - } \\
\text { uncrushed coal }\end{array}$ & 80.06 \\
\hline
\end{tabular}




\begin{tabular}{|c|c|c|c|c|c|c|c|c|}
\hline ADA ID & Field ID & Project & Unit & Date & Type & Location & Comments & $\begin{array}{c}\mathrm{Cl} \\
(\mathrm{ug} / \mathrm{g})\end{array}$ \\
\hline 4791 & PIPP34 & $7005-74$ & 9 & 2/16/06 0:00 & Coal & UNIT 9 - A2 & $\begin{array}{c}\text { Base line testing - } \\
\text { uncrushed coal }\end{array}$ & 56.21 \\
\hline 4792 & PIPP35 & $7005-74$ & 9 & 2/16/06 0:00 & Coal & UNIT 9 - B1 & $\begin{array}{l}\text { Base line testing - } \\
\text { uncrushed coal }\end{array}$ & 75.49 \\
\hline 4793 & PIPP36 & $7005-74$ & 9 & 2/16/06 0:00 & Coal & UNIT 9 - B2 & $\begin{array}{c}\text { Base line testing - } \\
\text { uncrushed coal }\end{array}$ & 78.19 \\
\hline 4894 & 4759DUP & $7005-74$ & 7 & 2/14/06 0:00 & Coal & UNIT 7 - A2 & Duplicate of 4759 & 68.12 \\
\hline 4895 & 4776DUP & $7005-74$ & 8 & 2/15/06 0:00 & Coal & UNIT 8 - B1 & Duplicate of 4776 & 47.24 \\
\hline 4896 & 4790DUP & $7005-74$ & 9 & 2/16/06 0:00 & Coal & UNIT 9 - A1 & Duplicate of 4790 & 82.79 \\
\hline
\end{tabular}




\begin{tabular}{|c|c|c|c|c|c|c|c|c|c|c|c|c|c|c|c|c|c|c|c|c|}
\hline & Field ID & Project & Unit & Date & Type & Location & Eommen & $\begin{array}{l}\text { \% Ash } \\
\text { (as rec) }\end{array}$ & $\begin{array}{l}\% \text { Ash } \\
\text { (dry)) }\end{array}$ & $\begin{array}{c}\% \mathrm{C} \\
\text { (as rec) }\end{array}$ & 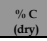 & $\begin{array}{c}\%=\mathrm{H} \\
\text { (as rece) } \\
\text { (a) }\end{array}$ & 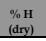 & $\begin{array}{l}\% \% \mathrm{H} 2 \mathrm{O} \\
\text { (as rec) }\end{array}$ & $\begin{array}{l}\% \mathrm{~N} \\
\text { (as rec) }\end{array}$ & $\begin{array}{l}\begin{array}{l}\% \mathrm{~N} \\
(\mathrm{dryy})\end{array} \\
\end{array}$ & $\begin{array}{c}\% 0 \\
\text { (as rec) } \\
\text { (at }\end{array}$ & $\begin{array}{l}\% 0 \\
\text { (dry) } \\
\text { (d) }\end{array}$ & 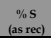 & 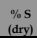 \\
\hline 4758 & \begin{tabular}{|l|} 
PIPP1 \\
\end{tabular} & \begin{tabular}{|l|l|}
$7005-74$ & \\
\end{tabular} & 7 & 2/141060 0:00 & Coal & UNIT 7-A1 & $\begin{array}{l}\text { Basal inin testing- } \\
\text { uncushhed coal }\end{array}$ & 4.29 & 5.84 & 52.67 & 71.72 & 3.64 & 4.96 & 26.56 & 0.68 & 0.92 & 11.90 & 16.21 & 0.26 & 0.35 \\
\hline 4759 & \begin{tabular}{|l|} 
PIPP2 \\
\end{tabular} & \begin{tabular}{|l|l|}
$7005-74$ \\
\end{tabular} & 7 & 2/14/06 0:00 & Coal & UNIT 7-A2 & $\begin{array}{l}\text { Base line testing- } \\
\text { unncrushed coala }\end{array}$ & 4.16 & 5.68 & 52.57 & 71.74 & 3.66 & 5.00 & 26.72 & 0.70 & 0.95 & 11.90 & 16.23 & 0.29 & 0.40 \\
\hline 4760 & \begin{tabular}{|l|} 
PIPP3 \\
\end{tabular} & \begin{tabular}{|l|l|}
$7005-74$ & \\
\end{tabular} & 7 & 2/144/06 0:00 & Coal & UNIT 7 - B1 & $\begin{array}{l}\text { Base line testing - - } \\
\text { uncrushed coal }\end{array}$ & 4.61 & 6.26 & 52.36 & 71.14 & 3.59 & 4.88 & 26.40 & 0.68 & 0.93 & 12.10 & 16.44 & 0.26 & 0.35 \\
\hline 4761 & \begin{tabular}{|l|} 
PIPP4 \\
\end{tabular} & \begin{tabular}{|l|l|}
$7005-74$ & \\
\end{tabular} & 7 & 2/14/106 0:00 & Coal & UNIT 7 - B2 & $\begin{array}{l}\text { Base ine tetsting- } \\
\text { uncrushed coal }\end{array}$ & 4.86 & 6.66 & 51.77 & 70.97 & 3.55 & 4.86 & 27.05 & 0.69 & 0.94 & 11.80 & 16.18 & 0.28 & 0.39 \\
\hline 4762 & \begin{tabular}{|l|l|} 
PIPP5 \\
\end{tabular} & \begin{tabular}{|l|l|}
$7005-74$ & \\
\end{tabular} & 8 & 2/141/106 0:00 & Coal & UNIT 8-A1 & $\begin{array}{l}\text { Bases line testing- - } \\
\text { uncrushed coal }\end{array}$ & 4.62 & 6.29 & 52.68 & 71.66 & 3.65 & 4.97 & 26.48 & 0.70 & 0.95 & 11.59 & 15.75 & 0.28 & 0.38 \\
\hline 4763 & \begin{tabular}{|l|} 
PIPP6 \\
\end{tabular} & \begin{tabular}{|l|l|}
$7005-74$ & \\
\end{tabular} & 8 & 2/14/106 0:00 & Coal & UNIT \&-A2 & $\begin{array}{l}\text { Base line tessing - } \\
\text { uncrushed coal }\end{array}$ & 4.44 & 6.04 & 52.39 & 71.34 & 3.64 & 4.95 & 26.56 & 0.69 & 0.94 & 12.02 & 16.38 & 0.26 & 0.35 \\
\hline 4764 & \begin{tabular}{|l|} 
PIPP7 \\
\end{tabular} & \begin{tabular}{|l|l|}
$7005-74$ & \\
\end{tabular} & 8 & 2/14/106 0:00 & Coal & UNIT \& - B1 & $\begin{array}{l}\text { Basel line testing- - } \\
\text { uncrushed coal }\end{array}$ & 4.68 & 6.42 & 51.58 & 70.77 & 3.58 & 4.91 & 27.12 & 0.67 & 0.92 & 12.11 & 16.62 & 0.26 & 0.36 \\
\hline 4765 & \begin{tabular}{|l|} 
PIPP88 \\
\end{tabular} & \begin{tabular}{|l|l|}
$7005-74$ & \\
\end{tabular} & 8 & 2/141/06 0:00 & Coal & UNIT 8 - B2 & $\begin{array}{l}\text { Basel line testing - } \\
\text { uncrushed coal }\end{array}$ & 4.62 & 6.28 & 51.96 & 70.58 & 3.60 & 4.89 & 26.38 & 0.68 & 0.92 & 12.49 & 16.97 & 0.27 & 0.36 \\
\hline 4766 & \begin{tabular}{|l|} 
PIPP9 \\
\end{tabular} & \begin{tabular}{|l|l|}
$7005-74$ & \\
\end{tabular} & 9 & 2/14/106 0:00 & Coal & UNIT 9-A1 & $\begin{array}{l}\text { Basel line testing- - } \\
\text { uncrushed coal }\end{array}$ & 4.69 & 6.36 & 52.28 & 70.94 & 3.64 & 4.94 & 26.31 & 0.69 & 0.94 & 12.13 & 16.47 & 0.26 & 0.35 \\
\hline 4767 & \begin{tabular}{|l|l|} 
PIPP10 \\
\end{tabular} & \begin{tabular}{|l|l|}
$7005-74$ & \\
\end{tabular} & 9 & 2/141/06 0:00 & Coal & UNIT 9-A2 & $\begin{array}{l}\text { Basel line testing - } \\
\text { uncrushed coal }\end{array}$ & 5.16 & 6.94 & 52.30 & 70.29 & 3.62 & 4.86 & 25.59 & 0.70 & 0.94 & 12.34 & 16.58 & 0.29 & 0.39 \\
\hline 4768 & \begin{tabular}{|l|} 
PIPP11 \\
\end{tabular} & \begin{tabular}{|l|l|}
$7005-74$ & \\
\end{tabular} & 9 & 2/14/106 0:00 & Coal & UNIT 9 - B1 & $\begin{array}{l}\text { Basel line testing- - } \\
\text { uncrushed coal }\end{array}$ & 4.44 & 6.07 & 52.01 & 71.03 & 3.67 & 5.01 & 26.78 & 0.69 & 0.94 & 12.15 & 16.59 & 0.26 & 0.36 \\
\hline 4769 & \begin{tabular}{|l|l|} 
PIPP12 \\
\end{tabular} & \begin{tabular}{|l|l|}
$7005-74$ & \\
\end{tabular} & 9 & 2/14/:06 0:00 & Coal & UNIT 9 - B2 & $\begin{array}{l}\text { Basel line testing- - } \\
\text { uncrushed coal }\end{array}$ & 4.41 & 6.04 & 51.73 & 70.78 & 3.62 & 4.95 & 26.91 & 0.69 & 0.94 & 12.38 & 16.94 & 0.26 & 0.35 \\
\hline 4770 & \begin{tabular}{|l|l|}
$\mathrm{PIPP} 13$ \\
\end{tabular} & \begin{tabular}{|l|l|}
$7005-74$ & \\
\end{tabular} & 7 & 2/115/06 0:00 & Coal & UNIT 7 - A1 & $\begin{array}{l}\text { Basel line tessing - } \\
\text { uncrushed coal }\end{array}$ & 4.57 & 6.23 & 52.12 & 71.09 & 3.64 & 4.96 & 26.68 & 0.70 & 0.95 & 12.03 & 16.41 & 0.26 & 0.36 \\
\hline 4771 & \begin{tabular}{|l|l|} 
PIPP14 \\
\end{tabular} & \begin{tabular}{|l|l|}
$7005-74$ & \\
\end{tabular} & 7 & 2/151060:00 & Coal & UNIT 7 - A2 & $\begin{array}{l}\text { Base line tessing - } \\
\text { uncrushed coal }\end{array}$ & 4.23 & 5.75 & 52.52 & 71.38 & 3.72 & 5.05 & 26.42 & 0.69 & 0.94 & 12.15 & 16.51 & 0.27 & 0.37 \\
\hline 4772 & PIPP15 & \begin{tabular}{|l|l|}
$7005-74$ & \\
\end{tabular} & 7 & 2/15/106 0:00 & Coal & UNIT 7-B1 & $\begin{array}{l}\text { netesting- } \\
\text { Shed coal }\end{array}$ & 4.45 & 6.06 & 52.38 & 71.29 & 3.65 & 4.97 & 26.52 & 0.71 & 0.96 & 12.02 & 16.35 & 0.27 & 0.37 \\
\hline 4773 & \begin{tabular}{|l|l|} 
PIPP16 \\
\end{tabular} & \begin{tabular}{|l|l|}
$7005-74$ & \\
\end{tabular} & 7 & 2/151/06 0:00 & Coal & UNIT 7 - B2 & $\begin{array}{l}\text { Base line tessing- - } \\
\text { uncrushed coal }\end{array}$ & 4.40 & 6.00 & 52.23 & 71.25 & 3.58 & 4.88 & 26.70 & 0.70 & 0.95 & 12.13 & 16.57 & 0.26 & 0.35 \\
\hline 4774 & \begin{tabular}{|l|l|} 
PIPP17 \\
\end{tabular} & \begin{tabular}{|l|l|}
$7005-74$ & \\
\end{tabular} & 8 & 2/115/06 0:00 & Coal & UNIT 8-A1 & $\begin{array}{l}\text { Bases line testing- - } \\
\text { uncrushed coal }\end{array}$ & 4.49 & 6.09 & 52.60 & 71.40 & 3.60 & 4.89 & 26.33 & 0.72 & 0.98 & 11.99 & 16.27 & 0.27 & 0.37 \\
\hline 4775 & \begin{tabular}{|l|l|} 
PIPP18 \\
\end{tabular} & \begin{tabular}{|l|l|}
$7005-74$ & \\
\end{tabular} & 8 & 2/15/06 0:00 & Coal & UNIT \& - A2 & $\begin{array}{l}\text { Base line testing- - } \\
\text { uncrushed coal }\end{array}$ & 4.81 & 6.53 & 52.18 & 70.86 & 3.57 & 4.85 & 26.36 & 0.69 & 0.94 & 12.12 & 16.46 & 0.27 & 0.36 \\
\hline 4776 & \begin{tabular}{|l|l|} 
PIPP19 \\
\end{tabular} & \begin{tabular}{|l|l|}
$7005-74$ & \\
\end{tabular} & 8 & 2/115/06 0:00 & Coal & UNIT \& - B1 & $\begin{array}{l}\text { Basel line testing- - } \\
\text { uncrushed coal }\end{array}$ & 5.10 & 6.86 & 52.77 & 70.97 & 3.64 & 4.89 & 25.64 & 0.69 & 0.93 & 11.89 & 15.99 & 0.27 & 0.36 \\
\hline 4777 & PIPP20 & \begin{tabular}{|l|l|}
$7005-74$ & \\
\end{tabular} & 8 & 2/15/06 0:00 & Coal & UNIT 8 - B2 & $\begin{array}{l}\text { Basel line testing - } \\
\text { uncrushed coal }\end{array}$ & 4.76 & 6.55 & 51.62 & 71.09 & 3.55 & 4.89 & 27.39 & 0.70 & 0.97 & 11.70 & 16.11 & 0.28 & 0.39 \\
\hline 4778 & \begin{tabular}{|l|l|} 
PIPP21 \\
\end{tabular} & \begin{tabular}{|l|l|}
$7005-74$ & \\
\end{tabular} & 9 & 2/115/06 0:00 & Coal & UNIT 9-A1 & $\begin{array}{l}\text { Basel line testing- - } \\
\text { uncrushed coal }\end{array}$ & 4.93 & 6.68 & 52.44 & 71.12 & 3.57 & 4.84 & 26.26 & 0.71 & 0.96 & 11.80 & 16.00 & 0.29 & 0.40 \\
\hline 4779 & $\begin{array}{ll}\text { PIPP22 } \\
\end{array}$ & \begin{tabular}{|l|l|}
$7005-74$ & \\
\end{tabular} & 9 & 2/151/06 0:00 & Coal & UNIT 9-A2 & $\begin{array}{l}\text { Base linin tessing - } \\
\text { uncrushed coal } \\
\text { - }\end{array}$ & 4.35 & 6.00 & 51.74 & 71.44 & 3.59 & 4.95 & 27.57 & 0.68 & 0.94 & 11.82 & 16.33 & 0.25 & 0.34 \\
\hline 4780 & PIPP23 & \begin{tabular}{|l|l|}
$7005-74$ \\
\end{tabular} & 9 & 2/15/106 0:00 & Coal & UNIT 9 - B1 & $\begin{array}{l}\text { Base line testing- - } \\
\text { uncrushed coal }\end{array}$ & 4.52 & 6.12 & 52.96 & 71.70 & 3.62 & 4.90 & 26.13 & 0.72 & 0.97 & 11.77 & 15.93 & 0.28 & 0.38 \\
\hline 4781 & \begin{tabular}{|l|l|} 
PIPP24 \\
\end{tabular} & \begin{tabular}{|l|l|}
$7005-74$ \\
\end{tabular} & 9 & 2/151060:00 & Coal & UNIT 9 - B2 & $\begin{array}{l}\text { Base line tessing - } \\
\text { uncrushed coal }\end{array}$ & 4.40 & 6.06 & 51.64 & 71.06 & 3.52 & 4.84 & 27.33 & 0.69 & 0.95 & 12.16 & 16.73 & 0.26 & 0.36 \\
\hline 4782 & \begin{tabular}{|l|l|} 
PIPP25 \\
\end{tabular} & \begin{tabular}{|l|l|}
$7005-74$ & \\
\end{tabular} & 7 & 2/16/106 0:00 & Coal & UNIT 7 - A1 & $\begin{array}{l}\text { Bases line testing- - } \\
\text { uncrushed coal }\end{array}$ & 4.58 & 6.19 & 52.63 & 71.17 & 3.57 & 4.83 & 26.05 & 0.70 & 0.95 & 12.23 & 16.54 & 0.24 & 0.32 \\
\hline 4783 & \begin{tabular}{|l|l|} 
PIPP26 \\
\end{tabular} & \begin{tabular}{|l|l|}
$7005-74$ \\
\end{tabular} & 7 & 2116106 0:00 & Coal & UNIT 7 - A2 & $\begin{array}{l}\text { Bases line tessing - } \\
\text { uncrushed coal }\end{array}$ & 4.11 & 5.56 & 53.55 & 72.43 & 3.62 & 4.90 & 26.07 & 0.70 & 0.95 & 11.68 & 15.80 & 0.27 & 0.36 \\
\hline 4784 & \begin{tabular}{|l|l|} 
PIPP27 \\
\end{tabular} & \begin{tabular}{|l|l|}
$7005-74$ & \\
\end{tabular} & 7 & 2/16/106 0:00 & Coal & UNIT 7-B1 & $\begin{array}{l}\text { testing- } \\
\text { ed coal }\end{array}$ & 4.72 & 6.35 & 53.34 & 71.82 & 3.60 & 4.85 & 25.73 & 0.71 & 0.96 & 11.63 & 15.66 & 0.27 & 0.36 \\
\hline 4785 & \begin{tabular}{|l|l|} 
PIPP28 \\
\end{tabular} & \begin{tabular}{|l|l|}
$7005-74$ & \\
\end{tabular} & 7 & 2/16106 0:00 & Coal & UNIT 7- B2 & $\begin{array}{l}\text { Base line tessting- - } \\
\text { uncrushed coal }\end{array}$ & 4.16 & 5.66 & 52.90 & 72.02 & 3.47 & 4.73 & 26.55 & 0.68 & 0.93 & 11.98 & 16.31 & 0.26 & 0.35 \\
\hline 4786 & \begin{tabular}{|l|l|} 
PIPP29 \\
\end{tabular} & \begin{tabular}{|l|l|}
$7005-74$ & \\
\end{tabular} & 8 & 2/16/106 0:00 & Coal & UNIT \&-A1 & $\begin{array}{l}\text { Base } \\
\text { unc }\end{array}$ & 4.87 & 6.58 & 53.02 & 71.59 & 3.54 & 4.78 & 25.94 & 0.70 & 0.95 & 11.66 & 15.73 & 0.27 & 0.37 \\
\hline 4787 & \begin{tabular}{|l|l|} 
& \\
\end{tabular} & \begin{tabular}{|l|l|}
$7005-74$ & \\
\end{tabular} & 8 & 2/161060:00 & Coal & UNIT \& - A2 & $\begin{array}{l}\text { Bases line testing- - } \\
\text { uncrushed coal }\end{array}$ & 4.74 & 6.43 & 52.94 & 71.76 & 3.36 & 4.55 & 26.22 & 0.69 & 0.93 & 11.76 & 15.94 & 0.29 & 0.39 \\
\hline 4788 & \begin{tabular}{|l|l|} 
PIPP31 \\
\end{tabular} & \begin{tabular}{|l|l|}
$7005-74$ & \\
\end{tabular} & 8 & 2/166/106 0:00 & Coal & UNIT \&-B1 & $\begin{array}{l}\text { Base line testing- - } \\
\text { uncrushed coal }\end{array}$ & 4.54 & 6.20 & 52.64 & 71.88 & 3.64 & 4.97 & 26.77 & 0.70 & 0.95 & 11.45 & 15.64 & 0.26 & 0.36 \\
\hline 4789 & $\begin{array}{ll}\text { PIPP32 } \\
\end{array}$ & \begin{tabular}{|l|l|}
$7005-74$ & \\
\end{tabular} & 8 & 2/161/106 0:00 & Coal & UNIT 8- B2 & $\begin{array}{l}\text { Base line tessing - } \\
\text { uncrushed coal } \\
\text { - }\end{array}$ & 4.97 & 6.83 & 51.93 & 71.30 & 3.50 & 4.80 & 27.17 & 0.69 & 0.95 & 11.47 & 15.75 & 0.27 & 0.37 \\
\hline 4790 & PIPP33 & \begin{tabular}{|l|l|}
$7005-74$ \\
\end{tabular} & 9 & 2/16/106 0:00 & Coal & UNIT 9-A1 & $\begin{array}{l}\text { tedsting- } \\
\text { ed coal }\end{array}$ & 4.58 & 6.27 & 52.23 & 71.51 & 3.54 & 4.84 & 26.96 & 0.71 & 0.97 & 11.70 & 16.03 & 0.28 & 0.38 \\
\hline 4791 & PIPP34 & $\begin{array}{ll}7005-74 \\
\end{array}$ & 9 & 2/16/106 0:00 & Coal & UNIT 9 - A2 & $\begin{array}{l}\text { Base line testing- - } \\
\text { uncrushed coal }\end{array}$ & 4.94 & 6.74 & 52.33 & 71.42 & 3.51 & 4.79 & 26.73 & 0.69 & 0.94 & 11.52 & 15.73 & 0.28 & 0.38 \\
\hline 4792 & PIPP35 & \begin{tabular}{|l|l|}
$7005-74$ \\
\end{tabular} & 9 & 2/16/106 0:00 & Coal & UNIT 9 - B1 & $\begin{array}{l}\text { Base line testing- - } \\
\text { uncrushed coal }\end{array}$ & 4.35 & 5.97 & 52.67 & 72.21 & 3.52 & 4.82 & 27.06 & 0.70 & 0.96 & 11.42 & 15.65 & 0.28 & 0.39 \\
\hline 4793 & \begin{tabular}{|l|l|} 
PIPP36 \\
\end{tabular} & \begin{tabular}{|l|l|}
$7005-74$ \\
\end{tabular} & 9 & 2/161:06 0:00 & Coal & UNIT 9 - B2 & $\begin{array}{l}\text { Base line testing- - } \\
\text { uncrushed coal }\end{array}$ & 4.63 & 6.32 & 52.39 & 71.48 & 3.52 & 4.80 & 26.71 & 0.72 & 0.98 & 11.75 & 16.04 & 0.28 & 0.38 \\
\hline 4894 & \begin{tabular}{|c|c|}
475900 \\
\end{tabular} & \begin{tabular}{|l|l|}
$7005-74$ \\
\end{tabular} & 7 & 2/141/06 0:00 & Coal & UNIT 7 - A2 & Duplicate of 4759 & 4.26 & 5.77 & 52.87 & 71.55 & 3.59 & 4.86 & 26.11 & 0.69 & 0.93 & 12.22 & 16.54 & 0.26 & 0.35 \\
\hline 4895 & $\begin{array}{c}477600 \\
P\end{array}$ & \begin{tabular}{|l|l|}
$7005-74$ & \\
\end{tabular} & 8 & 2/15/06 0:00 & Coal & UNIT \& - B1 & Duplicate of 4776 & 4.43 & 6.00 & 52.52 & 71.16 & 3.59 & 4.86 & 26.19 & 0.69 & 0.93 & 12.32 & 16.70 & 0.26 & 0.35 \\
\hline 4896 & $4 \begin{array}{c}479000 \\
P\end{array}$ & \begin{tabular}{|l|l|}
$7005-74$ \\
\end{tabular} & 9 & 2/116/06 0:00 & Coal & UNIT 9 - A1 & Duplicate of 4790 & 4.19 & 5.65 & 53.53 & 72.20 & 3.57 & 4.81 & 25.86 & 0.72 & 0.97 & 11.89 & 16.04 & 0.24 & 0.33 \\
\hline
\end{tabular}




\begin{tabular}{|c|c|c|c|c|c|c|c|c|c|c|c|c|c|c|c|c|c|c|c|}
\hline ADA ID & Field ID & Project & Unit & Date & Type & Location & Comments & $\begin{array}{l}\% \text { Ash } \\
\text { (as rec) }\end{array}$ & $\begin{array}{l}\% \text { Ash } \\
\text { (dry) }\end{array}$ & $\begin{array}{c}\% \mathrm{FC} \\
(\text { as rec) }\end{array}$ & $\begin{array}{l}\% \mathrm{FC} \\
(\mathrm{dry})\end{array}$ & $\begin{array}{l}\% \mathrm{H} 2 \mathrm{O} \\
(\text { a r rec) }\end{array}$ & $\begin{array}{c}\% \mathrm{~s} \\
\text { (as rec) }\end{array}$ & $\begin{array}{l}\% S \\
\text { (dry) }\end{array}$ & $\begin{array}{l}\% \text { Vol } \\
(\text { as rec) }\end{array}$ & $\begin{array}{c}\% \mathrm{Vol} \\
(\mathrm{dry}) \\
\end{array}$ & $\begin{array}{l}\text { BTU/b } \\
\text { (as rec) }\end{array}$ & $\begin{array}{l}\text { BTU/b } \\
\text { (dry) }\end{array}$ & $\begin{array}{c}\begin{array}{c}\text { MAF } \\
\text { (BTU/b) }\end{array} \\
\end{array}$ \\
\hline 4758 & \begin{tabular}{|l|} 
PIPP1 \\
\end{tabular} & $7005-74$ & 7 & 2/14/06 0:00 & Coal & UNIT 7 - A1 & $\begin{array}{l}\text { Basel line esting - } \\
\text { uncrushed coal }\end{array}$ & 4.29 & 5.84 & 38.50 & 52.43 & 26.56 & 0.26 & 0.35 & 30.65 & 41.73 & 9014 & 12274 & 13035 \\
\hline 4759 & \begin{tabular}{|l|l|} 
PIPP2 \\
\end{tabular} & $7005-74$ & 7 & 2/14/06 0:00 & Coal & UNIT 7 - A2 & $\begin{array}{l}\text { Basel line esting - } \\
\text { uncrushed coaal }\end{array}$ & 4.16 & 5.68 & 38.61 & 52.69 & 26.72 & 0.29 & 0.40 & 30.51 & 41.63 & 9047 & 12346 & 13089 \\
\hline 4760 & PIPP3 & $7005-74$ & 7 & \begin{tabular}{|l|l|}
$2 / 14 / 0600: 00$ \\
\end{tabular} & Coal & UNIT 7 - B1 & $\begin{array}{l}\text { Basel line esting - } \\
\text { uncrushed coal }\end{array}$ & 4.61 & 6.26 & 38.70 & 52.58 & 26.40 & 0.26 & 0.35 & 30.29 & 41.16 & 9012 & 12245 & 13063 \\
\hline 4761 & \begin{tabular}{|l|l|} 
PIPP4 \\
\end{tabular} & 7005-74 & 7 & 2/144/06 0:00 & Coal & UNIT 7 - B2 & $\begin{array}{l}\text { Basel line testing - } \\
\text { uncrushed coal }\end{array}$ & 4.86 & 6.66 & 38.01 & 52.10 & 27.05 & 0.28 & 0.39 & 30.08 & 41.24 & 8863 & 12149 & 13016 \\
\hline 4762 & \begin{tabular}{|l|} 
PIPP5 \\
\end{tabular} & \begin{tabular}{|l|l|}
$7005-74$ \\
\end{tabular} & 8 & \begin{tabular}{|l|l|}
$2 / 14 / 06$ & $0: 00$ \\
\end{tabular} & Coal & UNIT 8-A1 & $\begin{array}{l}\text { Base iline lesting- - } \\
\text { uncrushed coal }\end{array}$ & 4.62 & 6.29 & 38.60 & 52.50 & 26.48 & 0.28 & 0.38 & 30.30 & 41.21 & 9071 & 12338 & 13166 \\
\hline 4763 & \begin{tabular}{|l|l|} 
PIPP6 \\
\end{tabular} & \begin{tabular}{ll|}
$7005-74$ \\
\end{tabular} & 8 & 2/14/006 0:00 & Coal & UNIT 8 - A2 & $\begin{array}{l}\text { Base line lessing - } \\
\text { uncrushed coal }\end{array}$ & 4.44 & 6.04 & 38.44 & 52.35 & 26.56 & 0.26 & 0.35 & 30.56 & 41.61 & 9031 & 12297 & 13087 \\
\hline 4764 & \begin{tabular}{|l|l|} 
PIPP7 \\
\end{tabular} & 7005-74 & 8 & \begin{tabular}{|l|l|} 
2/14/006 0:00 \\
\end{tabular} & Coal & UNIT 8 - B1 & $\begin{array}{l}\text { Base line testing- - } \\
\text { uncrushed coal }\end{array}$ & 4.68 & 6.42 & 38.04 & 52.20 & 27.12 & 0.26 & 0.36 & 30.16 & 41.38 & 8879 & 12183 & 13019 \\
\hline 4765 & PIPP8 & 7005-74 & 8 & 2/14/006 0:00 & Coal & UNIT 8 - B2 & $\begin{array}{l}\text { Base line lessing- - } \\
\text { uncrushed coal }\end{array}$ & 4.62 & 6.28 & 38.31 & 52.03 & 26.38 & 0.27 & 0.36 & 30.69 & 41.69 & 8996 & 12220 & 13039 \\
\hline 4766 & PIPP9 & 7005-74 & 9 & 2/14/06 0:00 & Coal & UNIT 9 - A1 & $\begin{array}{l}\text { Base line tessting- - } \\
\text { uncrushed coal }\end{array}$ & 4.69 & 6.36 & 38.62 & 52.42 & 26.31 & 0.26 & 0.35 & 30.38 & 41.22 & 8980 & 12186 & 13014 \\
\hline 4767 & PIPP10 & $7005-74$ & 9 & 2/14/006 0:00 & Coal & UNIT 9 - A2 & $\begin{array}{l}\text { Base line lesting- - } \\
\text { uncrushed coal }\end{array}$ & 5.16 & 6.94 & 38.58 & 51.84 & 25.59 & 0.29 & 0.39 & 30.67 & 41.22 & 8995 & 12088 & 12989 \\
\hline 4768 & PIPP11 & 7005-74 & 9 & 2/14/006 0:00 & Coal & UNIT 9 - B1 & $\begin{array}{l}\text { Base lilene lesting- - } \\
\text { uncrushed coal }\end{array}$ & 4.44 & 6.07 & 38.32 & 52.33 & 26.78 & 0.26 & 0.36 & 30.46 & 41.60 & 8942 & 12212 & 13001 \\
\hline 4769 & PIPP12 & 7005-74 & 9 & 2/14/006 0:00 & Coal & UNIT 9 - B2 & $\begin{array}{l}\text { Base line tessing- - } \\
\text { uncrushed coal }\end{array}$ & 4.41 & 6.04 & 38.32 & 52.42 & 26.91 & 0.26 & 0.35 & 30.36 & 41.54 & 8947 & 12241 & 13028 \\
\hline 4770 & PIPP13 & 7005-74 & 7 & 2/15/06 0:00 & Coal & UNIT 7 - A1 & $\begin{array}{l}\text { Base line testitig- } \\
\text { uncrushhed coal }\end{array}$ & 4.57 & 6.23 & 38.24 & 52.16 & 26.68 & 0.26 & 0.36 & 30.51 & 41.61 & 8968 & 12231 & 13044 \\
\hline 4771 & PIPP14 & 7005-74 & 7 & 2/15/006 0:00 & Coal & UNIT 7 - A2 & $\begin{array}{l}\text { Base line testitig- } \\
\text { uncrushed coal }\end{array}$ & 4.23 & 5.75 & 38.74 & 52.65 & 26.42 & 0.27 & 0.37 & 30.61 & 41.60 & 9080 & 12340 & 13093 \\
\hline 4772 & PIPP15 & 7005-74 & 7 & 2/15/06 0:00 & Coal & UNIT 7 - B1 & $\begin{array}{l}\text { Baseline esting - } \\
\text { uncrushed coal }\end{array}$ & 4.45 & 6.06 & 38.45 & 52.33 & 26.52 & 0.27 & 0.37 & 30.58 & 41.61 & 9021 & 12277 & 13069 \\
\hline 4773 & \begin{tabular}{|l|l|} 
PIPP16 \\
\end{tabular} & 7005-74 & 7 & 2/15/106 0:00 & Coal & UNIT 7 - B2 & $\begin{array}{l}\text { Basel line esting - } \\
\text { uncrushed coal }\end{array}$ & 4.40 & 6.00 & 38.50 & 52.52 & 26.70 & 0.26 & 0.35 & 30.40 & 41.48 & 8993 & 12269 & 13052 \\
\hline 4774 & PIPP17 & \begin{tabular}{|l|l|}
$7005-74$ \\
\end{tabular} & 8 & \begin{tabular}{|l|l|}
$2 / 15 / 060: 000$ \\
\end{tabular} & Coal & UNIT 8-A1 & $\begin{array}{l}\text { Base line esting - } \\
\text { uncrushed coal }\end{array}$ & 4.49 & 6.09 & 38.57 & 52.36 & 26.33 & 0.27 & 0.37 & 30.61 & 41.55 & 9061 & 12299 & 13097 \\
\hline 4775 & \begin{tabular}{|l|l|} 
PIPP 18 \\
\end{tabular} & \begin{tabular}{|l|l|}
$7005-74$ \\
\end{tabular} & 8 & 2/15/106 0:00 & Coal & UNIT 8 - A2 & $\begin{array}{l}\text { Base line testing- - } \\
\text { uncrushed coal }\end{array}$ & 4.81 & 6.53 & 38.50 & 52.28 & 26.36 & 0.27 & 0.36 & 30.33 & 41.19 & 9009 & 12234 & 13089 \\
\hline 4776 & PIPP19 & \begin{tabular}{|l|l|}
$7005-74$ \\
\end{tabular} & 8 & 2/115/06 0:00 & Coal & UNIT 8 - B1 & $\begin{array}{l}\text { Base line esting - } \\
\text { uncrushed coal }\end{array}$ & 5.10 & 6.86 & 38.42 & 51.67 & 25.64 & 0.27 & 0.36 & 30.84 & 41.47 & 9108 & 12249 & 13151 \\
\hline 4777 & PIPP20 & \begin{tabular}{ll|}
$7005-74$ \\
\end{tabular} & 8 & 2/15/06 0:00 & Coal & UNIT 8 - B2 & $\begin{array}{l}\text { Base line lesting - } \\
\text { uncrushed coal }\end{array}$ & 4.76 & 6.55 & 38.04 & 52.40 & 27.39 & 0.28 & 0.39 & 29.81 & 41.05 & 8865 & 12209 & 13065 \\
\hline 4778 & PIPP21 & \begin{tabular}{|l|l|}
$7005-74$ \\
\end{tabular} & 9 & 2/15/06 0:00 & Coal & UNIT 9 - A1 & $\begin{array}{l}\text { Bases line testing- } \\
\text { uncrushed coal }\end{array}$ & 4.93 & 6.68 & 38.58 & 52.32 & 26.26 & 0.29 & 0.40 & 30.23 & 41.00 & 9037 & 12255 & 13132 \\
\hline 4779 & PIPP22 & $7005-74$ & 9 & 2/15/06 0:00 & Coal & UNIT 9 - A2 & $\begin{array}{l}\text { Base line lesting- } \\
\text { uncrushed coal }\end{array}$ & 4.35 & 6.00 & 38.04 & 52.53 & 27.57 & 0.25 & 0.34 & 30.04 & 41.47 & 8855 & 12226 & 13006 \\
\hline 4780 & PIPP23 & \begin{tabular}{|l|l|}
$7005-74$ \\
\end{tabular} & 9 & \begin{tabular}{|l|}
$2 / 15 / 06$ \\
\end{tabular} & Coal & UNIT 9 - B1 & $\begin{array}{l}\text { Base line esting - } \\
\text { uncrushed coala }\end{array}$ & 4.52 & 6.12 & 38.83 & 52.57 & 26.13 & 0.28 & 0.38 & 30.52 & 41.31 & 9102 & 12321 & 13124 \\
\hline 4781 & PIPP24 & $7005-74$ & 9 & 2/15/06 0:00 & Coal & UNIT 9 - B2 & $\begin{array}{l}\text { Basel line testing - } \\
\text { uncrushed coaal }\end{array}$ & 4.40 & 6.06 & 38.26 & 52.64 & 27.33 & 0.26 & 0.36 & 30.01 & 41.30 & 8917 & 12271 & 13063 \\
\hline 4782 & PIPP25 & 7005-74 & 7 & 2/16/106 0:00 & Coal & UNIT 7 - A1 & $\begin{array}{l}\text { Base line tessing- - } \\
\text { uncrushed coal }\end{array}$ & 4.58 & 6.19 & 38.62 & 52.23 & 26.02 & 0.24 & 0.32 & 30.75 & 41.58 & 9055 & 12245 & 13053 \\
\hline 4783 & PIPP26 & $7005-74$ & 7 & 2/16/06 0:00 & Coal & UNIT 7 - A2 & $\begin{array}{l}\text { Base line testing- - } \\
\text { unnorushed coal }\end{array}$ & 4.11 & 5.56 & 39.10 & 52.89 & 26.07 & 0.27 & 0.36 & 30.72 & 41.55 & 9124 & 12342 & 13069 \\
\hline 4784 & PIPP27 & 7005-74 & 7 & 2/16/06 0:00 & Coal & UNIT 7 - B1 & $\begin{array}{l}\text { Baseline esting - } \\
\text { uncrushed coal }\end{array}$ & 4.72 & 6.35 & 38.66 & 52.06 & 25.73 & 0.27 & 0.36 & 30.89 & 41.59 & 9115 & 12273 & 13105 \\
\hline 4785 & \begin{tabular}{|l|l|} 
PIPP28 \\
\end{tabular} & 7005-74 & 7 & 2/16/106 0:00 & Coal & UNIT 7 - B2 & $\begin{array}{l}\text { Base line } \\
\text { uncrush }\end{array}$ & 4.16 & 5.66 & 38.54 & 52.47 & 26.55 & 0.26 & 0.35 & 30.75 & 41.87 & 8992 & 12243 & 12978 \\
\hline 4786 & PIPP29 & \begin{tabular}{|l|l|}
$7005-74$ \\
\end{tabular} & 8 & \begin{tabular}{|l|l|}
$2 / 16 / 106$ & $0: 00$ \\
\end{tabular} & Coal & UNIT 8-A1 & $\begin{array}{l}\text { Base line esting - } \\
\text { uncrushed coaal }\end{array}$ & 4.87 & 6.58 & 38.41 & 51.86 & 25.94 & 0.27 & 0.37 & 30.78 & 41.56 & 9081 & 12262 & 13126 \\
\hline 4787 & PIPP30 & \begin{tabular}{|l|l|}
$7005-74$ \\
\end{tabular} & 8 & 2/16/06 0:00 & Coal & UNIT 8 - A2 & $\begin{array}{l}\text { Base line lessing- - } \\
\text { uncrushed coal }\end{array}$ & 4.74 & 6.43 & 38.42 & 52.07 & 26.22 & 0.29 & 0.39 & 30.62 & 41.50 & 8997 & 12195 & 13033 \\
\hline 4788 & PIPP31 & \begin{tabular}{|l|l|}
$7005-74$ \\
\end{tabular} & 8 & 2/16/06 0:00 & Coal & UNIT 8 - B1 & $\begin{array}{l}\text { Base line testing- } \\
\text { uncrushed coal }\end{array}$ & 4.54 & 6.20 & 38.31 & 52.32 & 26.77 & 0.26 & 0.36 & 30.38 & 41.48 & 8990 & 12277 & 13088 \\
\hline 4789 & PIPP32 & \begin{tabular}{|l|l|}
$7005-74$ \\
\end{tabular} & 8 & 2/116/06 0:00 & Coal & UNIT 8 - B2 & $\begin{array}{l}\text { Base line testing - } \\
\text { uncrushed coal }\end{array}$ & 4.97 & 6.83 & 37.66 & 51.70 & 27.17 & 0.27 & 0.37 & 30.20 & $\begin{array}{lll}41.47 \\
\end{array}$ & 8834 & 12130 & 13019 \\
\hline 4790 & PIPP33 & $7005-74$ & 9 & 2/16/06 0:00 & Coal & UNIT 9 - A1 & $\begin{array}{l}\text { Base line esting - } \\
\text { uncrushed coaal }\end{array}$ & 4.58 & 6.27 & 38.23 & 52.34 & 26.96 & 0.28 & 0.38 & 30.23 & 41.39 & 8961 & 12268 & 13089 \\
\hline 4791 & PIPP34 & $7005-74$ & 9 & 2/16/06 0:00 & Coal & UNIT 9 - A2 & $\begin{array}{l}\text { Base lir } \\
\text { uncru }\end{array}$ & 4.94 & 6.74 & 38.05 & 51.94 & 26.73 & 0.28 & 0.38 & 30.28 & 41.32 & 8817 & 12034 & 12904 \\
\hline 4792 & \begin{tabular}{|l|l|} 
PIPP35 \\
\end{tabular} & \begin{tabular}{|l|l|}
$7005-74$ \\
\end{tabular} & 9 & \begin{tabular}{|l|}
$2 / 16 / 060: 00$ \\
\end{tabular} & Coal & UNIT 9 - B1 & $\begin{array}{l}\text { Base line esting - } \\
\text { uncrushed coala }\end{array}$ & 4.35 & 5.97 & 38.42 & 52.67 & 27.06 & 0.28 & 0.39 & 30.17 & 41.36 & 8972 & 12300 & 13081 \\
\hline 4793 & \begin{tabular}{|l|l|} 
PIPP 36 \\
\end{tabular} & $7005-74$ & 9 & 2/16/06 0:00 & Coal & UNIT 9 - B2 & $\begin{array}{l}\text { Base line testing- - } \\
\text { uncrushed coal }\end{array}$ & 4.63 & 6.32 & 38.38 & 52.36 & 26.71 & 0.28 & 0.38 & 30.28 & 41.32 & 8955 & 12219 & 13043 \\
\hline 4894 & $\underset{P}{47590 U}$ & 7005-74 & 7 & \begin{tabular}{|l|l|}
$2 / 14 / 06$ & $0: 00$ \\
\end{tabular} & Coal & UNIT 7 - A2 & Duplicate of 4759 & 4.26 & 5.77 & 38.86 & 52.59 & 26.11 & 0.26 & 0.35 & 30.77 & 41.64 & 9076 & 12283 & 13035 \\
\hline 4895 & $\begin{array}{l}4776 \mathrm{DU} \\
\mathrm{P}\end{array}$ & $7005-74$ & 8 & 2/15/06 0:00 & Coal & UNIT 8 - B1 & Duplicate of 4776 & 4.43 & 6.00 & 38.60 & 52.30 & 26.19 & 0.26 & 0.35 & 30.78 & 41.70 & 9030 & 12234 & 13015 \\
\hline 4896 & $\underset{p}{4790 D U}$ & 7005-74 & 9 & 2/16/06 0:00 & Coal & UNIT 9 - A1 & Duplicate of 4790 & 4.19 & 5.65 & 39.09 & 52.73 & 25.86 & 0.24 & 0.33 & 30.86 & 41.62 & 9206 & 12417 & 13161 \\
\hline
\end{tabular}




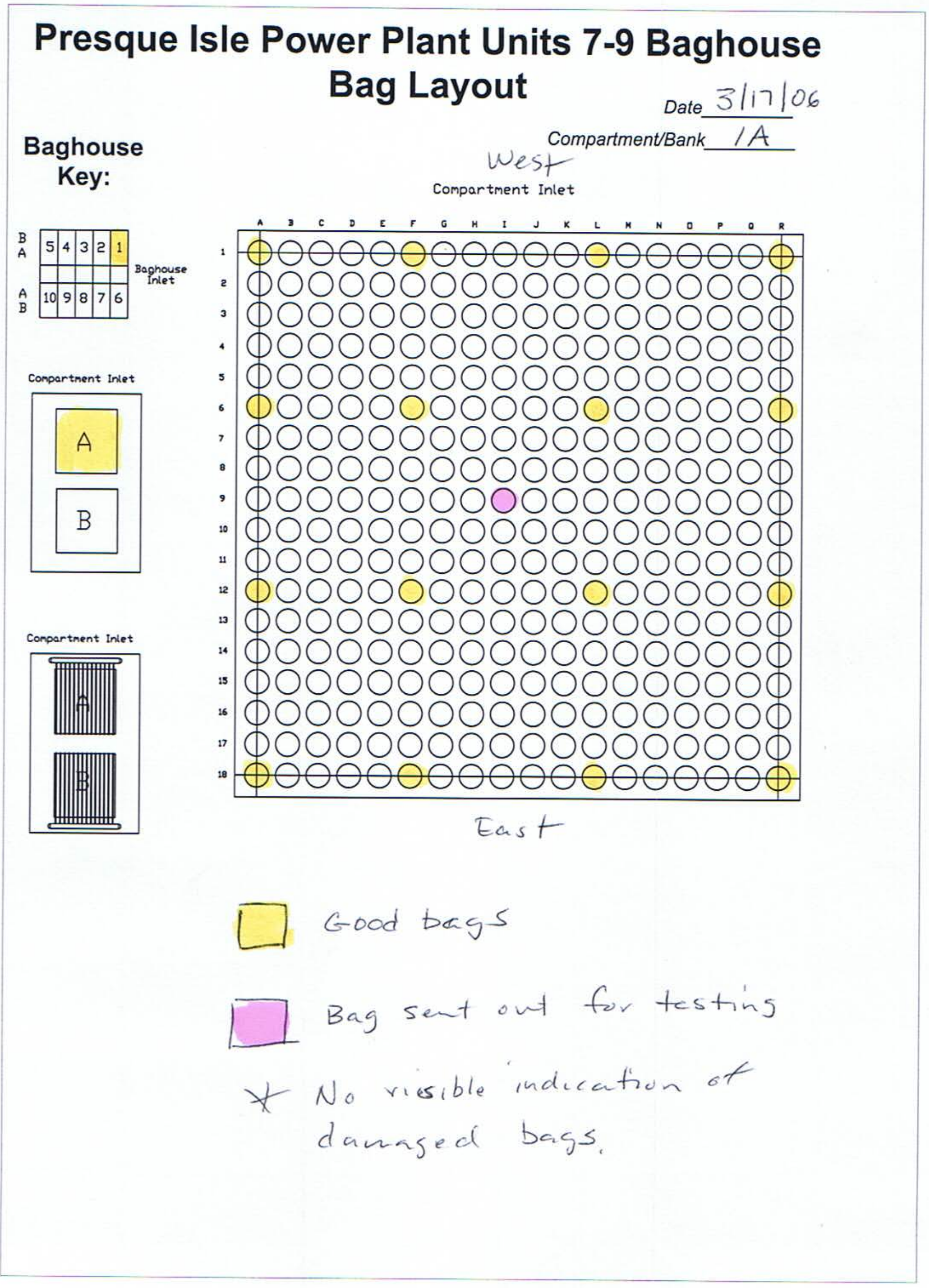




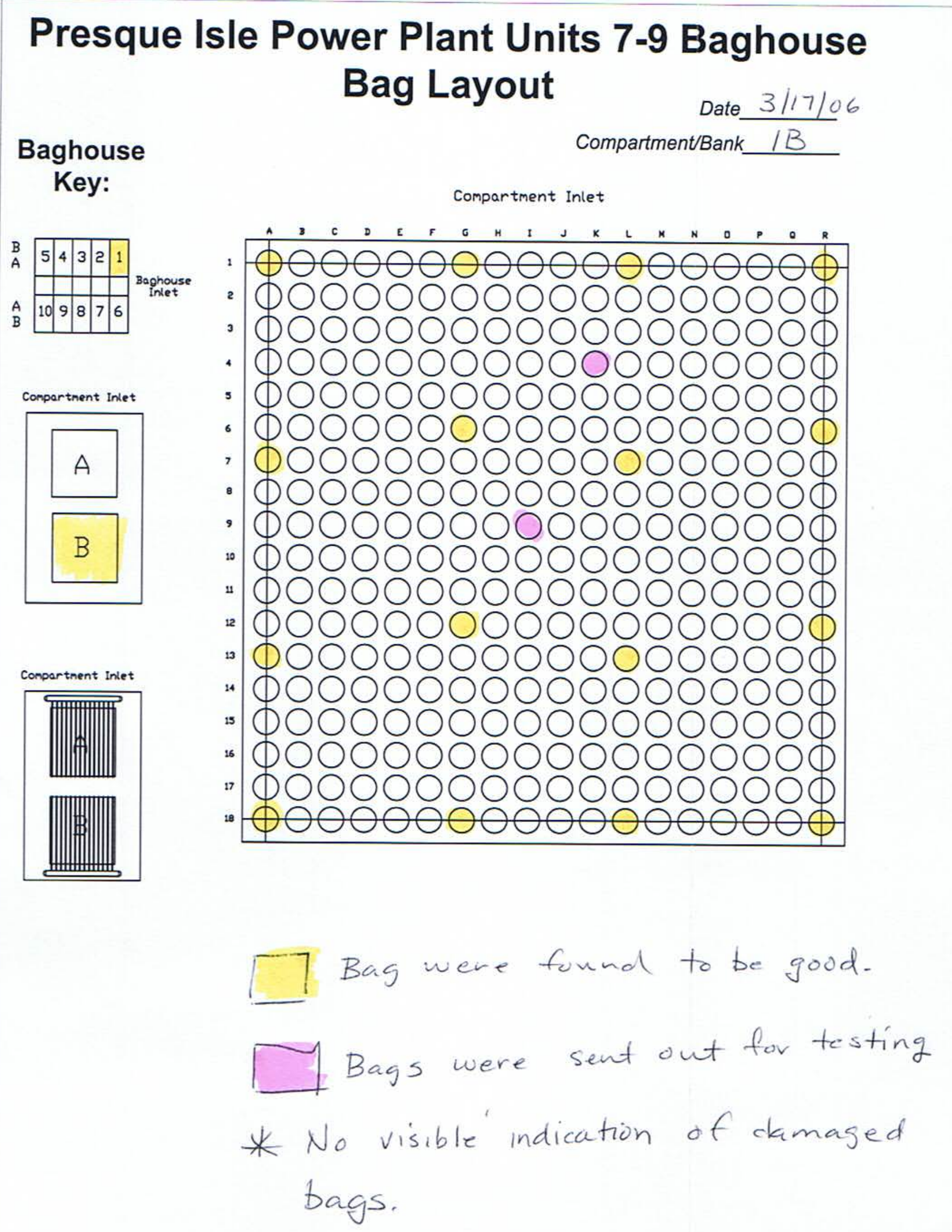




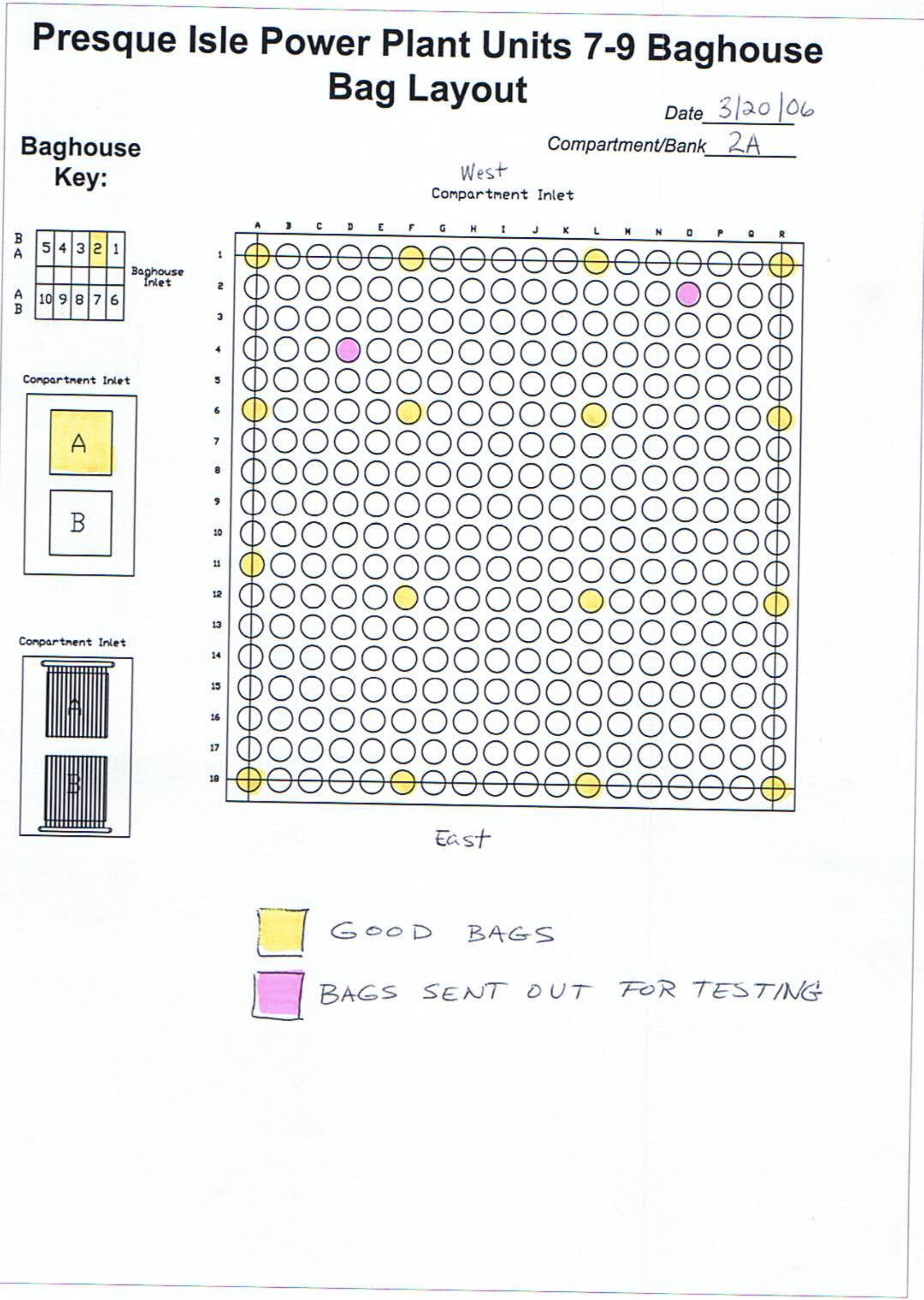




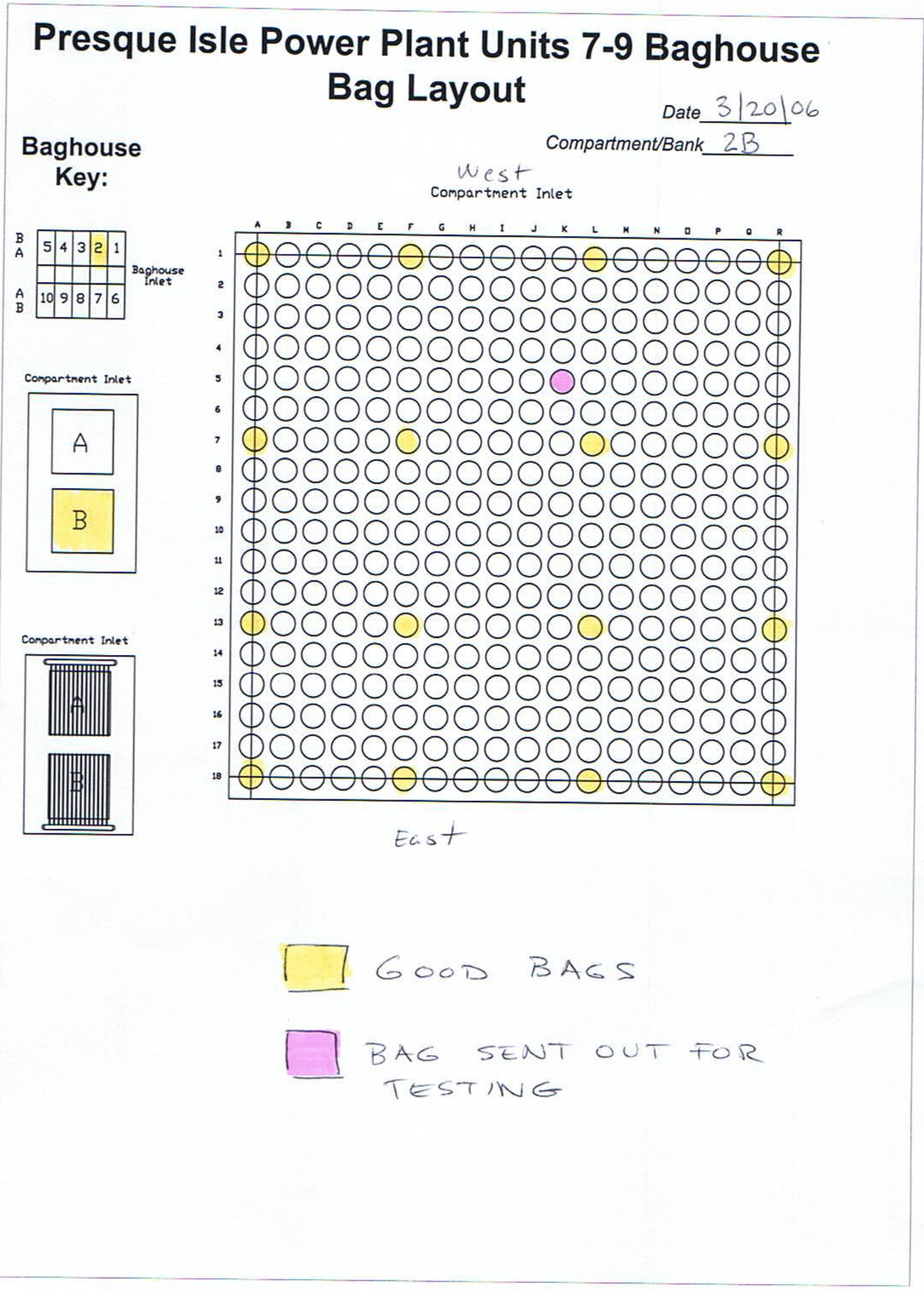




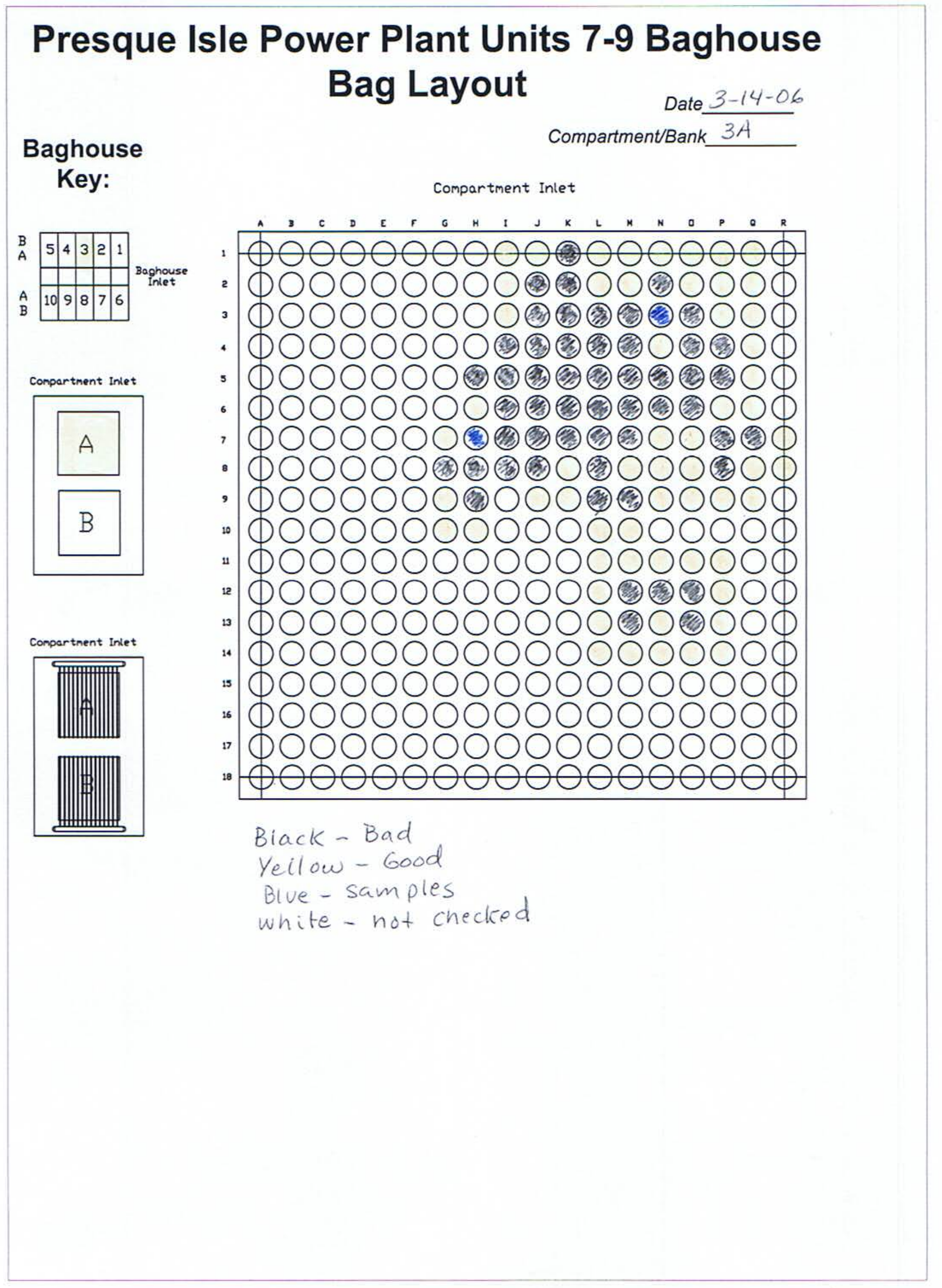




\section{Presque Isle Power Plant Units 7-9 Baghouse Bag Layout \\ Baghouse

\author{
Date 3-17-06
} \\ Compartment/Bank 3 B}

Key:

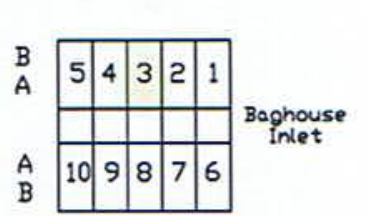

Compartment Inlet

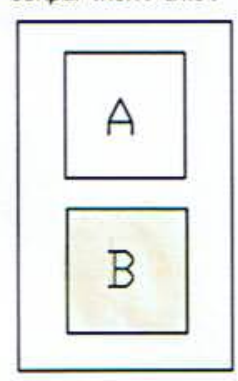

Compartment Inlet

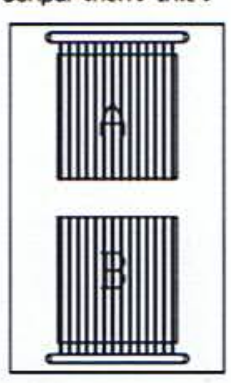

Compartment Inlet

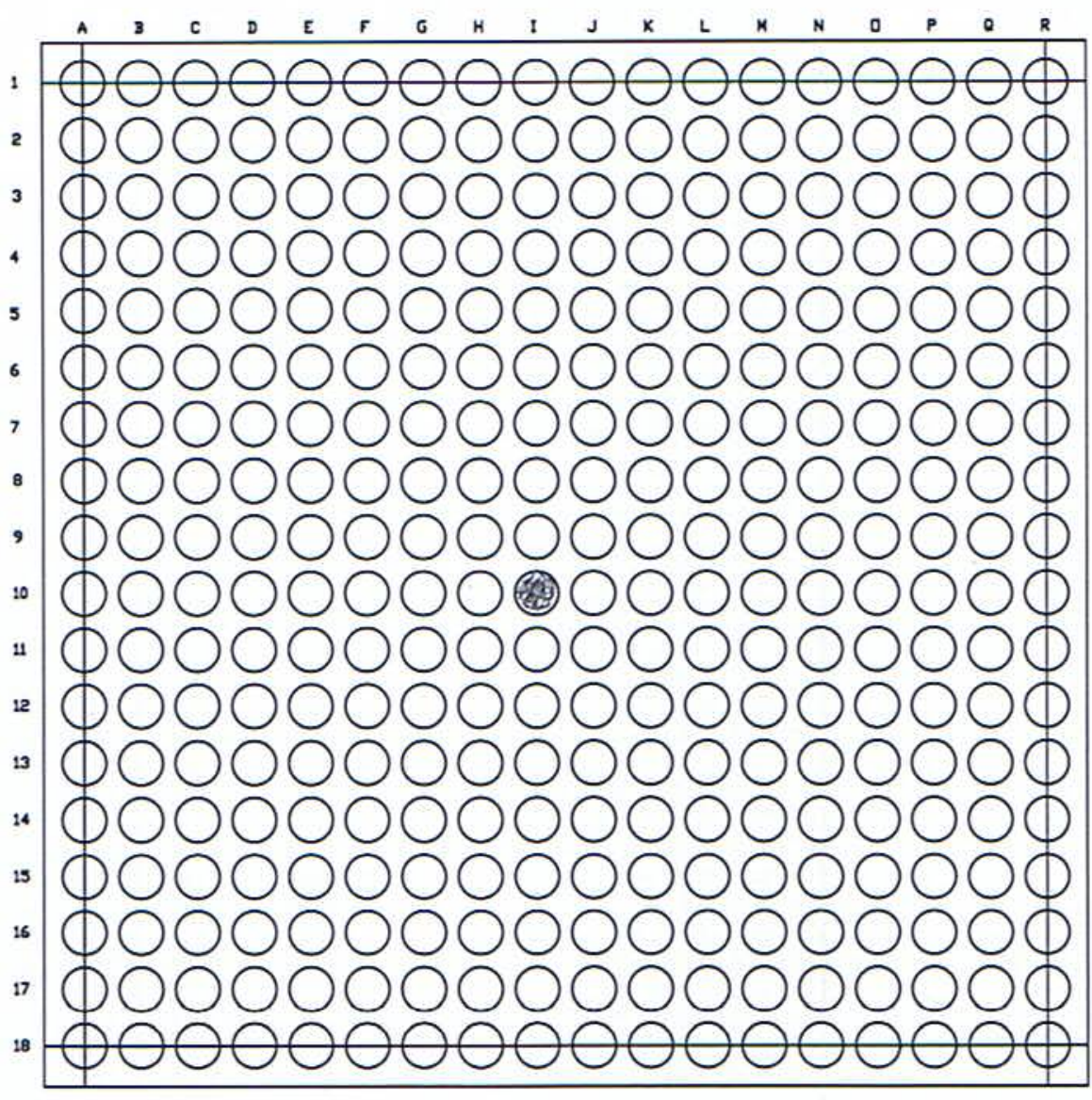

$3 B I 10$ was inissing bag and bottom section of cage. Some bags were found to have smaller diameter collars than others. Samples to be sent out. 


\section{Presque Isle Power Plant Units 7-9 Baghouse Bag Layout \\ Baghouse \\ Key: \\ Compartment/Bank $4 A$ \\ Compartment Inlet}
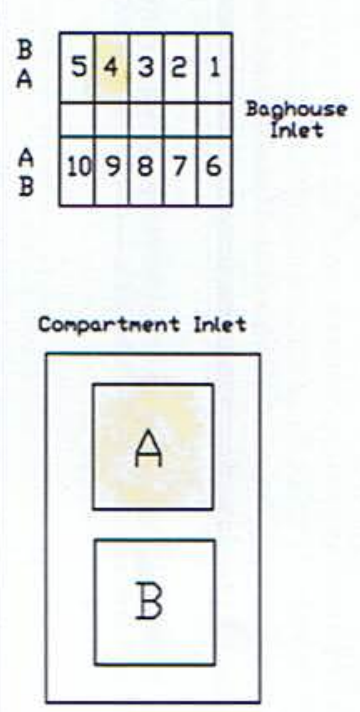

Compartment Inlet

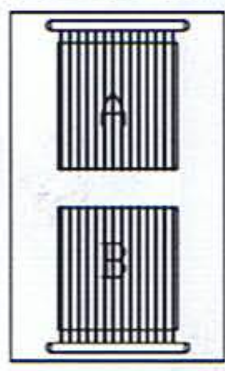

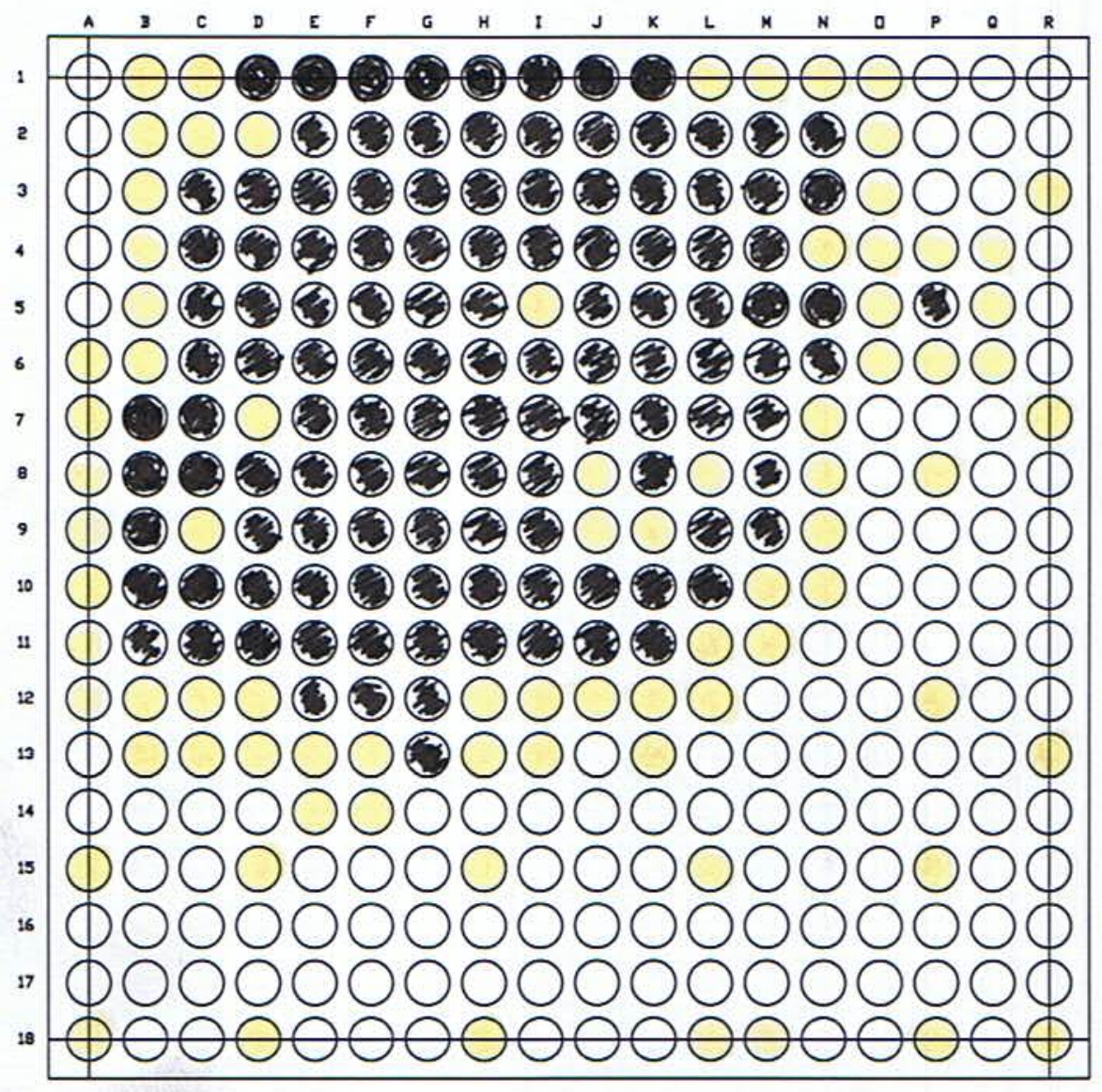

Samples:

$4 A 5 M$ Burnt bottom

4A6M Burnt/split up the seann $4 A 9 M$ Burnt/splut up the seam

4A $2 M$ Bunnt bottom

4A BD Crisp bottom

$4 A 4 C$ crisp cuft at bottom

$4 A T C$ Crisp cuff at bottom 


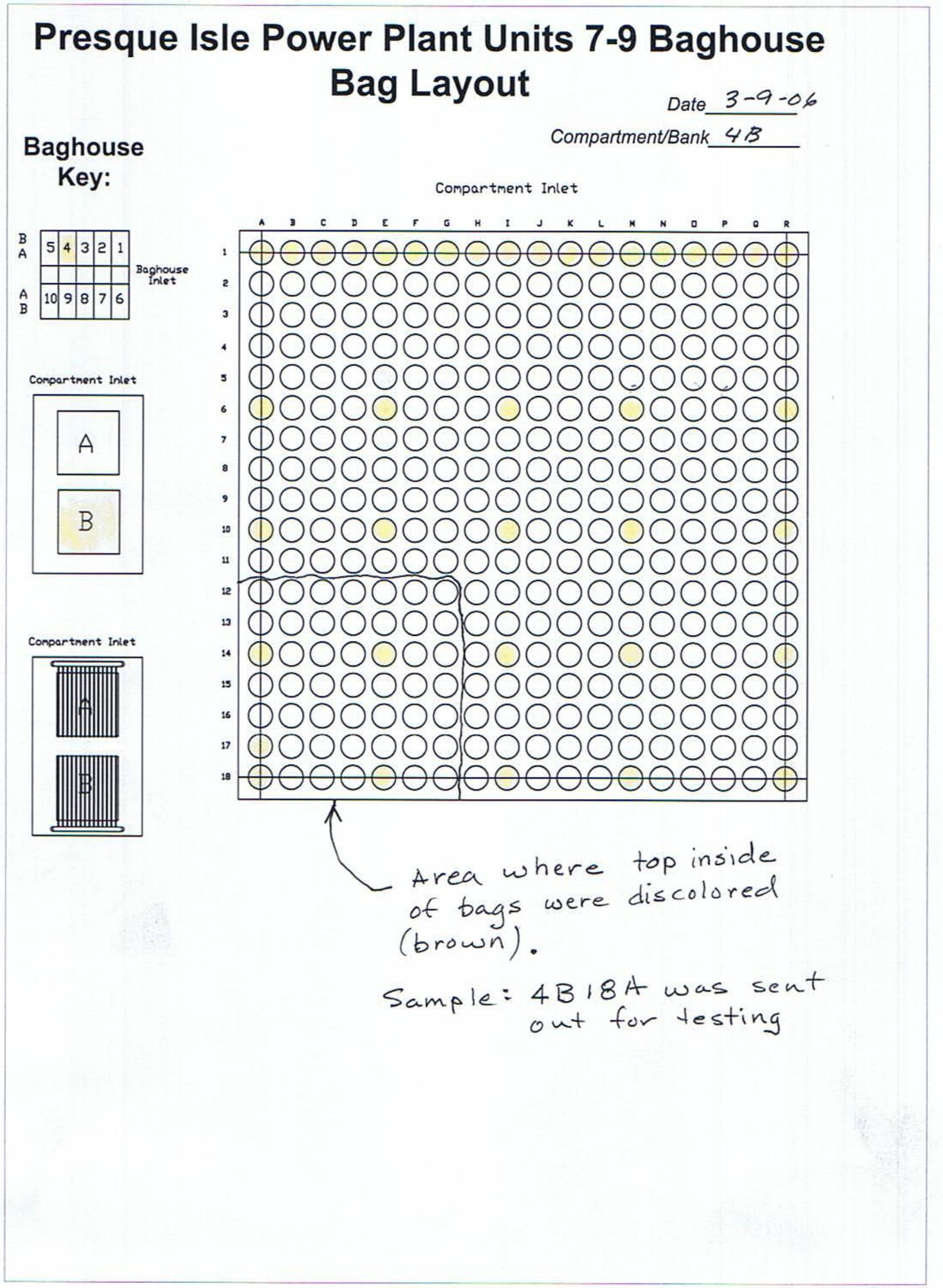




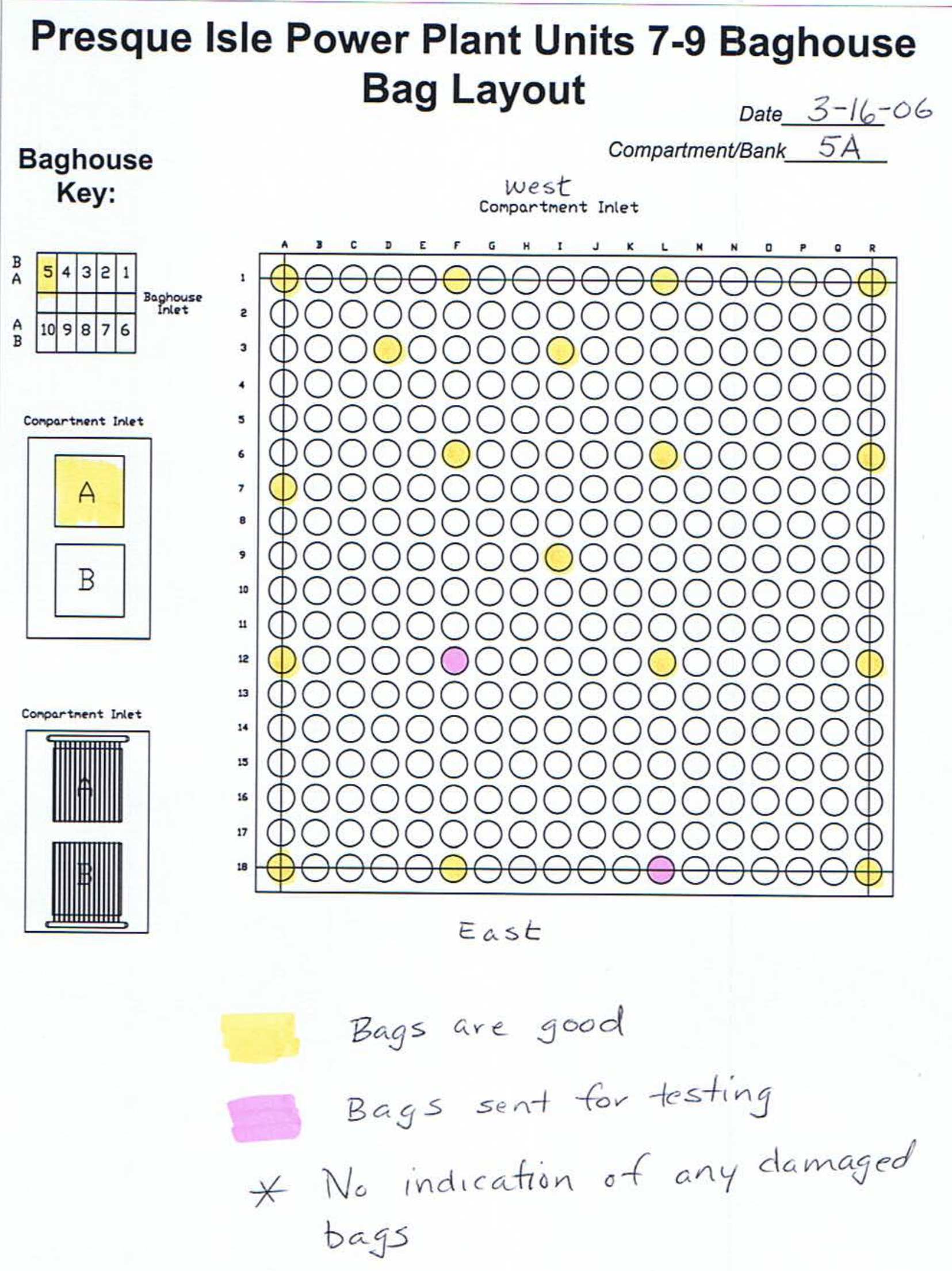




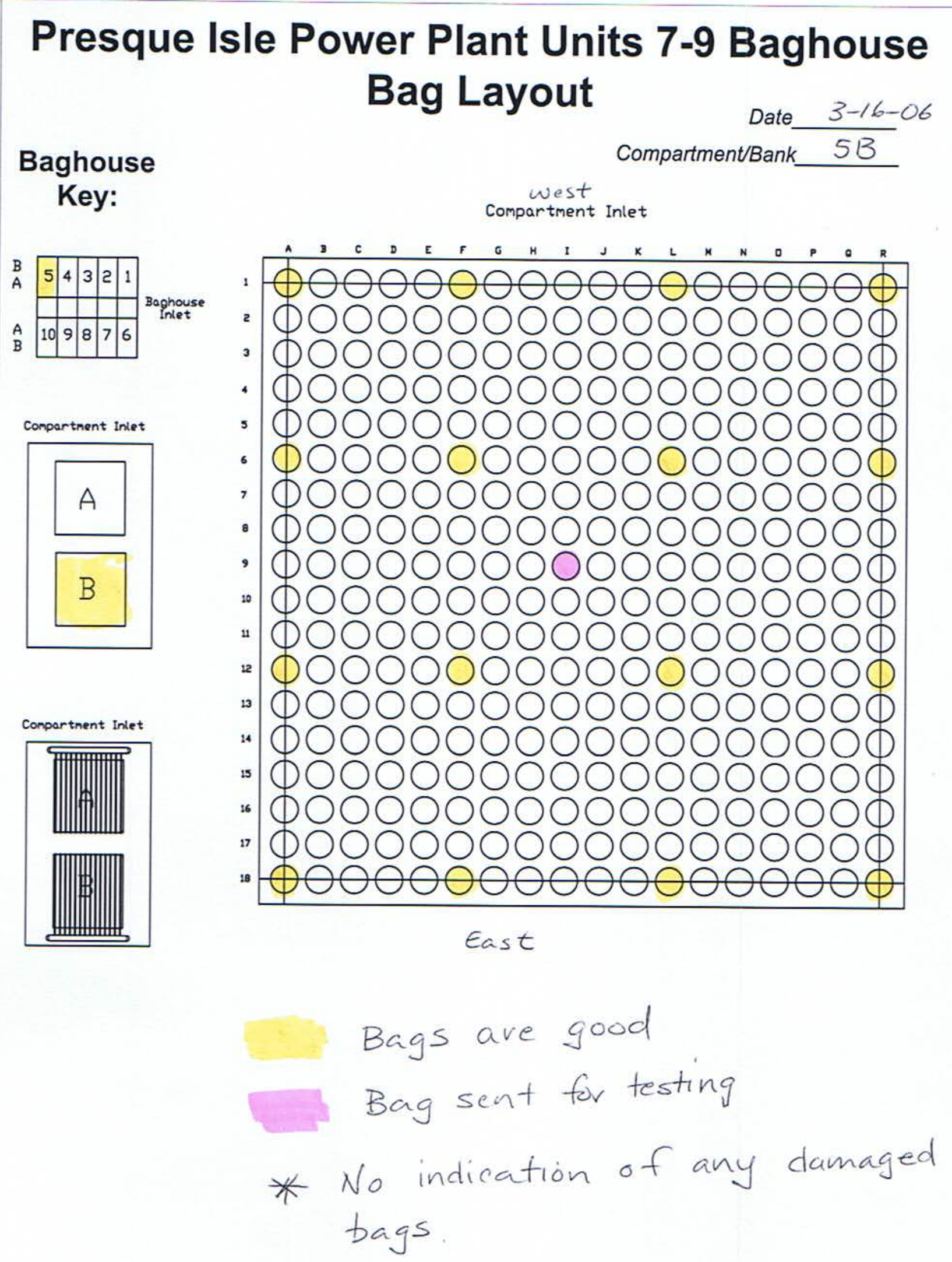




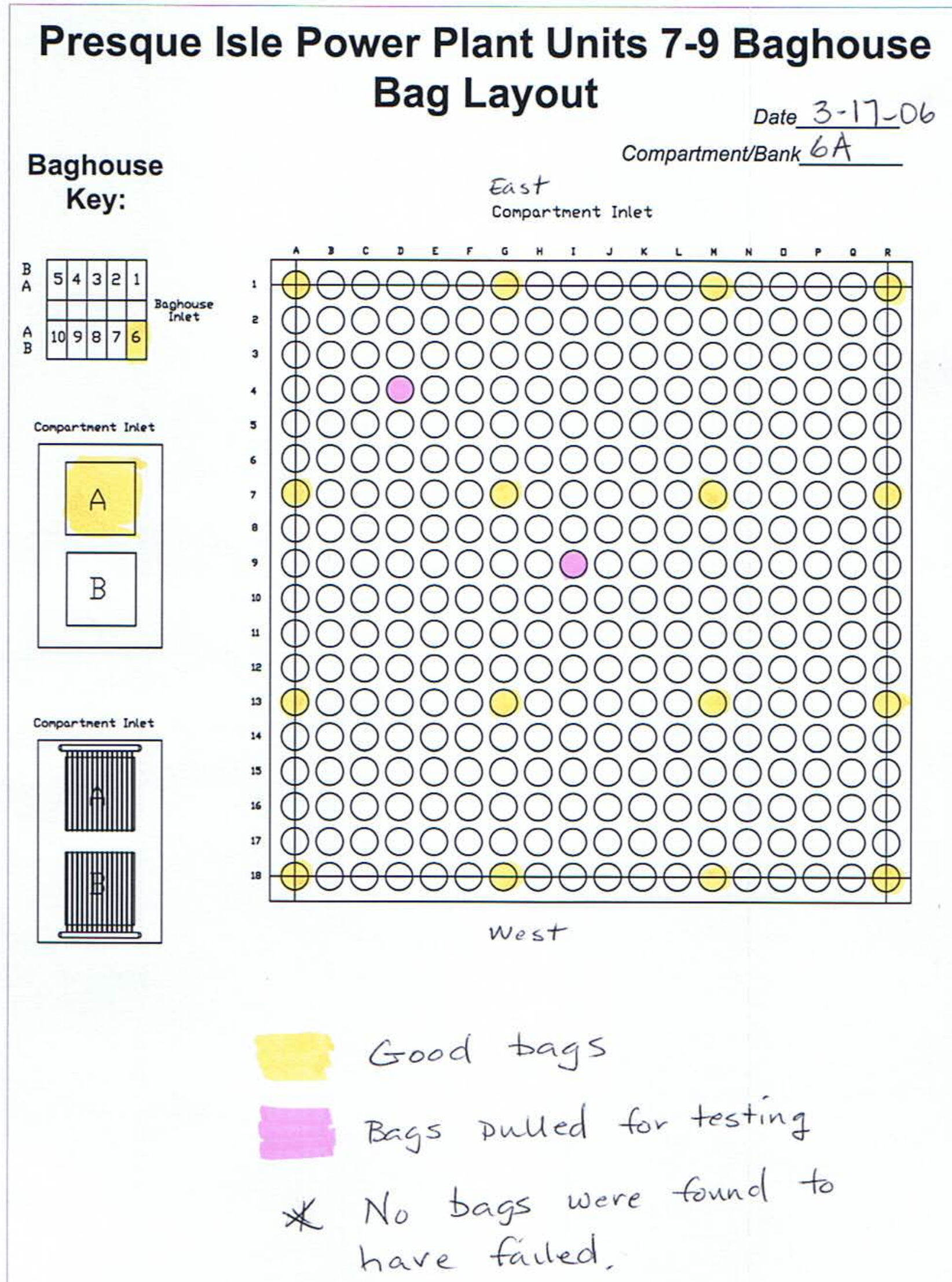




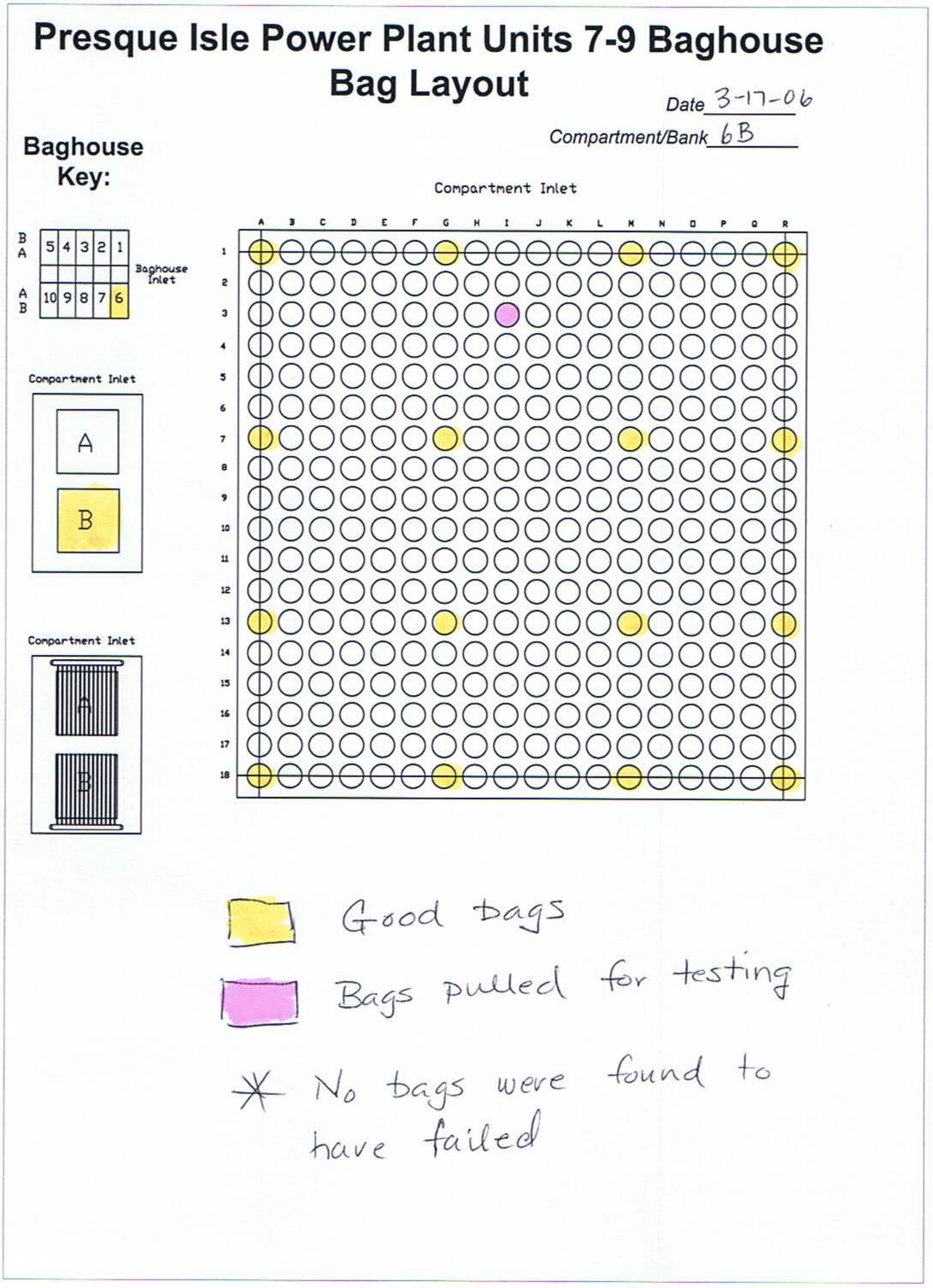




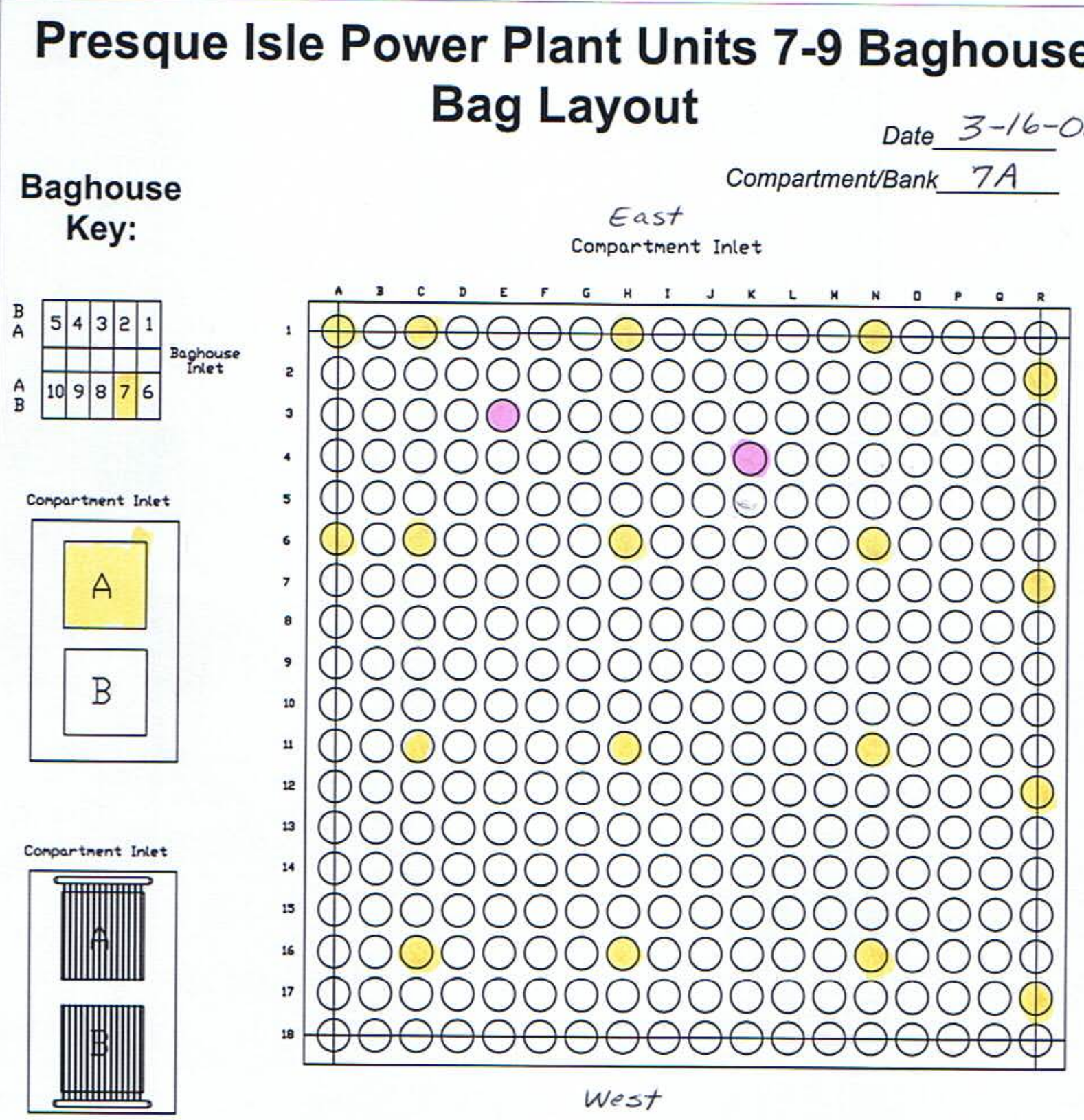

Yellow-sood

pink - samples

* No fárled bags identified 


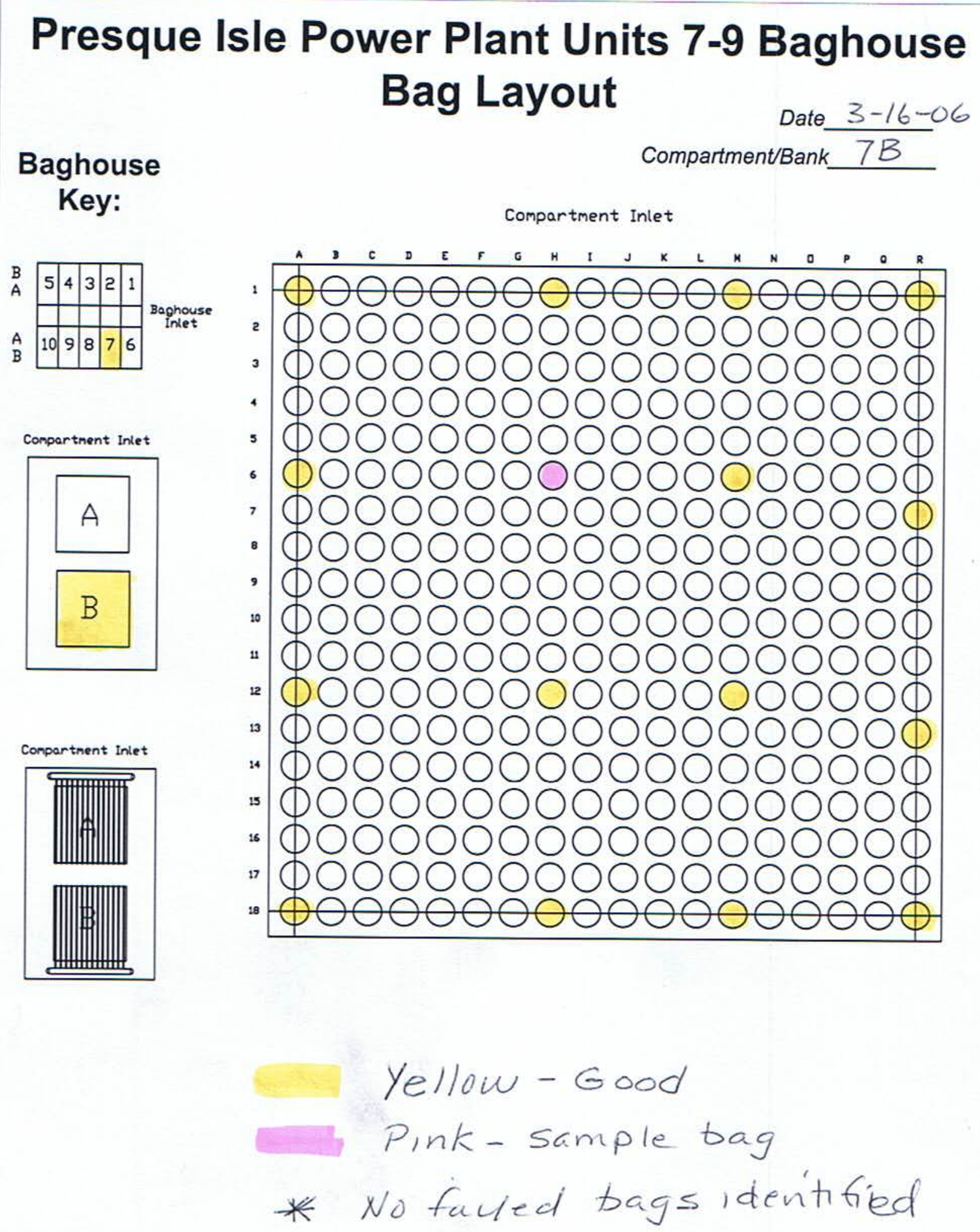




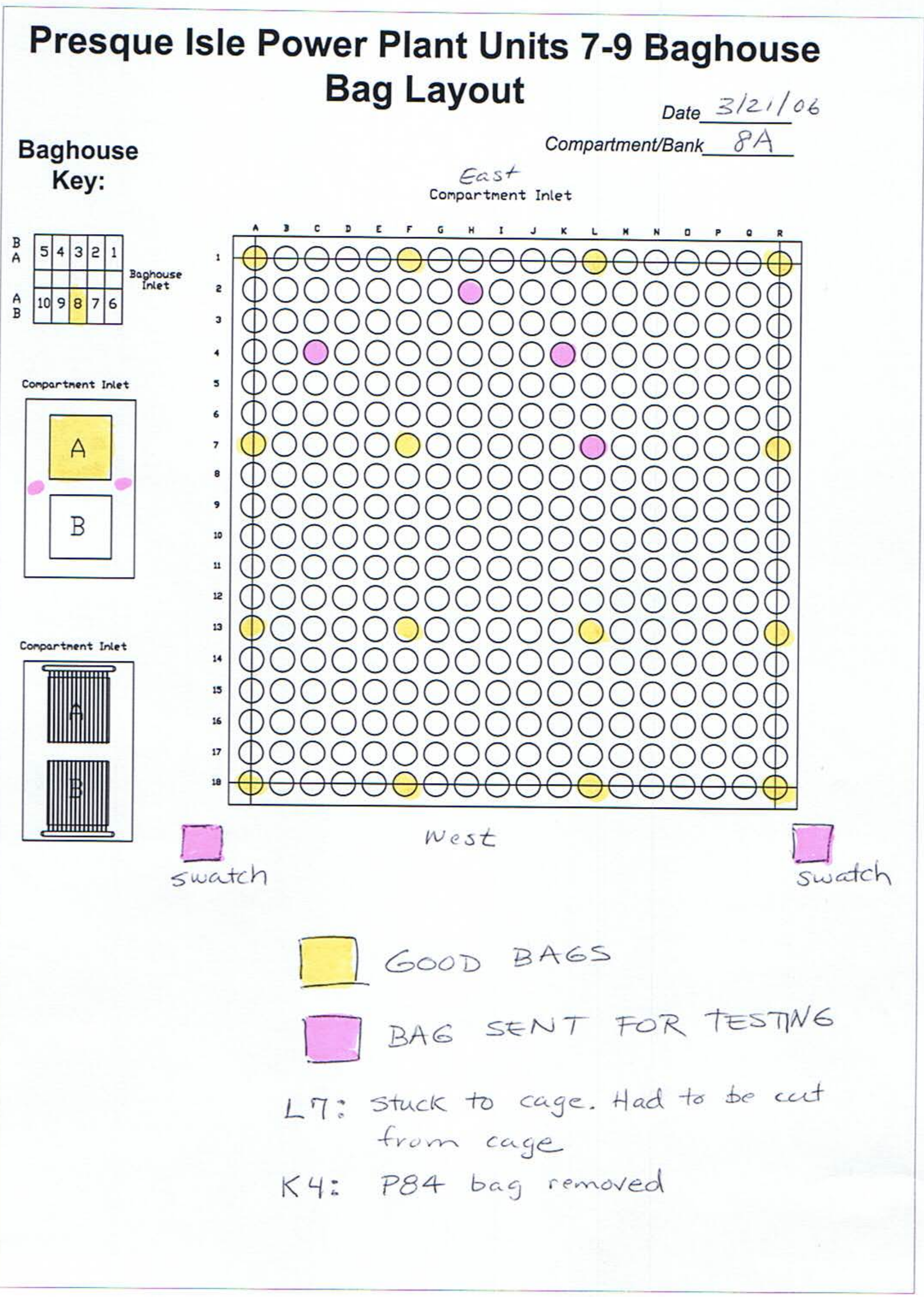




\section{Presque Isle Power Plant Units 7-9 Baghouse Bag Layout \\ Baghouse \\ Key:

Compartment/Bank $3 / 21 / 06$ \\ Compartment Inlet}
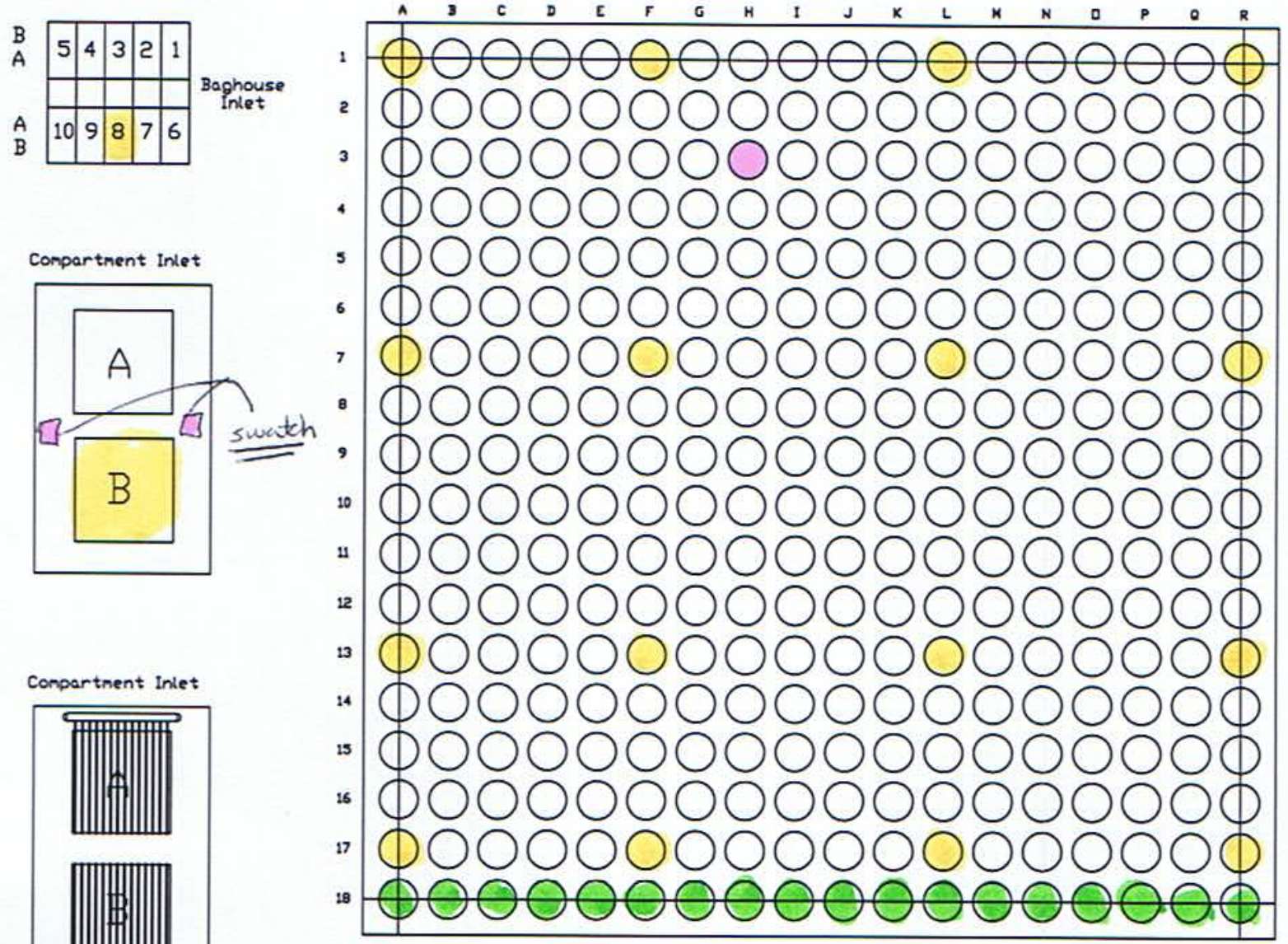

Compartment Inlet

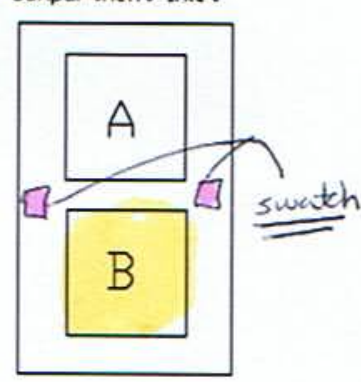

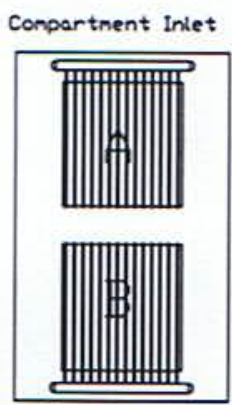

GOOD BAGS

BAG SENT FOR TESTING

Row 18 stiff-conid not pull out because of moisture/corrosion. 


\section{Presque Isle Power Plant Units 7-9 Baghouse Bag Layout \\ Baghouse Key: \\ East \\ Compartment Inlet}

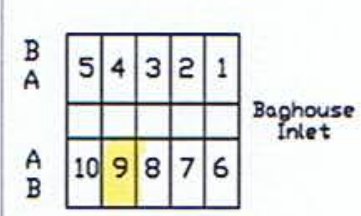

Compartment Inlet

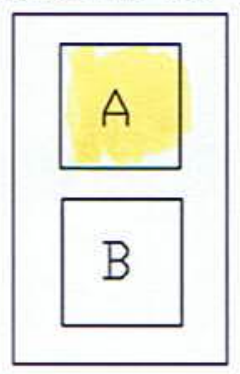

Compartment Inlet

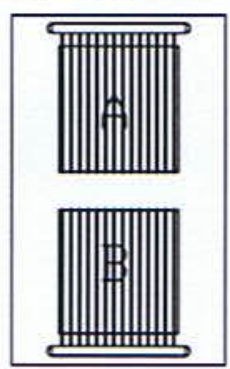

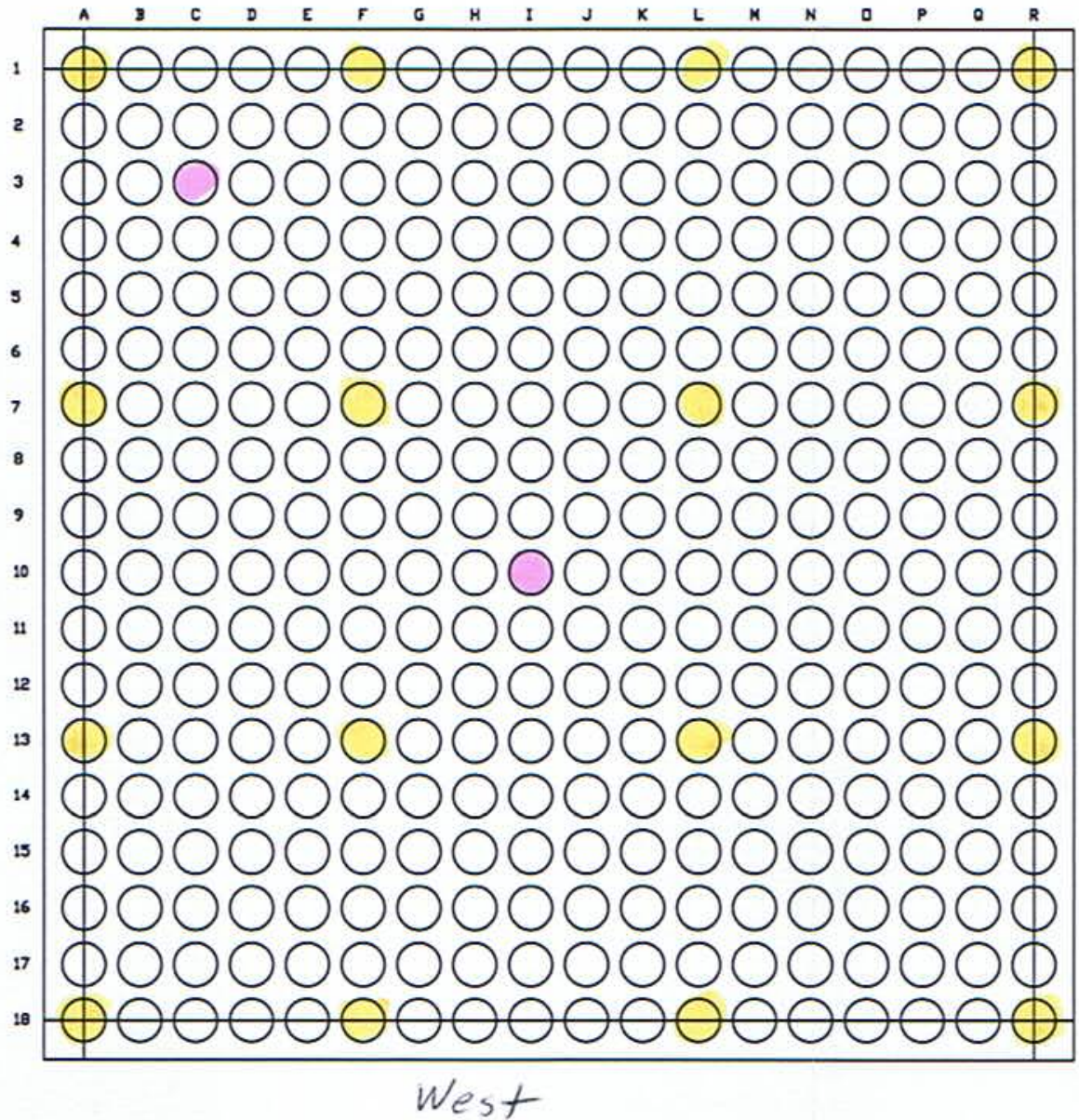

Good bags

Bags sent fo be tested

* No indication of bad bags. 
Presque Isle Power Plant Units 7-9 Baghouse Bag Layout

Date 3/20/06

Bughouse

Compartment/Bank $9 B$. Key:

East
Compartment Inlet
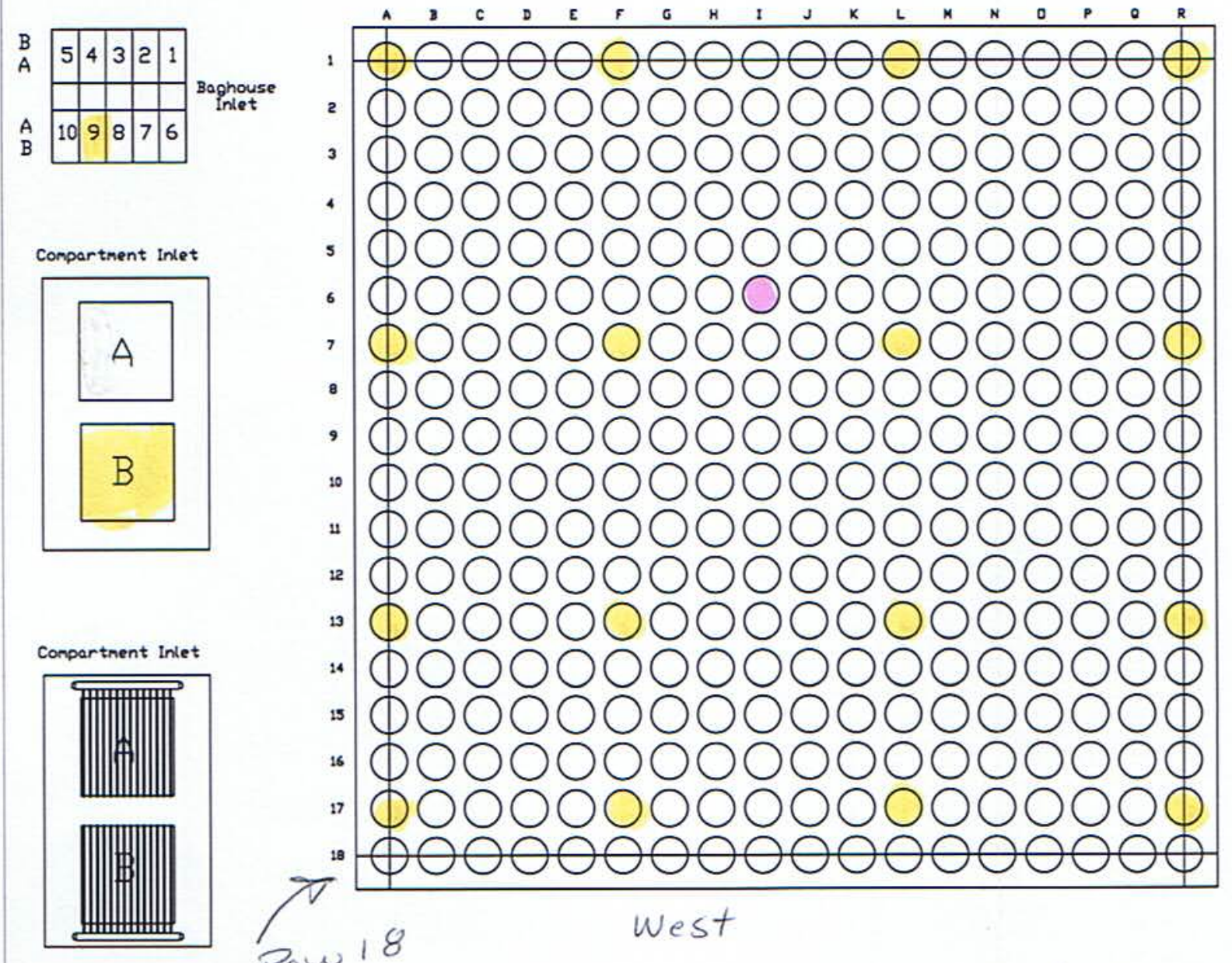

. 100000000000000000

: 100000000000000000

- $\$ 00000000000000000$

, $\$ 00000000000000001$

- $\$ 00000000000000000$

- $\$ 00000000000000000$

- $\$ 00000000000000000$

" $\$ 00000000000000000$

: 100000000000000000

- 100000000000000000

" $\$ 00000000000000000$

: $\$ 00000000000000000$

" $\$ 00000000000000000$

:

$\pi$

west

Row 18

$\square$ Bags were found to be good

Bag sent out for sampling

* No indication of bat bags

Bow 18 cages were difficult to lift from tags. Appears to be caused by "J" tube condensate. 


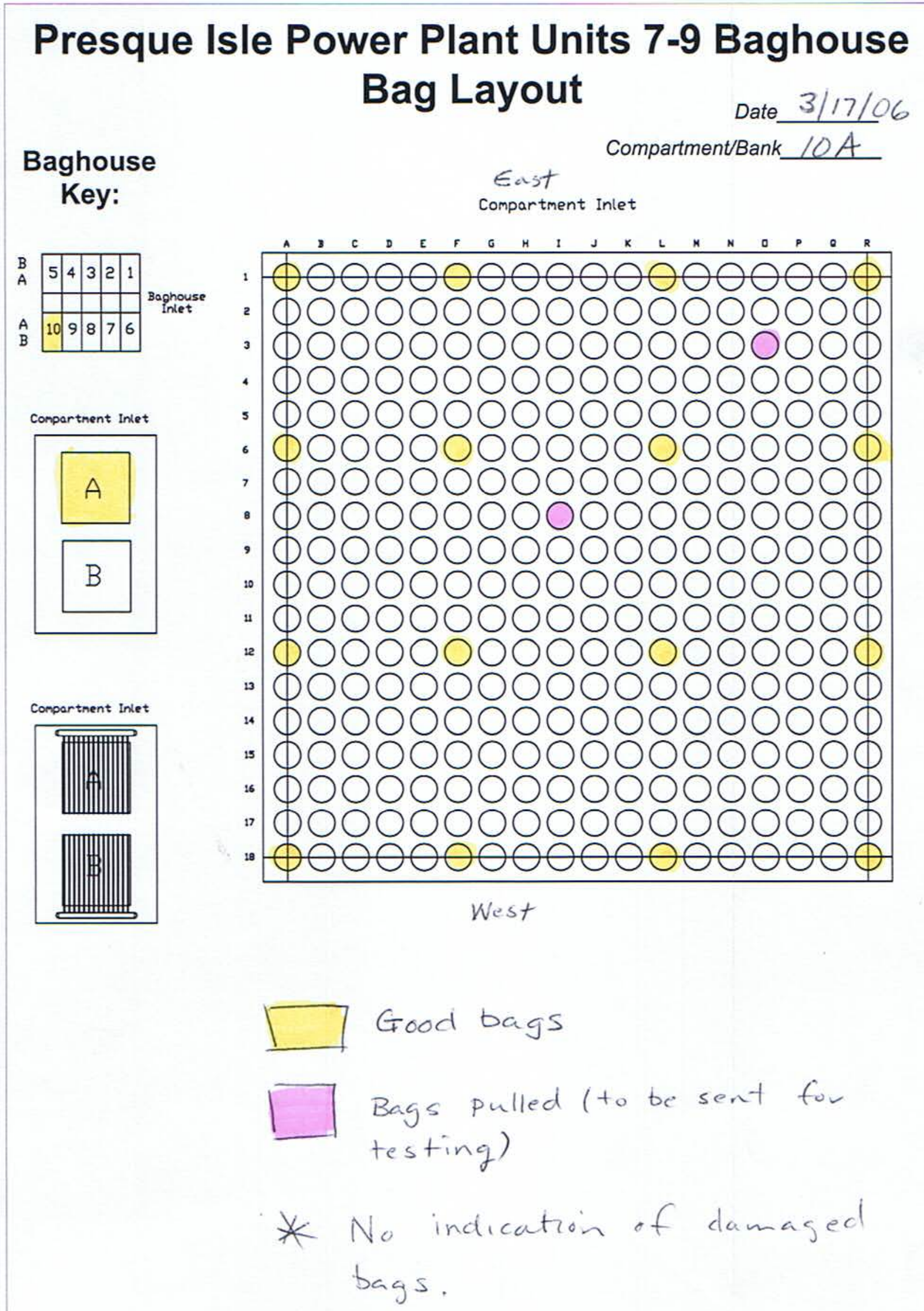




\section{Presque Isle Power Plant Units 7-9 Baghouse Bag Layout \\ Baghouse \\ Key:

\author{
Date $3 / 17 / 06$
} \\ Compartment/Bank $10 B$ \\ East}

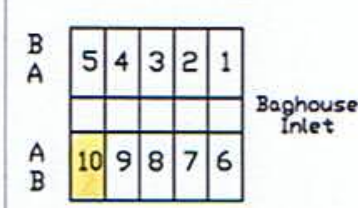

Compartment Inlet

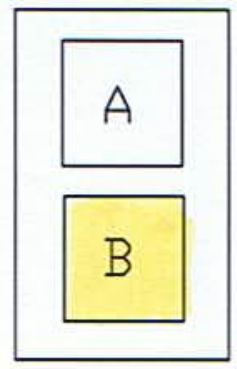

Compartment Inlet

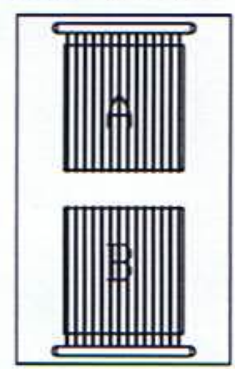

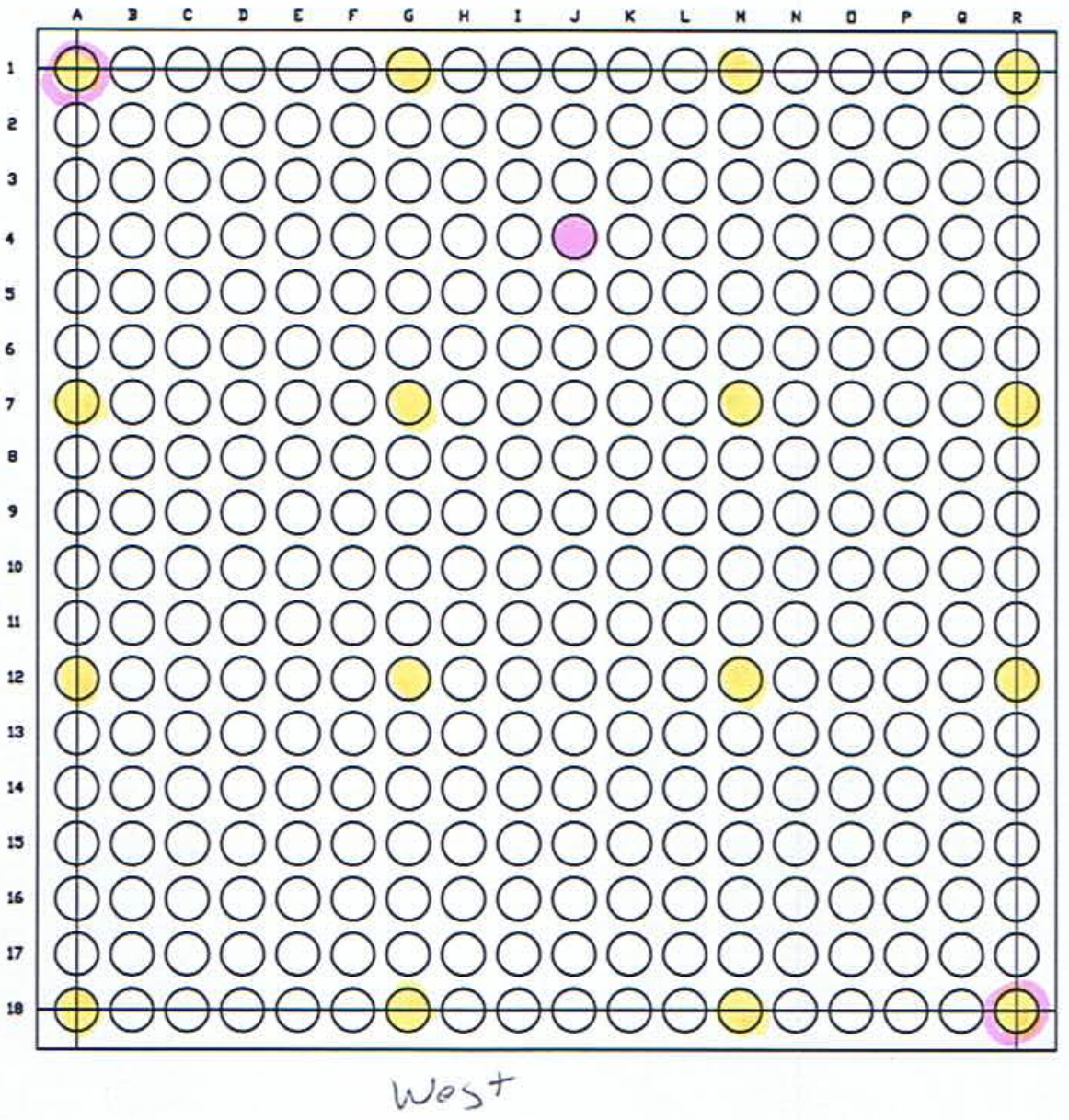

Good bags

Bag sent out for testing Bags were replaced because cages were separated and the only way to remove cage was to cut the bag.

Note: Rows 10-18 cages were real tight to inside of bags. 


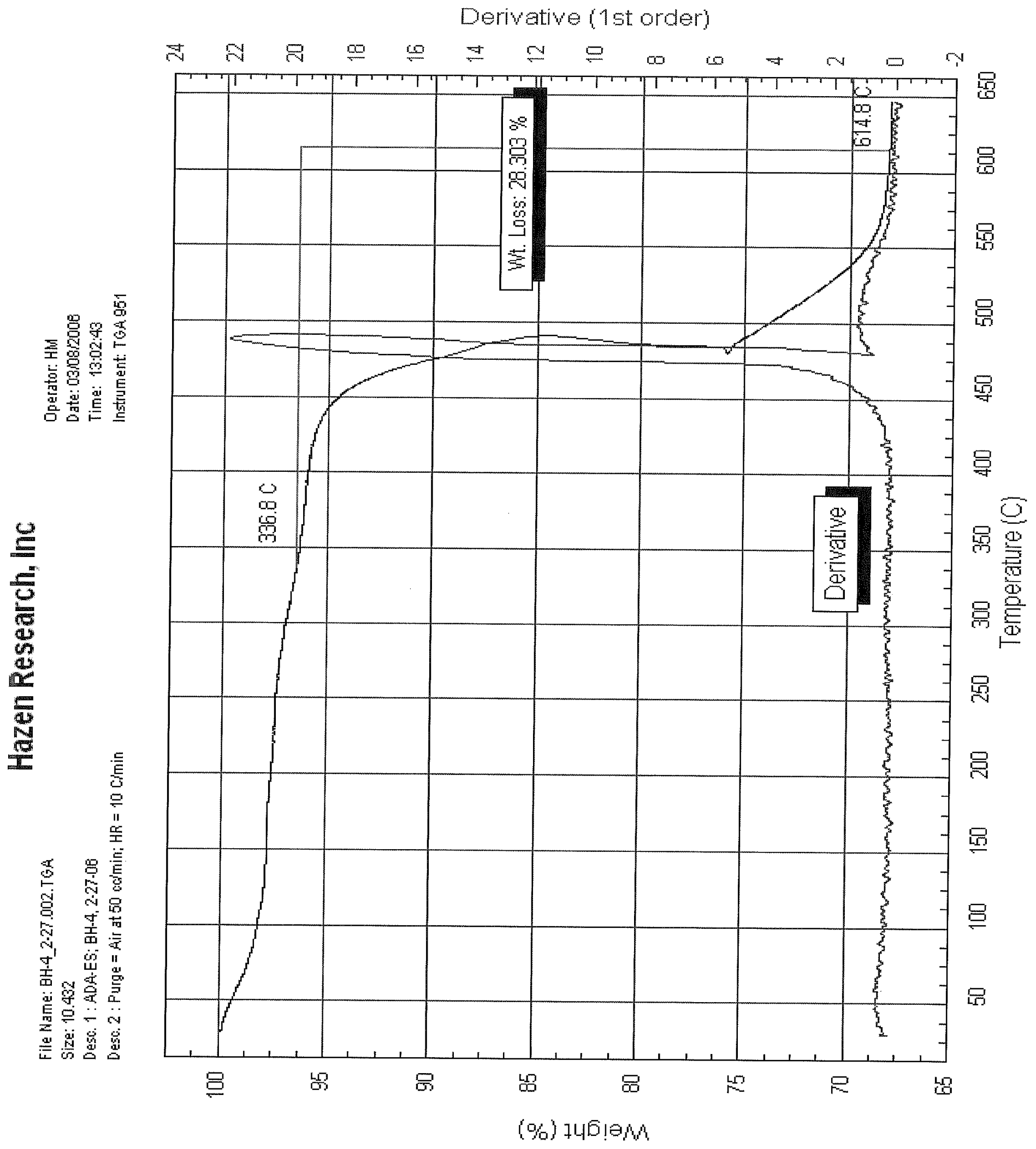


